\title{
Words Without Meaning: The Constitution, Confessions, and Mentally Retarded Suspects
}

\author{
Morgan Cloud $\dagger$ \\ George B. Shepherd $\dagger \dagger$ \\ Alison Nodvin Barkoff $\dagger \dagger$

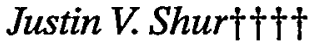

The Supreme Court's Miranda decision rested upon the unverified assumptions that suspects who received the now-famous warnings not only would possess information ensuring that subsequent waivers were "knowing and intelligent," but also would possess the tools necessary to resist the pressures inherent in custodial interrogation, thus ensuring that confessions were "voluntary." The flaws in these assumptions are exposed when they are applied to mentally retarded people. The authors of this Article tested a sample of mentally retarded individuals to determine if they could understand the Miranda wamings, then compared these results to those obtained for a control group of nondisabled people. The results show that, in contrast to the nondisabled controls, mentally retarded people simply do not understand the warnings. They do not understand the context in which interrogation occurs, the legal consequences of confessing, the meaning of the sentences comprising the warnings, or even the warnings' individual words. For mentally retarded people, the Miranda warnings are words without meaning.

\section{RIGHTS, WARNINGS, AND CONSTITUTIONAL FAILURES}

Miranda has survived. Chief Justice Rehnquist's surprising opinion for the Court in Dickerson $v$ United States ${ }^{2}$ affirmed that

$\dagger$ Charles Howard Candler Professor of Law, Emory University.

i† Associate Professor of Law, Emory University.

If $\dagger$ Attorney, Civil Division, United States Department of Justice. The views expressed in this article are those of the authors and not of the Department of Justice.

Ift' Assistant District Attorney, New York City.

We thank Thomas K. Clancy, Thomas Y. Davies, John J. Donohue III, Donald A. Dripps, Yale Kamisar, Marc L. Miller, Thomas D. Morgan, Jeffrey J. Rachlinski, Christopher Slobogin, George C. Thomas III, and the participants in faculty seminars at the University of Tennessee School of Law and Emory University School of Law for helpful comments. We are grateful to the Atlanta Alliance on Developmental Disabilities, Resources and Residential Alternatives, the Developmental Disabilities Department of the Marcus Jewish Community Center, and Annandale Village for helping us solicit volunteers for this project. Of course, we greatly appreciate the help of the volunteers themselves. We also thank Ellen Y. Chung and Christopher Bly for excellent research assistance.

1 Miranda v Arizona, 384 US 436 (1966).

2530 US 428, 438 (2000) ("Miranda is a constitutional decision."). See Yale Kamisar, Symposium: Foreword: From Miranda to $\$ 3501$ to Dickerson to ..., 99 Mich L Rev 879, 887-88 
Miranda announced a constitutional rule and not merely an evidentiary rule that Congress could overrule. This decision ensures that Miranda will remain the centerpiece of the constitutional debate about the rules governing interrogations and confessions-and this is a debate that will continue. ${ }^{4}$ Dickerson may have resolved the issue of Miranda's constitutional status, but it did not resolve other intractable problems that flow from the Miranda opinion.

Among the most troubling of Miranda's failures is its inability to ensure the constitutional validity of confessions obtained from mentally retarded suspects. Indeed, imposing Miranda on this population exposes the opinion's most fundamental theoretical deficiencies.

Miranda's critics have spent the past three decades attacking its practical effects,' but the opinion may be most vulnerable on a theoretical level. The Miranda opinion rests upon a series of interrelated assumptions and holdings. ${ }^{6}$ Its most famous holding-that the now well-known warnings (or some equivalent mechanism) must be used to overcome the compulsion inherent in custodial interrogation-is justified by the unverified assumption that the warnings actually work. The Miranda Court assumed, without offering

\& n 33 (2001) (expressing surprise at Chief Justice Rehnquist's majority opinion in Dickerson).

3 Among the surprises was the fact that Chief Justice Rehnquist and other justices who joined in the Dickerson majority had written earlier opinions that criticized Miranda, a fact noted by the two dissenting justices. See Dickerson, 530 US at 445 (Scalia dissenting).

4 See, for example, Symposium: Miranda after Dickerson: The Future of Confession Law, 99 Mich L Rev 879 (2001).

5 The most obvious example is the ongoing debate about Miranda's impact on law enforcement. The commentary on this issue is too voluminous to be cited here. but even the direct debate between only two of the commentators on this issue is illuminating. See Paul G. Cassell, Miranda's Social Costs: An Empirical Reassessment, 90 Nw U L Rev 387, 390 (1996) (arguing that Miranda "has significantly harmed law enforcement efforts in this country"); Stephen J. Schulhofer, Miranda's Practical Effect: Substantial Benefits and Vanishingly Small Social Costs, $90 \mathrm{Nw}$ U L Rev 500, 501 (1996) (refuting Cassell's claim that Miranda undermines prosecutions); Paul G. Cassell, All Benefits, No Costs: The Grand Illusion of Miranda's Defenders, $90 \mathrm{Nw}$ U L Rev 1084 (1996); Stephen J. Schulhofer, Miranda and Clearance Rates, $91 \mathrm{Nw}$ U L Rev 278 (1996); Paul G. Cassell, Miranda's "Negligible" Effect on Law Enforcement: Some Skeptical Observations, 20 Harv J L \& Pub Pol 327 (1997); Stephen J. Schulhofer, Bashing Miranda Is Unjustified - and Harmful, 20 Harv J L \& Pub Pol 347 (1997).

6 The first assumption-that custodial interrogation is inherently coercive-is unremarkable and should be uncontroversial. Except for the small class of suspects who come forward to confess voluntarily, an essential purpose of custodial interrogation is to pressure recalcitrant suspects to confess. A second assumption, on the other hand, has provoked controversy for more than a third of a century. It posits that even interrogation tactics that would not have violated pre-Miranda "voluntariness" standards can generate pressure sufficient to violate the Fifth Amendment's prohibition of compulsory self-incrimination. For commentary placing a different emphasis upon these issues, see Stephen J. Schulhofer, Reconsidering Miranda, 54 U Chi L Rev 435, 436 (1987) (emphasizing the first assumption); Kamisar, 99 Mich L Rev at 880 n 3 (cited in note 2) (same). 
any supporting evidence, that the warnings constituted "fully effective means ... to inform accused persons of their right of silence and to ... exercise it."

This assumption is central to any claim that the warnings preserve the constitutional privilege against compulsory self-incrimination. If the warnings do not work, then the opinion's entire construct is just an elaborate sleight of hand, a device for facilitating confessions disguised as a vehicle for guarding constitutional rights.' This is possible because Miranda also made it easy to relinquish those rights.

The opinion's second critical holding selected a mechanism for allowing people to surrender their rights. The Miranda opinion imported the constitutional waiver test into Fifth Amendment doctrine, concluding that anyone can give up her Miranda "rights" by executing a waiver that is "made voluntarily, knowingly and intelligently."

In recent years, many commentators have recognized that the waiver standard has not proven to be a significant impediment to police interrogators. Statistical analyses conducted by Miranda's critics and supporters indicate that waivers are secured in an overwhelming majority of custodial interrogations ${ }^{11}$ and that these waivers are rarely invalidated by reviewing courts. Once the warnings are given, "courts find waiver in almost every case. Miranda waiver is extraordinarily

7 See notes 135-39 and accompanying text.

8 Miranda, 384 US at 444.

9 It is now widely recognized that when the police follow Miranda's procedural instructions by administering the warnings and obtaining a waiver, Miranda serves as a license, rather than an impediment, to secure usable confessions. See, for example, Dickerson, 530 US at 444, quoting Berkemer v McCarty, 468 US 420, 433 n 20 (1984) ("Cases in which a defendant can make a colorable argument that a self-incriminating statement was 'compelled' despite the fact that the law enforcement authorities adhered to the dictates of Miranda are rare."); Richard A. Leo, Questioning the Relevance of Miranda in the Twenty-First Century, 99 Mich L Rev 1000, 1012, 1017-21 (2001) (detailing methods employed by police to use loopholes and ambiguities of Miranda in securing confessions); William J. Stuntz, Miranda's Mistake, 99 Mich L Rev 975, 988 (2001) (noting that courts may tolerate more coercion because the burden is on defendants who have waived their rights to show they did not understand the warnings).

10 Miranda, 384 US at 444. This is an application of the well-known standard for waivers of constitutional rights, specifically the Sixth Amendment right to counsel, enunciated in Johnson v Zerbst, 304 US 458, 464 (1938) ("A waiver is ordinarily an intentional relinquishment or abandonment of a known right or privilege.").

11 Two leading studies suggest that approximately 75-80 percent of suspects execute Miranda waivers. See Paul G. Cassell and Bret S. Hayman, Police Interrogation in the 1990s: An Empirical Study of the Effects of Miranda, 43 UCLA L Rev 839, 850-51, 859-60 (1996) (noting that a survey of the Salt Lake County District Attorney's Office in 1994 found that 83.7 percent of suspects waived their Miranda rights); Richard A. Leo, Inside the Interrogation Room, $86 \mathrm{~J}$ Crim L \& Criminol 266, 271, 275 (noting that according to data gathered in observations of interrogations by the Laconia Police Department, 74.73 percent of suspects waived their Miranda rights). 
easy to show-basically that the suspect answered police questions after saying that he understood the warnings."12

Commentators have rarely noted, however, how these practical effects are the product of Miranda's theoretical manipulation of the waiver test. ${ }^{13}$ As applied in the interrogation setting, the waiver test has two dimensions. One requires that the waiver must be voluntarya "free and deliberate choice"-and not compelled by government pressure. The other directs that a waiver is knowing and intelligent if the person comprehends the nature of the right and the consequences of abandoning it. ${ }^{14}$

Miranda relied upon the warnings to satisfy both elements, and in the process blurred the distinction between the "knowing and intelligent" and "voluntariness" prongs of the waiver test. Once again, the opinion rested upon the unverified assumption that the warnings were effective. The Court assumed that a suspect who received the warnings not only would possess information that would ensure that a subsequent waiver was "knowing and intelligent," but also would possess the tools necessary to counteract the pressures inherent in custodial interrogation and thus ensure that a confession was "voluntary" and not compelled." The most significant and questionable theoretical innovation of the opinion was not requiring the police to administer warnings; it was using the warnings as a device for conflating the two distinct elements of the waiver test. ${ }^{16}$

12 George C. Thomas III, Separated at Birth But Siblings Nonetheless: Miranda and the Due Process Notice Cases, 99 Mich L Rev 1081, 1082 (2001).

13 Rather than focus upon the Court's use of knowledge as a surrogate for voluntariness in the waiver analysis, commentators have tended to be more concerned with how well the warnings actually "work" and their impact-or lack of it-on law enforcement. This has been true since the earliest scholarly critiques of Miranda. See, for example, Otis H. Stephens, The Supreme Court and Confessions of Guilt 170-71 (Tennessee 1973) (interpreting the well-known "Yale study," which was conducted only months after the Miranda decision, and concluding that "[m]ere warnings, often given reluctantly by the very officers intent on questioning suspected criminals, hardly ensured understanding, not to mention intelligent exercise, of constitutional rights." The critique did not address the more theoretical question of the relationship between knowledge and voluntariness.).

In more recent commentary, George Thomas has come as close as anyone at identifying the significance of the relationship between the two prongs of the waiver test in the world of Miranda. But his focus is upon the differences between the warnings as a bulwark against compulsion and the warning as a source of due-process-style notice, and not upon the merging of the two concepts. See Thomas, 99 Mich L Rev at 1081-1120 (cited in note 12).

14 Moran v Burbine, 475 US 412, 421 (1986).

15 Professor Schulhofer has argued persuasively that the post-Miranda case law has improperly interpreted compulsion to mean involuntariness. Although this development further weakens the waiver test, it is beyond the scope of the present Article. See Stephen J. Schulhofer, Miranda, Dickerson, and the Puzzling Persistence of Fifth Amendment Exceptionalism, 99 Mich L Rev 941,943-50 (2001).

16 Nor should the practical significance of the waiver test in the Miranda construct be underestimated. Once a waiver is secured, Miranda's direct impact on interrogations is limited to requiring police to stop questioning once a suspect unequivocally invokes one or more of his 
The flaws in this innovation are exposed when we apply it to the group most vulnerable to standard interrogation techniques: mentally retarded suspects. ${ }^{17}$ Miranda conceptualized suspects as rational decision makers who possessed the cognitive tools necessary to implement the warnings. ${ }^{18}$ The Court assumed that suspects would understand both the meaning and the legal significance of the warnings. Unless a suspect understands the warnings, they are but meaningless sounds. And no group is less likely to understand the warnings than is the large minority of suspects who are mentally retarded.

The empirical study presented in this paper confirms what many have suspected: mental retardation makes some people incapable of understanding either the text of the Miranda rights ${ }^{10}$ or the consequences of forsaking them. ${ }^{20}$ For these people, the words of the warnings literally have no useful meaning. The harsh reality is that for mentally retarded suspects, the Miranda warnings cannot serve the instrumental functions for which they are intended-ensuring that confessions are the product of knowing, intelligent, and voluntary waivers of the right to remain silent, and not the result of the pressures inherent in custodial interrogation. ${ }^{21}$

rights. See, for example, Michigan v Moseley, 423 US 96, 100-01 (1977) (“'Once warnings have been given, the subsequent procedure is clear. If the individual indicates in any manner, at any time prior to or during questioning, that he wishes to remain silent, the interrogation must cease."), quoting Miranda, 384 US at 473-74; Edwards v Arizona, 451 US 477, 484-85 (1981) (" $[A] n$ accused ... having expressed his desire to deal with the police only through counsel, is not subject to further interrogation by the authorities until counsel has been made available to him."). See also Kamisar, 99 Mich L Rev at 890 n 49 (cited in note 2) (citing various commentators critical of Miranda for leaving post-waiver interrogation techniques unregulated).

17 Even Miranda's most relentless critics recognize that it creates special problems for mentally retarded suspects. See, for example, Paul G. Cassell, The Paths Not Taken:The Supreme Court's Failures in Dickerson, 99 Mich L Rev 898, 939 (2001) (noting the problem of false confessions by mentally retarded suspects).

18 One of the theoretically intriguing attributes of the opinion is that its conceptualization of the suspect and his relationship to society can be placed within various philosophical traditions. From one perspective, the opinion treats the suspect as a utilitarian decisionmaker expected to balance costs and benefits. On the other hand, the opinion also appears to embrace a Kantian notion of rationality. See, for example, Charles Taylor, Hegel and Modern Society 82 (Cambridge 1979):

First of all, rationality requires that man be treated as a rätional subject, in Kant's formulation as an end, and not only as a means. And in political terms this means that the modern state must recognize the rights of the autonomous individual. . . Secondly, rationality, even in its formal Kantian definition, requires that the state be ruled by law ..., and not by arbitrary caprice; and that the law treat all alike.

But see Louis Michael Seidman, Brown and Miranda, 80 Cal L Rev 673, 738-44 (1992) (arguing that Miranda actually imposed a group rather than an individualist conception of rights).

19 The Miranda warnings "have come to be known colloquially as 'Miranda rights'...." Dickerson, 530 US at 435.

20 See Parts II and IV.

21 See Part III. 
Building upon research methods employed in earlier landmark studies of Miranda and juveniles, ${ }^{2}$ we tested a sample of mentally retarded individuals to determine if they could understand the Mirand $a$ warnings and compared the results obtained to those derived from conducting the same tests with a control group of nondisabled people. The results obtained for the mentally retarded subjects were both striking and discouraging.

22 See, for example, Thomas Grisso, Juveniles' Waiver of Rights: Legal and Psychological Competence (Plenum 1981); Thomas Grisso, Juveniles' Capacities to Waive Miranda Rights: An Empirical Analysis, 68 Cal L Rev 1134 (1980); Thomas Grisso and Carolyn Pomicter, Interrogation of Juveniles: An Empirical Study of Procedures, Safeguards and Rights Waiver, $1 \mathrm{~L}$ \& Hum Beh 321 (1977).

Other studies have evaluated the understanding of Miranda rights by nondisabled adults. See, for example, Richard Medalie, et al, Custodial Police Interrogation in Our Nation's Capital: The Attempt to Implement Miranda, 66 Mich L Rev 1347, 1375-79 (1968) (finding a correlation between defendants' level of understanding of rights and their invocation of the right to counsel and the right to silence); Lawrence Leiken, Police Interrogation in Colorado: The Implementation of Miranda, 47 Denver L J 1, 14-16 (1970) (finding that, despite warnings, many suspects do not gain adequate understanding of their rights).

Ours is the most ambitious study to date exploring empirically the understanding of the Miranda warnings by a large sample of mentally retarded people. Several papers discuss whether the courts should exempt mentally retarded defendants from the death penalty. See, for example, David L. Rumley, A License to Kill: The Categorical Exemption of the Mentally Retarded from the Death Penalty, 24 St Mary's L J 1299, 1304 (1993) (arguing that IQ should not be prima facie proof of mental retardation when deciding whether to apply the death penalty); David A. Davis, Executing the Mentally Retarded: The Status of Florida Law, 65 Fla Bar J 12, 15-16 (Feb 1991) (arguing that obstacles to such execution should be increased); Rebecca Dick-Hurwitz, Penry v. Lynaugh: The Supreme Court Deals a Fatal Blow to Mentally Retarded Capital Defendants, $51 \mathrm{U}$ Pitt L Rev 699, 707-25 (1990) (arguing that the Supreme Court confused the issues in Penry and thus erroneously reached the conclusion that it is constitutional to sentence mentally retarded defendants to death); Juliet L. Ream, Capital Punishment for Mentally Retarded Offenders: Is It Morally and Constitutionally Impermissible?, 19 Sw U L Rev 89, 129-40 (1990) (proposing guidelines that consider mental age and capacity to comprehend consequences). However, these papers contain no empirical evidence on whether mentally retarded people understand either the criminal justice system or their rights. Two other papers generally discuss the validity of confessions by the mentally retarded, but again offer no empirical evidence concerning understanding of the issues by these individuals. See Paul Hourihan, Earl Washington's Confession: Mental Retardation and the Law of Confessions, 81 Va L Rev 1471, 1491-94 (1995) (noting that mentally retarded people are (1) more susceptible to coercion, (2) more likely to confess falsely, and (3) less likely to understand their Miranda rights and the consequences of waiving them); James W. Ellis and Ruth A. Luckasson, Mentally Retarded Criminal Defendants, 53 Geo Wash L Rev 414, 445-52 (1985) (noting that mental retardation increases the likelihood of being "abnormally susceptible" to coercion and pressure and that therefore retarded individuals are more likely to give confessions that are not truly voluntary). A brief research Note employs parts of the Grisso methodology to craft an interesting, but admittedly preliminary, understanding of the Miranda warning by mentally retarded people. Solomon M. Fulero and Caroline Everington, Assessing Competency to Waive Miranda Rights in Defendants with Mental Retardation, 19 L \& Hum Beh 533, 541 (1995). Although the Note finds that retarded subjects lacked understanding, the study contained only a small sample of subjects with only mild or moderate disability, African-American males severely overrepresented, no nonretarded control subjects, and no IQ information for the individual subjects. As a result of its limited scope, the Note could not evaluate the courts' current totality-of-the-circumstances test for evaluating waiver by disabled suspects or examine the effectiveness of simplified warnings. 
The results indicate that mentally retarded people simply do not understand the Miranda warnings. Virtually all of the disabled subjects failed to understand the context in which interrogation occurs, the legal consequences embedded in the rules or the significance of confessing, the meaning of the sentences that comprise the warnings, or even the individual operative words used to construct the warnings. In contrast, comparably large percentages of the nondisabled control group did understand the individual words, the complete warnings, and their legal significance. ${ }^{23}$

The possibility that some mentally retarded people cannot comprehend the Miranda warnings has been debated within the judicial system for some time, ${ }^{24}$ but the results of this study do more than confirm these suspicions. The results support two additional conclusions about the constitutional validity of confessions by mentally retarded suspects that will be surprising to many and should be troubling to anyone examining the criminal justice system.

First, the data suggest that the number of people to whom the Miranda warnings are meaningless is much larger than previously acknowledged within the criminal justice system. The warnings are incomprehensible not merely to those suffering the most severe retardation, as many judicial opinions assume. They also are incomprehensible to people whose mental retardation is classified as mild, as well as some people whose "intelligence quotient" (IQ) scores exceed 70 , the number typically used to demarcate mental retardation. ${ }^{25}$

Second, the results of this study raise disquieting questions about the capacity of contemporary constitutional doctrine to accommodate the special problems accompanying police interrogations of mentally retarded suspects. When confronted with challenges to the validity of a mentally retarded suspect's waiver of the Miranda "rights,", courts typically revert to a "totality of the circumstances" analysis to determine whether the suspect was capable of understanding the Miranda warnings. ${ }^{27}$ Courts utilizing a "totality of the circumstances" analysis typically examine factors including the suspect's IQ, age, educational level, experience with the criminal justice system, and history of being "Mirandized" as indicators of a mentally retarded person's competence to understand the warnings and to execute a

23 See Part IV.B.

24 See notes $160-75$ and accompanying text.

25 See Part IV.B.1.

26 See Dickerson, 530 US at 435 (noting that references to the Miranda "rights" are now common).

27 See Charles C. Marvel, Mental Subnormality of Accused as Affecting Voluntariness or Admissibility of Confession, 8 ALR 4th 16 (1981) (collecting cases employing these methods). 
valid waiver. ${ }^{28}$ We attempted to determine whether these factors correlate with an understanding of the Miranda warnings by mentally retarded people. The data derived from the participants in this study suggest that the "totalities" analysis employed by the courts is incapable of identifying suspects competent to understand the Miranda warnings.

Instead, the results of this empirical analysis indicate that the factor that matters is the presence of retardation, even mild retardation. Multiple regression analysis demonstrates that variations in age, education, and experience with the criminal justice system or the Miranda warnings do not compensate for a mentally retarded person's inability to comprehend the warnings. If mental retardation is present, then the disabled person will not understand the warnings, regardless of the presence of the other factors.

These data indicate that waivers of the Miranda "rights" by this population are not "knowing" or "intelligent" in any meaningful sense of those words. Neither the primary device used during custodial interrogations - the Miranda warnings - nor the traditional "totalities" analysis is an adequate device for enforcing the constitutional rights of this population. The results of this study suggest that the words "knowing and intelligent" have no useful meaning as our courts apply them to waivers of the Miranda "rights" by mentally retarded suspects. In fact, the relevant constitutional terminology is meaningless for this population from at least three different perspectives.

First, the words comprising the Miranda warnings themselves are "meaningless" in the sense that the object of the warnings-the mentally retarded suspect-cannot subjectively understand them; the words are without meaning to him. ${ }^{29}$ Second, the words used to define the standards for a constitutionally valid waiver-"knowing," "intelligent," and "voluntary" - are "meaningless" in the sense that the courts frequently apply them to mentally retarded suspects in ways that contradict the very meaning of these words. ${ }^{30}$ The results of this

28 See notes 156-57 and accompanying text. See also People v Tackett, 246 Ill App 3d 622, 616 NE2d 691, 693 (1993) (evaluating the totality of the circumstances by looking at the defendant's mental ability, familiarity with English, age, education, and experience); People v Racanelli, 132 Ill App 3d 124, 476 NE2d 1179, 1184-85 (1985) (evaluating the totality of circumstances by looking at the defendant's age, intelligence, experience with the law, and emotional stability); Fields $v$ State, 402 S2d 46, 48 (Fla App 1981) (allowing suppression of defendant's statements because of "[t]he circumstances of appellant's interrogation, coupled with the evidence of his diminished mental capacity").

29 The definitions of "meaning" include: "That which is intended to be or actually is expressed or indicated; that which a speaker or writer intends to express; the intended sense of (a person's) words; knowledge, understanding." 9 Oxford English Dictionary 522 (2d ed 1989).

30 Definitions of "meaningless" include "having no assigned function in a language system." Merriam-Webster's Collegiate Dictionary 720 (10th ed 1997). Another dictionary defines meaningless as "[w]ithout meaning or signification; devoid of expression; without purpose. Also, 
study suggest that when a judge examines the typical "totalities" factors and relies upon them in reaching the conclusion that a mentally retarded suspect's waiver of his Fifth Amendment privilege was "voluntary," knowing, and intelligent," the conclusion is accurate only if we are willing to manipulate and distort the meaning of language.

This brings us to yet a third way that words may have no useful meaning when we are discussing confessions by mentally retarded suspects. We are referring now to the words of the confessions themselves. The constitutional test of waivers permits the exclusion of even truthful and accurate confessions that were the product of government coercion or that were not "knowing and intelligent." But confessions by mentally retarded suspects may suffer from an even more troubling flaw-they may be false.

It now seems beyond legitimate dispute that mentally retarded suspects are likely to confess falsely (that is, confess to crimes they did not commit) far more frequently than do suspects of average and above-average intelligence. Similarly, interrogation tactics generally believed to be acceptable with most suspects ${ }^{34}$ are more likely to produce false confessions from mentally retarded suspects. Given the proclivity of this population to confess falsely, it seems inevitable that in some number of cases false confessions have led to the conviction

"not meaningful." 9 Oxford English Dictionary at 523.

31 "Voluntary" has a specialized meaning in Fifth Amendment doctrine. It does not mean "voluntary" in the sense of "having the power of free choice," Merriam-Webster's Collegiate Dictionary 1324 (10th ed 1997), or "[a]rising from or acting on one's own free will," The American Heritage Dictionary of the English Language 2002 (3d ed 1992). Instead, it means only that the confession is not the product of government coercion. See Colorado $v$ Connelly, 479 US 157,167 (1986) ("We hold that coercive police activity is a necessary predicate to the finding that a confession is not 'voluntary."). See notes $289-90$ and accompanying text.

32 Definitions of "knowing" include: "has knowledge of truths or facts; understanding, intelligent, instructed, enlightened, well-informed." 8 Oxford English Dictionary 516 (2d ed 1989). Another set of definitions includes "having or reflecting knowledge, information or intelligence." Merriam-Webster's Collegiate Dictionary 647 (10th ed 1997).

33 As we shall see, the subjects of this study fail to satisfy the core definitions of "intelligent" relevant to the question of waiver. They fail the conventional notions of "[h]aving the faculty of understanding; possessing intelligence or intellect; [h]aving a high degree or full measure of understanding; quick to understand; knowing, sensible, sagacious; [s] howing a high (or fair) degree of understanding," 7 Oxford English Dictionary 1070 (2d ed 1989); "having or indicating a high or satisfactory degree of intelligence and mental capacity," Merriam-Webster's Collegiate Dictionary 608. The data in this study indicate that they also fail to "reveal[ ] or reflect [ ] good judgment or sound thought." Id. See also American Heritage Dictionary of the English Language 938 (3d ed 1992) ("Showing sound judgment and rationality: an intelligent decision.").

34 See, for example, Welsh S. White, False Confessions and the Constitution: Safeguards against Untrustworthy Confessions, 32 Harv CR-CL L Rev 105, 118-21 (1997) (examining the effect of standard interrogation techniques upon both nondisabled and mentally retarded people).

35 See Hourihan, 81 Va L Rev 1471 (cited in note 22). 
and imprisonment of innocent mentally retarded suspects. Indeed, cases in which mentally retarded suspects have been convicted, and in some cases sentenced to death for crimes they did not commit (with their false confessions serving as critical evidence against them), have been reported with increasing frequency in recent years. ${ }^{36}$ This increased reporting results, at least in part, from concerns about the execution of mentally retarded people. ${ }^{37}$ Although cases in which mentally retarded people are sentenced to death may receive the most public attention because they force us to confront the most powerful moral issues, statistically these cases represent only the "tip of the iceberg" of the theoretical and practical problems raised when the criminal justice system must cope with mentally retarded suspects and defendants. ${ }^{38}$

No one can claim to know with certainty the precise number of mentally retarded people who are arrested, interrogated, convicted, and incarcerated each year, ${ }^{39}$ but the best available data suggest that at least forty-five thousand, and perhaps more than two hundred thousand, mentally retarded people currently are imprisoned in the United States. ${ }^{40}$ Undoubtedly, these people have been arrested. Many,

36 See, for example, Richard Leo and Richard Ofshe, The Consequences of False Confessions: Deprivations of Liberty and Miscarriages of Justice in the Age of Psychological Interrogation, 88 J Crim L \& Criminol 429, 485-86 nn 464-74, 487 nn 480-81, 490-91 nn 512-29 (1998) (discussing specific cases in which mentally retarded suspects confessed falsely and were convicted).

37 See, for example, Penry v Johnson, 121 S Ct 1910, 1924 (2001) (reversing the death penalty imposed upon a mentally retarded defendant for the second time). The Supreme Court granted certiorari in McCarver v North Carolina, 121 S Ct 1401 (2001), to address the question of the constitutionality of executing mentally retarded suspects. North Carolina subsequently enacted legislation prohibiting such executions, leading the Court to withdraw its grant of certiorari. See McCarver v North Carolina, 2001 US LEXIS 5345. However, on the same day, the Court granted certiorari in another case, Atkins v Virginia, 2001 US LEXIS 5356, amended at 2001 US LEXIS 5463, to decide whether the execution of mentally retarded people violates the Eighth Amendment. Raymond Bonner, Argument Escalates on Executing Retarded, NY Times A12 (July 23, 2001).

38 See, for example, Grisso, Juvenile's Waiver of Rights at 214-16, table A-3 (cited in note 22) (noting that almost 14 percent of defendants officially qualify as mentally retarded, with IQs below 70 , compared to only 1 percent of the general population; more than 30 percent of criminal defendants have IQs below 80, compared to 19 percent of the general population).

39 See, for example, Mentally Retarded Assistance and Bill of Rights Act, 42 USC $\S 6000$ (a)(1) (1994) (noting congressional finding that in 1993 there were "more than 3,000,000 individuals with developmental disabilities in the United States"), repealed by Pub L No 106402, title IV \& 401a, 114 Stat 1737 (2000).

40 Mentally retarded suspects comprise somewhere between 2 and 10 percent of the population of prisoners. See, for example, Arthur L. Bowker, Handle with Care, Dealing with Offenders Who Are Mentally Retarded, 63 FBI L Enforcement Bull 12, 12 (1994) (giving the figures as from 5 to 10 percent), citing C.O. McDaniel, Is Normalization the Answer for MROs?, Corrections Today 184 (1987), and M. Sanntamour, The Offender with Mental Retardation, 66 Prison J 3 (1986); John H. Noble, Jr. and Ronald W. Conley, Toward an Epidemiology of Relevant Attributes, in Ronald W. Conley, et al, eds, The Criminal Justice System and Mental Retardation 17,37 (Paul Brooks 1992) (giving reasons for the variance in the estimates). Over two million 
probably most, have been "Mirandized" and interrogated while in custody. Some have waived their rights and made statements to investigators. The frequency of these confessions is confirmed by the seemingly endless stream of reported decisions involving confessions by defendants of subnormal intelligence, ${ }^{41}$ including a number of the Supreme Court's confession cases.

In some of these cases, mentally retarded defendants were sentenced to die. By some estimates, as many as 20 percent of the people on death row are mentally retarded, ${ }^{43}$ and death penalty opponents contend that at least three dozen mentally retarded people have been executed in the quarter century since the death penalty was reinstated. ${ }^{4}$ The most disturbing cases are those in which the prosecution, conviction, and death sentence rest largely upon a disabled suspect's confession, and that confession is later proven to be false. ${ }^{45}$ The Supreme Court will soon decide whether the Constitution permits execution of mentally retarded defendants. ${ }^{45}$ This paper addresses a related question: whether the Constitution permits a retarded person to be convicted based upon his confession.

It can be difficult to understand why an innocent person would confess, particularly to a crime so heinous that it warrants the death penalty. But if the person subjected to custodial interrogation is mentally retarded, the possibility that he will confess to a crime he did not commit should not be surprising.

To explain why mentally retarded suspects are unusually vulnerable to the pressures inherent in custodial interrogation, Part II of this Article presents a discussion of the nature of mental retardation and then examines how this disability affects the capacity of people to cope with the pressures of custodial interrogation. In Part

people are incarcerated in prisons and jails. U.S. Department of Justice, Prisoners in 1999, Bulletin 1 (Aug 2000), available online at <http://www.ojp.usdoj.gov/bjs/pub/pdf/p99.pdf (visited Mar 12,2002).

41 See, for example, Marvel, 8 ALR 4th at 24-60 (cited in note 27) (discussing voluminous cases in state and federal courts).

42 Several of these cases were decided in the years leading up to Miranda, or soon after it was decided. See, for example, Sims v Georgia, 389 US 404 (1967) (noting the limited mental capacity of the accused, who had a third grade education level); Reck $v$ Pate, 367 US 433 (1961) (involving a mentally retarded youth who was interrogated incommunicado for a week during which he grew ill and vomited blood); Culombe v Connecticut, 367 US 568 (1961) (holding that the accused, who had an IQ of 64, was suggestible and subject to intimidation); Payne v Arkansas, 356 US 560 (1958) (involving a "mentally dull" youth, whom the Supreme Court found "confessed" due to the use of coercion).

43 See notes $36-40$ and accompanying text.

44 See Daniel W. Keyes and William J. Edwards, Mental Retardation and the Death Penalty: Current Status of Exemption Legislation, 1997 Mental \& Physical Disability L Rep 687 (1997).

$45 \mathrm{See}$, for example, Hourihan, $81 \mathrm{Va}$ L Rev at 1471 (cited in note 22) (giving an example of a death sentence based on false conviction).

46 See note 37. 
III, we examine the constitutional standards governing confessions and the methods commonly used by courts to judge the validity of confessions by mentally retarded suspects. The discussion focuses upon Miranda's frequently misunderstood conceptual framework and explains why the theoretical innovations upon which the opinion rests ensure that it is likely to be inadequate, perhaps irrelevant, when the person being interrogated is mentally retarded.

At a minimum, if the Miranda construct of warnings and waiver is to amount to something more than a "form of words,", the people warned must have the cognitive capacity to comprehend the rights described by their interrogators. The empirical study presented in this Article addresses this issue directly by studying the capacity of a subject population of mentally retarded individuals to understand the Mirand $a$ warnings and then comparing their performance with the results obtained from a control group of nondisabled people. Part IV explains the methodology employed in this study, then presents the findings.

Given the apparent failure of the current system to cope effectively with the problems generated by confessions by mentally retarded suspects, Part V explores other possible methods for dealing with the theoretical problems this population creates for our present constitutional doctrine, as well as the practical difficulties they pose for the criminal justice system. Unfortunately, the problem of ensuring that confessions by mentally retarded suspects are "voluntary, knowing, and intelligent" is not easily solved. As we discuss in the final Part of this Article, the difficulty is so great that some may be tempted to retain the current approach. After all, legal rules that are crafted with words inevitably fail in some situations. The indeterminacy of language ${ }^{48}$ and the finite capacity of the human mind to comprehend information dictate that if a legal system relying upon rules framed with words is to function, it must accept the inevitability of errors in some cases ${ }^{49}$ and suboptimal outcomes in others. ${ }^{\text {so }}$

47 Miranda, 384 US at 444 (1966), quoting Silverthorne Lumber Co v United States, 251 US 385, 392 (1920):

This was the spirit in which we delineated, in meaningful language, the manner in which the constitutional rights of the individual could be enforced against overzealous police practices. It was necessary in Escobedo, as here, to ensure that what was proclaimed in the Constitution had not become but a "form of words."

48 H.L.A. Hart, The Concept of Law 125-29 (Oxford 2d ed 1994) (arguing that linguistic indeterminacy affects the specific application of general legal rules); H.L.A. Hart, Positivism and the Separation of Law and Morals, 71 Harv L Rev 593, 607 (1958) (noting that the general words we use have a "penumbra of debatable cases in which words are neither obviously applicable nor obviously ruled out").

49 The "harmless error" rule is a classic example. Even errors derogating fundamental rights are acceptable if they are "harmless" in the context in which they occur. See, for example, 
These rough accommodations may be inevitable, but they must also have their limits. Just as it is unjust to punish those who transgress a rule they cannot understand because it is incomprehensible, it seems unjust to require a person to comply with a legal standard when mental disability prevents her from understanding the rule. ${ }^{52}$ Ultimately the Article concludes that, of the possible alternatives that might work to protect the rights of mentally retarded suspects, only some form of per se rule limiting the use of their confessions is a viable means of implementing constitutional norms governing waivers of rights. To understand why we reach this conclusion, it is necessary to understand the nature of mental retardation and the impact this disability has on a person's capacity to function in the justice system.

\section{MENTALLY RETARDED SUSPECTS, FREE WILL, AND FALSE CONFESSIONS}

\section{A. Mental Retardation}

For centuries, Anglo-American law has recognized that some legal standards of general application cannot be applied to mentally retarded people. From the Middle Ages until well into the twentieth century, the English and then the American legal systems labeled these people as "idiots," "imbeciles," and "feebleminded,", developed

Arizona v Fulminante, 499 US 279, 295 (1991) (applying the harmless error rule to the admission of involuntary confessions); Chapman v California, 386 US 18, 24 (1967) (stating that before a federal constitutional error can be held harmless, the reviewing court must be able to declare a belief that it was harmless beyond a reasonable doubt).

50 Frederick Schauer, Playing by the Rules: A Philosophical Examination of Rule-Based Decision Making in Law and in Life 100-02 (Oxford 1991) (arguing that, since rules are afflicted by the indeterminacy of language, in some cases strict rule application produces suboptimal results).

51 Enforcing a rule that is so vague that it cedes excessive discretion to law enforcers, or that it cannot be understood by a reasonable, average person, violates fundamental notions of due process. See, for example, City of Chicago v Morales, 527 US 41, 57-60 (1999) (holding that Chicago's gang loitering ordinance was overly vague and gave police officers too much discretion); Kolender $v$ Lawson, 461 US 352, 361 (1983) (holding that a loitering statute was unconstitutional because it contained a vague standard that could lead to arbitrary enforcement); City of Jacksonville v Papachristou, 405 US 156, 162 (1972) (holding a statute void for vagueness because it did not give fair notice of forbidden activity and encouraged arbitrary arrest by police).

52 See note 54 and accompanying text (discussing treatment of mentally retarded people by medieval English law).

53 See, for example, Issac Ray, A Treatise on the Medical Jurisprudence of Insanity 227 (Harvard 1st ed 1883) (1962 reprint) ("Idiocy, imbecility, and senile dementia admit neither of cure nor amelioration."); Comment, Lunacy and Idiocy-The Old Law and Its Incubus, $18 \mathrm{U}$ Chi L Rev 361, 361-62 (1951) (distinguishing between lunatics and idiots, and describing idiots as having been born "mentally deficient or disturbed"); Frank C. Richmond, The Criminal Feebleminded, $21 \mathrm{~J}$ Crim L \& Criminol 537, 540-42 (1931) (providing classifications of the "feeble-minded"); Henry Herbert Goddard, The Criminal Imbecile: An Analysis of Three Remarkable Murder Cases (MacMillan 1915) (comparing the mental attributes of three 
"tests" to distinguish "idiots" from "normal" people, and held "idiots" to different legal standards from those imposed on others.

Today the mental health and legal professions label these people as "mentally retarded" or "developmentally disabled." In this paper, we generally use the term "mentally retarded" because it is "the accepted term in modern usage" in the legal system. Although the contemporary labels may be more benign than the earlier use of "idiots" and "imbeciles," the reality of the incapacities that burden these people remains the same. Their cognitive and social limitations make mentally retarded people more vulnerable to a wide range of dangers, including confessing to crimes they have not committed. ${ }^{38}$ The results of this study confirm what has long been suspected: the rules announced in Miranda simply are inadequate to counteract these profound cognitive and social limitations.

\footnotetext{
"imbecile" murder defendants); Henry Herbert Goddard, Feeble-Mindedness: Its Causes and Consequences (MacMillan 1914) (providing case studies and heredity charts of "morons" and the "feeble-minded"); Walter Elmore Fernald, The Imbecile with Criminal Instincts, $14 \mathrm{~J}$ PsychoAsthenics 16 (1909) (comparing the definitions of nineteen "imbecile" defendants), reprinted in Marvin Rosen, et al, eds, 2 The History of Mental Retardation: Collected Papers 165-84 (University Park 1976); Anthony Highmore, A Treatise on the Law of Idiocy and Lunacy 195 (J. Butterworth 1807) (distinguishing between idiocy and lunacy), reprinted in Classics of English Legal Theory (Garland 1979).

54 See, for example, S. Sheldon Glueck, Mental Disorder and the Criminal Law 128 (Little, Brown 1925), quoting A. Fitzherbert, Natura Brevium (1534) (describing the "twenty pence" test that could be traced back to the Middle Ages):
}

[An idiot is] a person who cannot account or number twenty pence, nor can tell who was his father or mother, nor how old he is, etc., so as it may appear he hath no understanding of reason what shall be for his profit, or what for his loss. But if he have such understanding that he know and understand his letters, and do read by teaching of another man, then it seems he is not a sot or natural fool.

55 Id.

56 See, for example, American Psychiatric Association, Diagnostic and Statistical Manual of Mental Disorders 41 (4th ed text rev 2000) ("DSM-IV-TR").

57 Ellis and Luckasson, 53 Geo Wash L Rev at 421 n 38 (cited in note 22). See, for example, Penry v Johnson, 532 US 782 (2001); Olmstead v L.C., 527 US 581 (1999); Heller v Doe, 509 US 312 (1993). The other term used today, "developmentally disabled," has the additional drawback of being less precise. It encompasses various conditions, only one of which is mental retardation. See Ellis and Luckasson, 53 Geo Wash L Rev at 421 n 38, citing Mentally Retarded Assistance and Bill of Rights Act, 42 USC $\$ \S 6000-81$, repealed by Pub L No 106-402, title IV $\S 401 a$, 114 Stat 1737.

58 See notes 22, 36 and accompanying text. See also Herbert J. Grossman, ed, Classification in Mental Retardation 1, 11 (American Association of Mental Deficiency 3d ed 1983) ("AAMD") ("Mental retardation refers to significantly subaverage general intellectual functioning resulting in or associated with concurrent impairments in adaptive behavior and manifested during the development period."). This definition was accepted by the Supreme Court in City of Cleburne v Cleburne Living Center, Inc, 473 US 432, 443 (1985). For additional definitions, see also AAMD at 11 (definition encompasses not only the IQ test measure of cognitive functioning, but also limits of adaptive behavior that are "significant limitations in an individual's effectiveness in meeting the standards of maturation, learning, personal independence, and/or social responsibility that are expected for his or her age level and cultural group, as determined by clinical assessment and, usually, standardized scales"). 
It now seems beyond reasonable dispute that "[t]he increased vulnerability of a mentally disabled suspect, and his or her naivete, ignorance, confusion, suggestibility, delusional beliefs, extraordinary susceptibility to pressure, and similar considerations may make it possible for law enforcement officers to induce an involuntary statement by using techniques that would be acceptable in cases involving mentally typical suspects." ${ }^{, 59}$ This results from the nature of mental retardation.

Mental retardation is defined as significantly subaverage general intellectual functioning that is accompanied by significant limitations in adaptive functioning and an onset during the early developmental period. $^{\circ}$ General intellectual functioning is measured by IQ, with "significantly subaverage" (the standard for mental retardation) set at an IQ of 70 or below."

"Limitations in adaptive functioning" refers to a disabled person's reduced ability to interact and communicate with others and to live independently and responsibly. ${ }^{62}$ Onset during early development means that the individual exhibits both subaverage intellectual functioning and deficits in adaptive behavior before the age of eighteen..$^{63}$ Mental retardation is different from mental illness, although a person may exhibit both conditions. ${ }^{64}$

People with mental retardation are not a homogenous group. They vary enormously in aptitude, personality, achievement, and temperament. However, they generally are classified according to the severity or degree of their disabilities. Because of the difficulty of testing adaptive functioning, and despite concerns about the accuracy of IQ testing, ${ }^{65}$ mental retardation most often is identified by means of intelligence tests. ${ }^{60}$ Based upon their IQs, people who are mentally

59 ABA Criminal Justice Mental Health Standards, Standard 7-5.8 (Statements by mentally ill or mentally retarded persons) commentary (1989). See also Bowker, 63 FBI L Enforcement at 12 (cited in note 40).

60 See DSM-IV-TR at 41 (cited in note 56) ("The essential feature of Mental Retardation is significantly subaverage intellectual functioning.").

61 Id.

62 Id.

63 Id.

64 "Mentally ill people encounter disturbances in their thought process and emotions." Ellis and Luckasson, 53 Geo Wash L Rev at 424 (cited in note 22). In contrast, the mentally retarded have limited abilities to learn. Id. "Many forms of mental illness are temporary, cyclical, or episodic." Id. In contrast, mental retardation involves a mental impairment that is permanent. Id. Although the consequences of mental retardation can be ameliorated through education and habilitation, it has no cure. Id. As a result, an individual with mental retardation will be no better able to resist coercive interrogation or to comprehend a waiver form after a few days' rest than he or she was before. See id.

65 See generally Rumley, 24 St Mary's L J at 1329-41 (cited in note 22) (discussing the unreliability of IQ tests).

66 Current intelligence tests are designed so that two-thirds of the population will obtain 
retarded are grouped into four categories: mild, moderate, severe, and profound.

The "highest" classification of mental retardation is "mild," and it applies to individuals with IQ scores ranging between 50 to 55 and approximately $70 .^{67}$ The casual observer often does not notice these people as being mentally retarded. With appropriate support, individuals with mild disability can usually live successfully in the community, either independently or in supervised settings. ${ }^{63}$

"Moderate" retardation, the second classification, includes people with IQs ranging between 35 to 40 and 50 to 55 . Virtually all mildly and moderately retarded people have the ability to conform to the customs, habits, and standards of behavior in society and to do so independently of direction and guidance.

The third classification is "severe," which applies to people who have IQ scores ranging between 20 to 25 and 35 to 40 . These people can conform to daily routines and repetitive activities. Although they have the capability to learn simple work skills, they are usually incapable of self-maintenance..$^{70}$

The "lowest" level is "profound" mental retardation, which describes people who have an IQ below 20 or 25 . These individuals will usually benefit from physical activity, but are incapable of selfmaintenance."

The distribution of people among these four categories is skewed. "Approximately eighty-nine percent of the people classified as

an IQ of 85 to 115 , the highest 1 percent will obtain a score of 135 or above, and the lowest 1 percent will obtain an IQ of 65 or below. See DSM-IV-TR at 39 (cited in note 56).

67 See, for example, AAMD at 27 (cited in note 58).

68 People with mild disability "typically develop social and communication skills during the preschool years, [ ] have minimal impairment in sensor motor areas, and often are not distinguishable from children without Mental Retardation until a later age." DSM-IV-TR at 43 (cited in note 56). "By their late teens, they can acquire academic skills up to approximately the sixth-grade level." Id. As adults, "they usually achieve social and vocational skills adequate for minimum self-support, but may need supervision, guidance, and assistance." Id.

69 Most people with moderate disability acquire communication skills during early childhood years. "They profit from vocational training and, with moderate supervision, can attend to their personal care." Id. "They can also benefit from training in social and occupational skills but are unlikely to progress beyond the second-grade level in academic subjects." Id. "During adolescence, their difficulties in recognizing social conventions may interfere with peer relationships." Id. As adults, most can "perform unskilled or semiskilled work under supervision." Id.

70 During the early childhood years, they acquire little communicative speech, although later "they may learn to talk and can be trained in elementary self-care skills." Id. They profit little from academic instruction, "but can master skills such as learning sight reading of some 'survival' words." Id. "In their adult years, they may be able to perform simple tasks in closely supervised settings." Id.

71 "Most individuals with this diagnosis have an identified neurological condition that accounts for their Mental Retardation." Id at 44. 
mentally retarded fall within the 'mildly retarded' category," and approximately 95 percent of mentally retarded people have the potential to be economically productive. ${ }^{73}$ Only about 1 percent of all mentally retarded persons in the United States qualify as severely or profoundly disabled. ${ }^{74}$

Even this brief overview of the nature of retardation identifies one fundamental difficulty faced by law enforcers, judges, prosecutors, and defense lawyers dealing with mentally retarded suspects. Because the great majority of this population suffers from a mild or moderate disability, it can be hard to identify these people as mentally retarded, and easy to overestimate their intellectual capacity to understand the meaning and significance of relatively complex concepts, such as the Miranda warnings. ${ }^{75}$ These difficulties are magnified by a number of psychological characteristics that members of this population frequently exhibit.

\section{B. Common Psychological Characteristics Associated with Mental Retardation}

Despite the differences among mentally retarded people, they do tend to share common and well-known psychological characteristics that make them especially susceptible to the pressures generated by contemporary police interrogation methods. The following list of seven common characteristics illustrates why mentally retarded people are poorly equipped to cope with the pressures of interrogation and are predisposed to confess falsely.

First, mentally retarded people are unusually susceptible to the perceived wishes of authority figures. ${ }^{76}$ Even when no direct pressure is exerted on them, they may be inclined to make false statements out of a desire to please perceived authority figures." A common

72 Ellis and Luckasson, 53 Geo Wash L Rev at 423 n 49 (cited in note 22), citing American Psychiatric Association, Diagnostic and Statistical Manual of Mental Disorders 40 (3d ed 1980) ("DSM-III"). See also DSM-IV-TR at 41 (cited in note 56).

73 Ellis and Luckasson, 53 Geo Wash L Rev at $423 \mathrm{n} 49$ (cited in note 22), citing DSM-III at 40. See also DSM-IV-TR at 43 (cited in note 56).

74 See DSM-IV-TR at 44 (cited in note 56).

75 See, for example, Bowker, FBI L Enforcement Bull at 12 (cited in note 40). See also note 68 and accompanying text.

76 See, for example, Harter, Mental Age, IQ and Motivational Factors in the Discrimination Learning Set Performance of Normal and Retarded Children, 5 J Experimental Child Psych 123, 137-38 (1967) (finding that mentally retarded individuals seek approval from authority figures even when it requires giving an answer they know to be incorrect); Carol K. Sigelman, et al, When in Doubt, Say Yes: Acquiescence in Interviews with Mentally Retarded Persons, 19 Mental Retardation 53 (1980) (discussing studies that show mentally disabled individuals are more likely than nondisabled individuals to answer "yes" and comply with unreasonable instructions).

77 See Ellis and Luckasson, 53 Geo Wash L Rev at 430 (cited in note 22) ("[S]ome people with mental retardation will eagerly assume blame in an attempt to please or curry favor with an 
phenomenon is the mental process of "cheating to lose," that is, accepting blame so that others will not be angry. ${ }^{78}$ If an authority figure such as a police officer makes it clear to the individual that he wants a confession, even an innocent disabled person may confess so a law enforcement officer will not become angry with him."

Second, a generalized desire to please may predispose many mentally retarded people to give biased responses. ${ }^{80}$ They tend to give affirmative answers to questions inquiring about behaviors they believe are desirable. Conversely, mentally retarded people are likely to answer negatively questions involving conduct they believe is disfavored. As a result, a disabled individual may give an incorrect response to a question if he believes that this is the answer that an authority figure like a police officer seeks.

Third, mentally retarded people often are unable to discern when they are in an adversarial situation, especially with police officers. ${ }^{81}$ Often they have been taught that a police officer is someone to trust, someone who will provide help. It may be impossible for the retarded person to understand that a police officer assisting a person in need plays a different role from one who is interrogating suspects. The susceptibility of this population to threats and coercion is significant, but their inability to cope with a complex social event such as custodial interrogation also is influenced by their vulnerability to an outward display of friendliness that is designed to induce confidence and cooperation. Mentally retarded people may have difficulty distinguishing between the fact and the appearance of friendliness, making them particularly vulnerable to subtle and nonphysical intimidation and coercion.

Fourth, people with mental retardation tend to have incomplete or immature concepts of blameworthiness and culpability. A disabled person may be unable to distinguish between an incident that results from culpable behavior and an incident that results from a situation

accuser. This phenomenon of 'cheating to lose' may give rise to unfounded confessions.").

78 Id.

79 See Fred E. Inbau, et al, Criminal Interrogation and Confessions (Williams \& Wilkins 3d ed 1986).

80 See Ellis and Luckasson, 53 Geo Wash $\mathrm{L}$ Rev at 428 (cited in note 22) ("For example, many people with mental retardation are predisposed to "biased responding."').

81 See, for example, Ellis and Luckasson, 53 Geo Wash L Rev at 451 (cited in note 22), citing President's Panel on Mental Retardation, Report of the Task Force on Law 33 (1963) (noting that the retarded tend toward submissiveness in the face of police pressures); H.R. Turnbull, ed, Consent Handbook 11 (American Association on Mental Deficiency 1977) (noting the possibility that a mentally retarded person might be more vulnerable to police pressures for a variety of reasons).

82 Hourihan, 81 Va L Rev at 1493 (cited in note 22).

83 See id. 
that is beyond the person's control. ${ }^{84}$ A mentally retarded individual may confess to a crime that he did not commit because he believes that blame should be assigned to someone, and he is unable to understand the concept of causation and his role in the incident.

Fifth, mentally retarded people often appear to be impulsive or to have poor impulse control. ${ }^{85}$ This characteristic appears to be related to problems involving attention span, focus, and selectivity in the attention process. Deficits in attention or impulse control may cause mentally retarded people to answer a question without giving any consideration to the consequences.

Sixth, some retarded people have inaccurate views of their own capacities. It is not uncommon for disabled people to overrate their skills. This tendency may influence their estimates of their academic achievement, physical skills, and intellectual level. It occurs either because of a genuine misconception of their own abilities or because of defensiveness about the disability. ${ }^{86}$ A disabled person may feel compelled to answer a question, even if the question exceeds his ability to answer. ${ }^{87}$

Finally, all of these problems can be compounded by a tendency not to identify themselves as disabled. This can occur in any life setting. Mentally retarded people may attempt to hide their disabilities, and many become skillful at masking their limitations. ${ }^{83}$ The impact of this masking behavior is compounded by the reality that those who administer the criminal justice system often are poorly equipped to identify mental retardation. ${ }^{89}$ The limited ability of most

84 Id ("Some mentally retarded persons have incomplete concepts of blameworthiness and culpability.").

85 See AAMD at $98-99$ (cited in note 58).

86 See, for example, Thomas A. Ringness, Self-Concept of Children of Low, Average, and High Intelligence, 65 Am J Mental Deficiency 453, 456-60 (1961) (providing data indicating a high self-concept for mentally retarded students and identifying possible explanations). For an example of a judicial response to this issue, see Reddix $v$ Thigpen, 805 F2d 506, 515-16 (5th Cir 1986) (upholding the admission of defendant's confession in a state criminal prosecution despite his claim that he was unable to waive his constitutional rights voluntarily, knowingly and intelligently; concluding that a psychiatrist's report stating that defendant's mental retardation made him particularly vulnerable to outside influences and prevented sufficient comprehension of his rights merely conflicted with defendant's testimony that he understood his rights and was not coerced).

87 Numerous participants involved in our study answered yes to questions that they neither understood nor were able to answer. That individuals with a mental retardation often answer questions that are beyond their capability raises concerns about the accuracy of their statements. See Hourihan, 81 Va L Rev at 1493 (cited in note 22).

88 See ABA Criminal Justice Mental Health Standard 7-5.9 (Waiver of rights by mentally ill or mentally retarded persons) commentary ("[M]any mildly and moderately mentally retarded individuals have learned to devote a considerable amount of effort to hiding their disability.").

89 See ABA Criminal Justice Mental Health Standard 7-2.8 (Specialized training) (providing standards for the training for personnel in "identifying and responding to incidents 
police officers, lawyers, and judges to recognize disabled people has been well documented. For example, "[o]ne study involving 100 police officers, 75 lawyers, and 35 judges found that ' ... while criminal justice system personnel may have some understanding of mental retardation, they are confused and uncertain about how to deal with this population."”

This confusion can influence how these actors interpret the behavior and statements of mentally retarded suspects. Arresting officers may interpret a retarded suspect's failure to make a telephone call as an indication that he does not want to call anyone, even when the failure to act is a product of the suspect's disability. Perhaps the suspect cannot remember the telephone number of a friend or family member, cannot read the telephone book, or is simply unable to operate a telephone."

Even this brief overview of common characteristics displayed by mentally retarded suspects demonstrates why they may be susceptible to the pressures of interrogation. The methods employed by police interrogators inevitably, even if unintentionally, exploit these personal vulnerabilities.

\section{Contemporary Interrogation Techniques and Mentally Retarded Suspects}

The set of common psychological characteristics exhibited by mentally retarded people makes them particularly vulnerable to the pressures exerted by custodial interrogation. As a result, they are more likely to execute a waiver that is not voluntary, knowing, or intelligent in any meaningful sense of those words. Even more troubling, when mentally retarded people are confronted with common interrogation techniques, their personal characteristics increase the likelihood of false confessions.

One of the difficulties faced by anyone attempting to analyze custodial interrogations is verifying the methods actually used by interrogators. The Miranda Court responded to this problem by relying upon police training manuals as sources of authoritative descriptions of interrogation theories and methods. ${ }^{2}$ Obviously this approach is far from ideal. As critics have pointed out, the contents of

involving mentally ill or mentally retarded persons.").

90 Bowker, 63 FBI L Enforcement Bull at 12 (cited in note 40), quoting J. Schilit, The Mentally Retarded Offender and Criminal Justice Personnel, The Council for Exceptional Children at 16 (1979).

91 See generally Dennis E. Haggerty, et al, An Essay on the Legal Rights of the Mentally Retarded, 6 Fam L Q 59, 59-60 (1972) (offering an example of how a retarded person can be questioned without the interviewer realizing the person's retardation).

92 Miranda, 384 US at 448-55. 
these manuals may bear little or no relationship to how police conduct any individual interrogation. Despite the obvious limitations of this method, both the Miranda majority and subsequent commentators have found these manuals to be a useful source of information about how police are trained to interrogate suspects. For the present study, which emphasizes the cognitive capacity of mentally retarded suspects to understand and utilize the warnings rather than the impact of interrogation methods on voluntariness, these manuals provide an adequate description of standard interrogation techniques.

Even a cursory look at the interrogation techniques described in these manuals reveals why mentally retarded suspects are particularly vulnerable to standard techniques and tactics. For example, the leading text instructs that every suspect has weaknesses and recommends interrogation techniques designed to exploit those weaknesses. $^{\text {.4 }}$ One technique encourages interrogators to try to establish a position of authority and then endeavor to convince the suspect, sometimes with the aid of deceptive strategies, ${ }^{95}$ that the police are convinced of the suspect's guilt. By positing the suspect's guilt as a fact, the interrogators hope to undermine his will to resist. The interrogator cuts off a suspect's denials of guilt and dismisses and discourages exculpatory explanations. The interrogator emphasizes the reasons why the suspect committed the act, rather than asking the suspect whether he did it." Given the exaggerated tendency of mentally retarded people to try to accommodate the perceived wishes of authority figures, it is not difficult to appreciate that mentally retarded suspects are particularly vulnerable to these techniques for dominating or deceiving suspects, ${ }^{\$ 8}$ even when interrogators are unaware of a suspect's disability."

93 See, for example, White, 32 Harv CR-CL L Rev at 105, 118 (cited in note 34) ("As the standard police manuals explain, the purpose of interrogation techniques is to exploit [ ] weakness."). See also Gisli H. Gudjonsson, The Psychology of Interrogations, Confessions and Testimony 2, 24 (John Wiley \& Sons 1992) (examining "the various aspects of investigative interviewing" with focus upon practice in England, including discussion of "the tactics and techniques advocated by practical interrogation manuals").

94 Inbau, et al, Criminal Interrogation (cited in note 79).

95 For a critical examination of the use of deceptive interrogation techniques, see White, 32 Harv CR-CL L Rev at 118-20 (cited in note 34).

96 See Inbau, et al, Criminal Interrogation at 60 (cited in note 79) (discussing the effects of assuming the guilt of the person interrogated). See also Miranda, 384 US at 455 ("To be alone with the subject is essential to prevent distraction and to deprive him of any outside support. The aura of confidence in his guilt undermines his will to resist. He merely confirms the preconceived story the police seek to have him describe.").

97 See Inbau, et al, Criminal Interrogation at 60-61 (cited in note 79). See also Miranda, 384 US at 450 ("These tactics are designed to put the subject in a psychological state where his story is but an elaboration of what the police purport to know already - that he is guilty.").

98 See Inbau, et al, Criminal Interrogation at 60-76 (cited in note 79) (stating that the goal of police interrogation is to put the defendant in such an emotional state as to impair his or her 
Even a suspect who has nothing to conceal is likely to experience anxiety as a result of the dynamics of the interrogation process. A suspect who tries to explain his innocence will, at the very least, experience anxiety associated with arguing with a strong authority figure who adamantly refuses to accept, or even to listen, to his position. This anxiety may be heightened by the fact that interrogations often are conducted in private. The police training manuals stress that privacy is a principal psychological factor contributing to a successful interrogation. To be alone with the suspect is essential to prevent distraction and to deprive him of any outside support. Privacy helps the interrogator keep the suspect off balance, for example, by exploiting his insecurity about himself or his surroundings. Although exhibiting "kindness" and understanding of the suspect's situation are basic techniques, training manuals also recommend alternating these techniques with shows of some hostility. One well-known ploy is "good cop-bad cop,"100 a technique likely to exploit a mentally retarded defendant's inability to understand the adversarial nature of the interrogation. The suspect's intellectual limitations create a complementary problem: the inability to understand the very warnings intended to counteract the pressures of interrogation.

\section{The CONSTItutional RULES GOVERning CONFESSIONS}

The Miranda Court concluded-and the Dickerson opinion confirmed -that the traditional method for judging the voluntariness of confessions, the "totality of the circumstances" test, was inadequate to ensure that the privilege against compelled self-incrimination was not trampled by the pressures inherent in custodial interrogation. ${ }^{101}$ The substitute mechanism adopted by the Miranda Court rested upon the implicit assumption that the targets of custodial interrogation possess the intellectual and social competence necessary to utilize this mechanism. The results of this study reveal that the Court's assumption is invalid for mentally retarded people who, because of

capacity for rational judgment; that every suspect has weaknesses; and recommending interrogation techniques designed to exploit those weaknesses.).

99 See id at 60 (describing the techniques and how an average innocent person would react to them).

100 See id at 151-52 (describing such ploys). See also Miranda, 384 US at 452 (noting that the police manual recommends having two agents, one who is "relentless" and "who knows the subject is guilty," and the other who is "obviously a kindhearted man," the idea being that the subject will cooperate with the friendly officer).

101 See Dickerson, 530 US at 442 ("In Miranda, the Court noted that reliance on the traditional totality-of-the-circumstances test raised a risk of overlooking an involuntary custodial confession. ... The Court therefore concluded that something more than the totality test was necessary."). 
their intellectual, psychological, and social limitations, are the group most in need of help to withstand those pressures. In this Part, we will examine the fundamental and still (after more than a third of a century) unproven assumptions upon which the Miranda opinion rests.

\section{A. Constitutional Rules and Miranda}

The Miranda opinion synthesized two separate but interconnected lines of constitutional rules. The first was the constitutional prohibition of compelled confessions, the second was the test for waivers of constitutional rights. The recurring debates spawned by the Miranda decision have focused so often on its dramatic treatment of the issue of coercion that the significance of this synthesis is easily overlooked. From a theoretical perspective this is surprising, because the synthesis rested upon an untested, unverified, and unproven assumption about the Miranda warnings: the Court assumed that they work. This is an assumption that, as it is applied to mentally retarded people, is challenged directly by the empirical results produced by our study. To understand the nature of the synthesis and its significance for mentally retarded suspects, a brief review of the Court's confession jurisprudence will be helpful.

For most of the century preceding the Miranda opinion, the most important developments in the Supreme Court's confession jurisprudence turned on the question of the voluntariness of a suspect's statement. In a series of nineteenth-century opinions, the Court relied upon common law rules ${ }^{102}$ and the Fifth Amendment ${ }^{103}$ to

102 See, for example, Hopt $v$ Utah, 110 US 574, $584-87$ (1884) (holding that admitting a confession is permissible if "voluntary and uninfluenced by hopes of reward or fear of punishment"). See also Dickerson, 530 US at 433 (noting that the roots of the voluntariness test developed in the common law, as the English and United States courts "recognized that coerced confessions are inherently untrustworthy," and citing numerous English cases, including King $v$ Rudd, 1 Leach 115, 117-18, 122-23, 168 Eng Rep 160, 161, 164 (KB 1783) (Lord Mansfield) (stating that the English courts excluded confessions obtained by threats and promises); King $v$ Warickshall, 1 Leach 262, 263-64, 168 Eng Rep 234, 235 (KB 1783) ("A free and voluntary confession is deserving of the highest credit, because it is presumed to flow from the strongest sense of guilt ... but a confession forced from the mind by the flattery of hope, or by the torture of fear, comes in so questionable a shape ... that no credit ought to be given to it; and therefore it is rejected."); King v Parratt, 4 Car \& P 570,172 Eng Rep 829 (NP 1831).

103 See, for example, Bram v United States, 168 US 532, 542 (1897) ("In criminal trials, in the courts of the United States, wherever a question arises whether a confession is incompetent because not voluntary, the issue is controlled by that portion of the Fifth Amendment ... commanding that no person 'shall be compelled in any criminal case to be a witness against himself"); Brown v Walker, 161 US 591, 597 (1896) ("[A] maxim, which in England was a mere rule of evidence, became clothed in this country with the impregnability of a constitutional enactment."). See also Pierce v United States, 160 US 355, 357 (1896) ("Confessions are not rendered inadmissible by the fact that the parties are in custody, provided that such confessions are not extorted by inducements or threats."). 
prohibit the use of involuntary confessions. ${ }^{104}$ In federal cases, the Fifth Amendment provided an explicit textual basis for excluding selfincriminatory statements that were extracted from the suspect by coercive pressure. $^{105}$

The Court did not reverse a state court conviction on the grounds that it was based upon a coerced confession until its landmark 1936 decision in Brown $v$ Mississippi. ${ }^{106}$ The Court held that the three defendants in Brown had been denied due process under the Fourteenth Amendment because their convictions and death sentences were based primarily upon confessions that were the product of physical torture.

In the three decades that followed Brown, the Supreme Court decided about three dozen confession cases, but most were governed by the Fourteenth Amendment, not the Fifth. Chief Justice Rehnquist's opinion in Dickerson summarized this case law succinctly:

Prior to Miranda, we evaluated the admissibility of a suspect's confession under a voluntariness test. . . . Over time, our cases recognized two constitutional bases for the requirement that a confession be voluntary to be admitted into evidence: the Fifth Amendment right against self-incrimination and the Due Process Clause of the Fourteenth Amendment. ${ }^{100}$

He then noted that "for the middle third of the 20th century our cases based the rule against admitting coerced confessions primarily, if not exclusively, on notions of due process. We applied the due process voluntariness test in 'some 30 different cases decided during the era." "109

The due process test developed in these cases considered "the totality of all the surrounding circumstances-both the characteristics of the accused and the details of the interrogation." totality-of-the-circumstances test, courts examined "[a]11 the

104 See Bram, 168 US at 549 (noting that a confession is admissible if proof is "sufficient to establish that the making of the statement was voluntary ... [and] the accused was not involuntarily impelled to make a statement, when but for the improper influences he would have remained silent.").

105 At the time, constitutional theory precluded imposition of the Bill of Rights upon the states. Barron v Mayor of Baltimore, 7 Pet 243, 250 (1833).

106297 US 278 (1936).

107 Id at 284-87 ("It would be difficuit to conceive of methods more revolting to the sense of justice than those taken to procure the confessions of these petitioners.").

108 Dickerson, 530 US at 432-33 (citing Bram and Brown).

109 Id at 433-34 (referring to the period between its decisions in Brown and Escobedo $v$ Illinois, 378 US 478 (1964), and citing several other state cases decided during this period, including Haynes $v$ Washington, 373 US 503 (1963); Ashcraft v Tennessee, 322 US 143 (1944); Chambers v Florida, 309 US 227 (1940)), quoting Schneckloth v Bustamonte, 412 US 218, 223 (1973).

110 Schneckloth, 412 US at 226. 
circumstances attendant upon the confession," confession if "all the attendant circumstances indicate that the confession was coerced or compelled."

By definition, this was a fact-sensitive, case-by-case method of adjudication. It was "retail" constitutional decisionmaking that produced few global rules. Nonetheless, over time the cumulative effect of this process appeared to influence police practices. In Brown, investigators tortured the suspects until they confessed. Twenty years later, the claims of coercion raised in the Supreme Court's confession cases typically alleged less egregious police misconduct. Suspects were not whipped or hanged as they had been in Brown, but abusive practices continued. Suspects were held incommunicado for days; subjected to lengthy interrogations without respite; denied sleep, food, and medical care; and forced to confess to avoid being turned over to an apparent lynch mob. ${ }^{13}$

These methods were less abusive than the torture reported in the $1930 \mathrm{~s}^{114}$ Nonetheless, the facts of these cases also demonstrated that in the 1950s and 1960s, investigators continued to use coercive techniques to pressure suspects to confess. The incremental process of change embedded in the due process methodology was too gradual for some justices, ${ }^{115}$ and as early as the late 1940s the Court began to

111 Reck v Pate, 367 US 433, 440 (1961) ("There is no guide to the decision in cases such as this except the totality of the circumstances."). See also Gallegos v Colorado, 370 US 49, 55 (1962).

112 Malinski v New York, 324 US 401, 404 (1945).

113 Chief Justice Rehnquist's majority opinion in Colorado $v$ Connelly, 479 US 157, 163 n 1 (1986), lists several of these cases:

Reck v. Pate, 367 U.S. 433 (1961) (defendant held for four days with inadequate food and medical attention until confession obtained); Culombe v. Connecticut, 367 U.S. 568 (1961) (defendant held for five days of repeated questioning during which police employed coercive tactics); Payne v. Arkansas, 356 U.S. 560 (1958) (defendant held incommunicado for three days with little food; confession obtained when officers informed defendant that Chief of Police was preparing to admit lynch mob into jail); Ashcraft v. Tennessee, 322 U.S. 143 (1944) (defendant questioned by relays of officers for 36 hours without an opportunity for sleep).

114 Over the decades, the Court's case law also was influenced by the findings of the Wickersham Commission, which confirmed the widespread use of the "third degree" by police officers throughout the country to obtain confessions. See Wickersham Commission, Report on Lawlessness in Law Enforcement 38-155 (1931). See also Miranda, 384 US 436, $445-47$ (1966) (citing the Wickersham Report for evidence of the "third degree").

115 See George E. Dix, Federal Constitutional Confession Law: The 1986 and 1987 Supreme Court Terms, 67 Tex L Rev 231, 235-36 (1988). Two other reasons motivated the Supreme Court to abandon the voluntariness standard. First, the Supreme Court "had been unable to stimulate sufficient lower-court awareness of the voluntariness doctrine's underlying concerns," especially the Court's increasing sensitivity to the risks that police practices posed to values protected by the federal constitution. Id at 235. Second, "the confession problem had outgrown the voluntariness rule. As the Court encountered fewer cases of physical coercion, its concern progressed to the more subtle risks that interrogation practices posed to constitutional values." Id at 235-36. Voluntariness analysis, "perhaps an efficient weapon against overt coercion, was far 
grope for rule-based methods for eliminating abusive interrogation tactics. ${ }^{116}$ The Court's efforts to find more comprehensive rules to regulate police practices intensified in the 1960s.

Only two years before Miranda, the Court decided three cases that moved haltingly toward a more global set of interrogation rules. In two of these cases, the Court relied upon the Sixth Amendment." Neither of these decisions involved the Fifth Amendment, but they foreshadowed the Miranda decision's emphasis upon the importance of defense counsel during custodial interrogation. The third of these 1964 decisions played a more direct role in laying the doctrinal foundations for Miranda. In Malloy v Hogan, ${ }^{118}$ the Court held that the Fifth Amendment's Self-Incrimination Clause was incorporated in the Due Process Clause of the Fourteenth Amendment and binding upon

less effective when applied to psychological ploys." Id at 236.

116 The first attempt at devising a broad prophylactic rule was the "prompt appearance" rule, which was justified by evidence that most abusive interrogations occur in the period between arrest and the suspect's first appearance before a judicial officer. Eventually the McNabb-Mallory rule was devised as a nonconstitutional rule that rested upon the Court's supervisory powers within the federal judicial system. As a result, it did not apply within the state systems. This principle is now embodied in Rule 5(a) of the Federal Rules of Criminal Procedure. See also McNabb v United States, 318 US 332, 339-40 (1943) (holding that judicial supervision in the federal courts implies a duty to set aside convictions based on abusive interrogations); Mallory v United States, 354 US 449, 451-54 (1957) (applying Rule 5(a) and discussing its justifications). Miranda, 384 US at 463 , praised the prompt appearance rule's effect upon coercive interrogations:

Because of the adoption by Congress of Rule 5(a) of the Federal Rules of Criminal Procedure, and this Court's effectuation of that Rule in $M c N a b b$ v. United States ... and Mallory v. United States, we have had little occasion in the past quarter century to reach the constitutional issues in dealing with federal interrogations. These supervisory rules, requiring production of an arrested person before a commissioner "without unnecessary delay" and excluding evidence obtained in default of that statutory obligation, were nonetheless responsive to the same considerations of Fifth Amendment policy that unavoidably face us now as to the States. In $M c N a b b \ldots$ and in Mallory ... we recognized both the dangers of interrogation and the appropriateness of prophylaxis stemming from the very fact of interrogation itself.

117 The first opinion decreed that defendants have the right to have an attorney present during any "critical period" of the proceedings, including confrontations between defendants and undercover agents for the state, in all cases once formal adversarial proceedings had commenced. Relying on the Sixth Amendment right to counsel, the Court suppressed statements made to an undercover informer about crimes for which the defendant already had been indicted. Massiah v United States 377 US 201, 204, 207 (1964). In the second case, the defendant made incriminating statements during custodial interrogation, but before the commencement of formal adversarial proceedings. Once again the Sixth Amendment provided the constitutional basis for the decision. In an opinion that, in retrospect, looks like a bridge between the fact-based totality-of-the-circumstances approach and the creation of global rules in Miranda, the Court suppressed the defendant's confession because police had taken him into custody, had made him the focus of the investigation, and had refused to allow him to meet with his attorney. Escobedo $v$ Illinois, 378 US 478, 490-91 (1964).

118378 US 1 (1964). 
the states. ${ }^{119}$ This allowed the Miranda Court to define Fifth Amendment rules governing both federal and state interrogations. ${ }^{120}$

The best-known parts of the Miranda opinion addressed the issues of voluntariness and coercion. The Miranda majority concluded that modern methods of custodial interrogation were inherently coercive, and that the traditional voluntariness analysis was inadequate to preserve Fifth Amendment rights against the inevitable pressures of this process. ${ }^{121}$ Its most controversial holding was that the Constitution requires implementation of procedures to ensure that these rights are effectively protected from this coercion, and to reassure courts that confessions are, in fact, voluntary. ${ }^{120}$ Miranda's solution was, of course, to replace the multifactored voluntariness analysis with bright line rules built around the now familiar warnings. Prior to custodial interrogation, ${ }^{123}$ the suspect must be advised that he has the right to remain silent, that anything he says can be used against him in court, ${ }^{124}$ that he has the right to an attorney, ${ }^{125}$ and that if he cannot afford an attorney, one will be appointed for him. ${ }^{126}$

The Miranda opinion offered various reasons for abandoning the traditional voluntariness test for confessions. ${ }^{127}$ One is particularly

119 Id at 6-11. See also Dickerson, 530 US at 434 (listing cases relying on the Fourteenth Amendment in requiring voluntariness in confessions).

120 The Sixth Amendment right to counsel was incorporated into the Due Process Clause of the Fourteenth Amendment and imposed upon the states in Gideon v Wainwright, 372 US 335, 341-42 (1963).

121 It is important to recognize, however, that Miranda can be seen as an application of the traditional requirement of voluntariness; it is merely an attempt to ensure that every confession produced in the specific context of custodial interrogation is voluntary. From this perspective, Miranda did not abandon the commitment to voluntariness, rather, it redefined the preconditions for voluntary confessions in a particular setting. As Chief Justice Rehnquist wrote for the Court in Dickerson, 530 US at 434: "We have never abandoned this due process jurisprudence, and thus continue to exclude confessions that were obtained involuntarily. But our decisions in Malloy v. Hogan ... and Miranda changed the focus of much of the inquiry in determining the admissibility of suspects' incriminating statements."

122 Miranda, 384 US at 458.

123 "[Custodial interrogation refers to] questioning initiated by law enforcement officers after a person has been taken into custody or otherwise deprived of his freedom of action in any significant way." Id at 444.

124 The Court explained that only through awareness of these consequences can there be any assurance of real understanding and intelligent exercise of the privilege against selfincrimination. Id at 468.

125 Id at 469 (holding that "[ $t]$ he circumstances surrounding in-custody interrogation can operate very quickly to overbear the will of one merely made aware of his privilege by his interrogators. Therefore, the right to have counsel present at the interrogation is indispensable to the protection of the Fifth Amendment privilege under the system we delineate today.").

126 Id at 473.

127 The Court acknowledged that it was departing from the traditional "totalities" approach. See, for example, id at 457:

In these cases, we might not find the defendants' statements to have been involuntary in traditional terms. Our concern for adequate safeguards to protect precious Fifth Amendment rights is, of course, not lessened in the slightest. In each of the cases, the 
relevant to analysis of confessions by mentally retarded suspects. The Court concluded that the totality-of-the-circumstances analysis was simply an ineffective mechanism for preserving Fifth Amendment rights. ${ }^{123}$ In Dickerson, the Court explained:

In Miranda, the Court noted that reliance on the traditional totality-of-the-circumstances test raised a risk of overlooking an involuntary custodial confession, ... a risk that the Court found unacceptably great when the confession is offered in the case in chief to prove guilt. The Court therefore concluded that something more than the totality test was necessary. ${ }^{129}$

This conclusion leads us to the fundamental assumption upon which the Miranda opinion's solution to the problem of coercion rests. In Miranda, the Court assumed, without offering any supporting evidence, that the litany of warnings actually work; that they provide suspects subjected to the pressures of custodial interrogation with means adequate to preserve the constitutional privilege against compelled self-incrimination. ${ }^{130}$ Chief Justice Warren's opinion recited the bald conclusion that the warnings constituted "fully effective means ... to inform accused persons of their right of silence and to ... exercise it." ${ }^{131}$

This conclusion is erroneous, at least when extended to mentally retarded people. This error results in part from the Miranda majority's adoption of the "voluntary, knowing, and intelligent" waiver test

defendant was thrust into an unfamiliar atmosphere and run through menacing police interrogation procedures. The potentiality for compulsion is forcefully apparent.

128 See Dickerson, 530 US at $440 \mathrm{n} 6$ ("[A] review of our opinion in Miranda clarifies that this disclaimer was intended to indicate that the Constitution does not require police to administer the particular Miranda warnings, not that the Constitution does not require a procedure that is effective in securing Fifth Amendment rights"); id at 442 (explaining that even when supplemented by additional remedies not available at the time Miranda was decided, the totality-of-the-circumstances approach resurrected in 18 USC $\$ 3501$ (1994) is not "an adequate substitute for the warnings required by Miranda").

129 Id at 442, citing Miranda, 384 US at 457, 467, 490-91. This risk was in part the product of a second defect: totality-of-the-circumstances analysis precluded the drawing of bright lines. Totality-of-the-circumstances analysis was too imprecise, and the Court had recognized this problem even before Miranda: "The line between proper and permissible police conduct and techniques and methods offensive to due process is, at best, a difficult one to draw." Haynes v Washington, 373 US 503, 515 (1963).

130 See Miranda, 384 US at 444 (holding that the prosecution cannot use the confession "unless it demonstrates the use of procedural safeguards effective to secure the privilege against self-incrimination"); id (holding that warnings must be given unless the government used other methods that were also "fully effective"); id at 458 (holding that the government must use "adequate protective devices ... to dispel the compulsion inherent in custodial surroundings"); id at 467 ("However, unless we are shown other procedures which are at least as effective in apprising accused persons of their right of silence and in assuring a continuous opportunity to exercise it, the following safeguards must be observed.").

131 Id at 444. 
enunciated nearly thirty years earlier in the context of waivers of the right to counsel. ${ }^{132}$ The waiver test has two dimensions. The first requires that the waiver must be voluntary, a "free and deliberate choice," and not compelled by government pressure. The second commands that a waiver must be knowing and intelligent, a test that is met if the person comprehends the nature of the right and the consequences of abandoning it. ${ }^{133}$

Miranda assumed that a suspect who received the warnings not only would possess information that would ensure that a subsequent waiver was "knowing and intelligent," but also that this knowledge supplied the tools necessary to counteract the pressures of custodial interrogation, thus ensuring that a confession was "voluntary." Because these assumptions were applied to enforce the constitutional ban on compelled confessions, Miranda functionally conflated the two prongs of the waiver test. A confession would be uncoerced if a warned suspect executed a waiver. Yet only by presuming that people will understand the warnings could the Miranda decision purport to create the necessary predicate for a "waiver ... made voluntarily, knowingly, and intelligently., ${ }^{134}$

The Miranda opinion repeatedly asserted the unsubstantiated assumption that the warnings would be effective. It commanded that the prosecution cannot use a confession "unless it demonstrates the use of procedural safeguards effective to secure the privilege against self-incrimination." 135 The warnings were mandatory unless the government used other methods that were also "fully effective." The government must use "adequate protective devices ... to dispel the compulsion inherent in custodial surroundings." ${ }^{137}$ The opinion acknowledged that the specific warnings enunciated in the opinion were not the only possible means of providing protection beyond that offered by the totalities analysis: "However, unless we are shown other procedures which are at least as effective in apprising accused persons of their right of silence and in assuring a continuous opportunity to exercise it, the following safeguards must be observed."

One will search the Miranda opinion in vain for evidence supporting the assumption that the warnings not only are more effective than the totalities approach, but are adequate to ensure that

132 Id at 475. This is an application of the well-known standard for waivers of constitutional rights enunciated in Johnson v Zerbst, 304 US 458, 464 (1938).

133 Moran v Burbine, 475 US 412, 421 (1986).

134 Miranda, 384 US at 444.

135 Id at 444.

$136 \mathrm{Id}$.

137 Id at 458.

138 Id at 467. 
waivers are knowing, intelligent, and voluntary. In fact, the only evidence the majority offered about the likely impact of the warnings supported a very different proposition. The majority opinion devoted nearly seven pages (more than 10 percent of the text of the majority opinion) to establishing that the prior use of similar warnings both by the FBI and in foreign jurisdictions had not impeded law enforcement. ${ }^{139}$

In subsequent opinions, the Supreme Court has reiterated its unsubstantiated assumption that cognitive understanding supplied by the information contained in the warnings assures that all parts of the waiver test are satisfied. After more than two decades of experience with Miranda, the Court wrote:

The Fifth Amendment's guarantee is both simpler and more fundamental: A defendant may not be compelled to be a witness against himself in any respect. The Miranda warnings protect this privilege by ensuring that a suspect knows that he may choose not to talk to law enforcement officers, to talk only with counsel present, or to discontinue talking at any time. The Miranda warnings ensure that a waiver of these rights is knowing and intelligent by requiring that the suspect be fully advised of this constitutional privilege, including the critical advice that whatever he chooses to say may be used as evidence against him. ${ }^{10}$

More recently, Chief Justice Rehnquist's opinion in Dickerson reasserted the assumption that the warnings are "effective." Dickerson opinion invalidated the congressional attempt to overrule Miranda in part because the totality-of-the-circumstances analysis enacted in 18 USC $\$ 3501$ was not "equally as effective in preventing coerced confessions." ${ }^{142}$ Rejecting arguments that language in Miranda revealed that the warnings were but prophylactic devices, Dickerson concluded that this language "was intended to indicate that the Constitution does not require police to administer the particular Miranda warnings, not that the Constitution does not require a procedure that is effective in securing Fifth Amendment rights." ${ }^{143}$

The assumption that the warnings are effective is fundamental to the entire Miranda construct. The assumption of effectiveness rested, in turn, upon the underlying presumption that suspects would

\footnotetext{
139 Id at 483-90.

140 Colorado v Spring, 479 US 564, 574 (1987).

141 Dickerson, 530 US at 440 (quoting Miranda's description of possible alternatives to the warnings that were "at least as effective in apprising accused persons of their right of silence and in assuring a continuous opportunity to exercise it") (emphasis added).

142 Id at 441 (citations omitted) (emphasis added).

143 Id at 440 n 6 (emphasis added).
} 
understand both the meaning and the legal significance of the warnings. ${ }^{14}$ Without this assumption of understanding, the warnings could not logically serve as the predicate for a knowing and intelligent waiver. Without this assumption, the Court could not justify its decision to abandon the traditional totality-of-the-circumstances approach to judging the voluntariness of confessions. And the Miranda majority apparently expected that the warnings would be effective for everyone-even mentally retarded suspects.

The Court must have contemplated that these warnings would be applied to interrogations of suspects with subaverage intelligence, because the Miranda opinion expressly mentions at least two such cases. These passages indicate that the Court not only was conscious of the increased vulnerability of mentally retarded people to the pressures of custodial interrogation, but also was aware that their weaknesses might lead them to confess to crimes they did not commit. In the first passage, the Court noted:

Even without employing brutality, the 'third degree' or the specific stratagems described above, the very fact of custodial interrogation exacts a heavy toll on individual liberty and trades on the weakness of individuals. This fact may be illustrated simply by referring to ... Townsend $v$. Sain, [where] the defendant was a 19-year-old heroin addict, described as a 'near mental defective.,

The Court's awareness of the vulnerability of disabled suspects to succumb to contemporary interrogation techniques was highlighted by the description of yet another case in which a suspect possessing only "limited intelligence" confessed to two heinous crimes he had not committed:

Interrogation procedures may even give rise to a false confession. The most recent conspicuous example occurred in New York, in 1964, when a Negro of limited intelligence confessed to two brutal murders and a rape which he had not committed. When this was discovered, the prosecutor was reported as saying: "Call it what you want-brain-washing, hypnosis, fright. They made him give an untrue confession. The only thing I don't believe is that Whitmore was beaten., ${ }^{146}$

144 A peripheral result of our study is that it provides limited support for one part of this assumption as it is applied to nondisabled people. The data produced by our study suggest that the control group of nondisabled people understood the warnings. Whether this cognitive understanding would translate into the capacity to resist the coercive pressures of custodial interrogation is untested by our study.

145 Miranda, 384 US at 455-56 (citations omitted) (emphasis added).

146 Id at 455 n 24 (citation omitted). 
Despite this evidence that custodial interrogation might weigh particularly heavily upon mentally retarded suspects, the Miranda majority apparently just assumed that the warnings would be effective means of preserving Fifth Amendment rights for all suspects, regardless of their mental capacities. The results of the study reported in this Article confirm what should be obvious: this assumption is wrong for mentally retarded people. Because cognitive understanding of the content of the warnings is required if the warnings are to fulfill their instrumental functions, a person who is not capable of understanding the warnings logically cannot execute a waiver that is either knowing or intelligent. In an effort to determine whether mentally retarded people possess the mental capacity to waive their rights, courts frequently turn to the totality-of-the-circumstances test rejected in Miranda.

\section{B. Totality of the Circumstances and Mentally Retarded Suspects}

Because mentally retarded people frequently appear as defendants in criminal cases, courts repeatedly have confronted the question of the admissibility of their confessions. In the post-Miranda world, courts have recognized that waivers executed by mentally retarded suspects deserve extra scrutiny to determine if they were in fact voluntary, knowing, and intelligent. In recognition of the seriousness of the problem, many courts have employed a second level of analysis to determine whether confessions by mentally retarded defendants were voluntary. ${ }^{1.7}$ Unfortunately, our data suggest that the most common method courts employ is no more effective than are the warnings themselves at ensuring that waivers by mentally retarded individuals are knowing and intelligent.

Miranda remains the analytical starting point for waivers by mentally retarded suspects. Regardless of the suspect's cognitive capacity, the warnings are required for any confession produced by custodial interrogation. If the suspect was "Mirandized" and no evidence of police overreaching exists, the courts are likely to hold that the waiver was voluntary. ${ }^{14}$ This analysis is unlikely to acknowledge Miranda's assumed relationship between cognitive understanding and voluntariness. ${ }^{\text {u9 }}$ Because of the nature of contemporary interrogation practices-Miranda warnings are typically administered and interrogators employ psychological, not

147 Marvel, 8 ALR 4th at 29-60 (cited in note 27) (collecting relevant cases).

148 See notes $281-90$ and accompanying text.

149 See notes $290-91$ and accompanying text. 
physical, pressure -in the absence of egregious misconduct, courts are likely to find that post-waiver confessions were valid. ${ }^{150}$

There are exceptions. In some cases, the suspects' mental retardation was so severe that courts have concluded that Miranda waivers were invalid. ${ }^{151}$ For most mentally retarded defendants, however, courts treat mental disability as only one factor to be considered as part of the totality of the circumstances. ${ }^{152}$

When courts are confronted with challenges to the voluntariness of confessions by people with developmental disabilities, typically they have returned to a fact-specific, case-by-case, multifactored totality-ofthe-circumstances analysis. From a theoretical perspective, the reemergence of the totality-of-the-circumstances analysis might seem perplexing, because Miranda (and now Dickerson) ${ }^{153}$ rejected this amorphous method as inadequate protection against the pressures inherent in custodial interrogation. ${ }^{154}$ But the empirical results of our study raise even more troubling practical concerns about this method of judging a disabled suspect's cognitive competence to execute a Miranda waiver. They suggest that the totality-of-the-circumstances analysis does not work. ${ }^{155}$ This empirical evidence is significant, because it calls into question the common practices of both federal and state courts.

Although courts may consider any factor they consider relevant when examining the totality of the circumstances, ${ }^{156}$ the cases

150 See, for example, Kamisar, 99 Mich L Rev at 892 nn 54-55 (cited in note 2) (noting difficulties of showing compulsion); Thomas, 99 Mich $L$ Rev at 1101 (cited in note 12) ("When a suspect waives Miranda, the only limitation on police interrogation is the Due Process Clause, the very protection that Miranda found unacceptably parsimonious.").

151 For a comprehensive review of the case law, see Marvel, 8 ALR 4th at 28-29 (cited in note 27) (citing cases addressing the rule that subnormality so great as to vitiate understanding renders confession inadmissible). See also Charles C. Marvel, Mental Subnormality of Accused as Affecting Voluntariness or Admissibility of Confession, 8 ALR 4th 5-6 (Supp 1999) (citing cases relevant to intelligence as a factor to be weighed in evaluating validity of waivers).

152 For a comprehensive review of the case law, see Marvel, 8 ALR 4th at 21-22 (cited in note 27), 24-28 (noting the principle that subnormality is the only factor affecting voluntariness or admissibility); id at 33-35 (reviewing federal court cases involving waiver or understanding of Miranda rights); id at 40-52 (reviewing state court cases).

153 From a theoretical perspective, this reliance upon the totality-of-the-circumstances analysis to judge voluntariness-even as a secondary mechanism-appears to contradict the central premise of the Miranda decision recently affirmed by the Court. See Dickerson, 530 US at 442 ("In Miranda, the Court noted that reliance on the traditional totality-of-thecircumstances test raised a risk of overlooking an involuntary custodial confession... The Court therefore concluded that something more than the totality test was necessary.").

154 See note 101 and accompanying text.

155 See Part IV.

156 See, for example, Correll v Thompson, 63 F3d 1279, 1288 (4th Cir 1995) (examining intelligence, previous experience with police, and previous warnings); Derrick $v$ Peterson, 924 F2d 813,824 (9th Cir 1991) (examining method of waiver, prior experience with police and Miranda, and psychologists' testimony of subject's understanding); West v United States, 399 F2d 467, 469 (5th Cir 1968) (examining defendant's age and education); Coyote v United States, 380 F2d 305, 
demonstrate that courts often focus on five factors when determining the validity of confessions by disabled defendants: the defendant's intelligence, usually as measured by IQ; the defendant's chronological age; the defendant's education; the defendant's previous experience with the criminal justice system; and his previous experience with administrations of the warnings. ${ }^{157}$

In this analysis, no single factor is controlling in determining whether an individual has validly waived his or her rights. The manner in which these factors are to be weighed and evaluated is left to the judge's discretion. ${ }^{158}$ Because the totality-of-the-circumstances test permits the courts to weigh several factors together, it is not always possible to determine which factors caused a court to exclude or admit a confession, and courts rarely indicate the relative importance of the factors that they use. Nonetheless, some general patterns relating to each of these factors have emerged from the case law.

(1) Intelligence. Courts employ intelligence, usually measured by scores on IQ tests, to establish whether a waiver is voluntary, knowing, and intelligent. Courts generally conclude that a defendant's low intelligence is but one factor to be considered, its importance increasing with the degree of the person's mental deficiency. Nonetheless, courts are not consistent in their decisions involving similar IQ scores, and as one would expect from a "totalities" analysis, no clear judicial guidelines have emerged from the case law. For example, in Lavallis $v$ Estelle, ${ }^{1,9}$ a federal district court found that a waiver by a defendant with an IQ of sixty-five was valid. ${ }^{160}$ However, in Smith $v$ Kemp ${ }^{161}$ a different district court found that a waiver executed by a defendant with the same IQ score was invalid. ${ }^{162}$

Despite the absence of consistent guidelines, some patterns appear in the case law. Courts occasionally exclude confessions of suspects with IQs of 60 to 65 or higher when other factors indicate the suspect did not understand the warnings. ${ }^{163}$ In general, however, when

308 (10th Cir 1967) (examining age and intelligence as possible factors to be considered); State $v$ White, 494 SW2d 687, 691 (Mo App 1973) (examining age and previous experience with police), revd, In re $A D R, 603$ SW2d 575, 584 n 7 (Mo 1980) (considering, inter alia, age, experience, education, background, and intelligence).

157 See, for example, Correll, 63 F3d at 1288 (Iooking at all five factors).

158 See, for example, Derrick, 924 F2d at 823, citing Perri v Director of the Department of Corrections of Illinois, $817 \mathrm{~F} 2 \mathrm{~d}$ at 451 (7th Cir 1987) (giving a presumption of correctness to the state court's finding that a waiver was knowing and intelligent); Ahmad v Redman, 782 F2d 409, 412-13 (3d Cir 1986) (discussing the appropriate standard of review in waiver cases).

159370 F Supp 238 (S D Tex 1974).

160 Id at 243-44.

161664 F Supp 500 (M D Ga 1987).

162 Id at 501,505 .

163 See, for example, Jurek $v$ Estelle, 593 F2d 672, 675-77 (5th Cir 1979) (holding defendant's waiver invalid where he had an IQ of 66 , was treated poorly by the police prior to 
the defendant's IQ is 60 to 65 or higher, courts conclude that the defendant understood his rights and uphold a waiver. ${ }^{164}$ Courts appear to assume that a defendant with only mild mental retardation understands his Miranda rights. In contrast, courts are more likely to hold that waivers by suspects with IQs below 60 to 65 are invalid."

(2) Age. Courts often consider the defendant's age when evaluating whether a defendant understood the warnings. Once again, some common patterns emerge from the case law. Courts frequently uphold waivers by defendants over age nineteen, regardless of IQ. For defendants who are sixteen to nineteen years old, courts appear to uphold most, but not all, waivers. They reject most, but not all, waivers for defendants of ages thirteen to fifteen, and reject waivers for defendants who are even younger. ${ }^{160}$

(3) Education. Courts frequently consider the level of education that the defendant has achieved when evaluating his capacity to

confessing, and had a condition that made him especially susceptible to the influence of others); People v Stanis, 41 Mich App 565, 200 NW2d 473, 477-79 (1972) (holding defendant's waiver invalid where he maintained an IQ between 65 to 70 ).

164 See, for example, Correll, 63 F3d at 1291 (waiver valid where defendant had an IQ of 68); Derrick, 924 F2d at 824 (waiver valid where defendant had an IQ of 62); Moore $v$ Dugger, 856 F2d 129, 132 (11th Cir 1988) (waiver valid where defendant had an IQ of 62); Sumpter v Nix, 863 F2d 563, 564-65 (8th Cir 1988) (waiver valid where defendant had an IQ of 89); Fairchild $v$ Lockhart, 744 F Supp 1429, 1461 (E D Ark 1989) (upholding waiver by defendant, rejecting IQ score of 60 obtained by neutral expert selected by prosecution and defense, and instead relying upon IQ score of 75-87 resulting from other IQ tests); United States v Chrans, $696 \mathrm{~F}$ Supp 1210, 1211-12 (N D Ill 1988) (waiver valid where defendant had an IQ of 86); Smith, 664 F Supp at 501, 505 (waiver invalid where defendant had an IQ of 65); Lavallis $v$ Estelle, $370 \mathrm{~F}$ Supp 238, 243 (S D Tex 1974) (waiver valid where defendant's IQ was 65); Jackson v State, 306 Ark 70, 811 SW2d 299, 301 (1991) (waiver valid where defendant's IQ was between 74 and 81); State $v$ Fetters, 202 NW2d 84, 88 (Iowa 1972) (waiver valid where defendant had an IQ of 67); People v Creamer, 143 Ill App 3d 64, 492 NE2d 923, 926, 928 (1986) (waiver valid where defendant had an IQ of 60); People v Ellison, $126 \mathrm{IIl}$ App 3d 985, 466 NE2d 1024, 1029 (1984) (waiver valid where defendant had an IQ of 77); Johnston $v$ State, 455 So2d 152, 156 (Ala App 1984) (waiver valid where defendant had an IQ of 67); Mitchell v State, 338 S2d 524, 525-26 (Ala App 1976) (upholding waiver of defendant who had an IQ of approximately 65).

165 See, for example, United States v Hull, 441 F2d 308, 309, 312 (7th Cir 1971) (holding waiver invalid where defendant had an IQ of 54); Harvey $v$ State, 207 S2d 108, 109-10, 117 (Miss 1968) (holding waiver invalid where defendant had an IQ of 60).

166 See Lopez $v$ United States, 399 F2d 865, 867-68 (9th Cir 1968) (holding that a sixteenyear-old's age did not per se make a waiver involuntary); West, 399 F2d at 470-71 (same); State $v$ Thompson, 287 NC 303, 214 SE2d 742, 752-55 (1975) (upholding finding that a nineteen-year-old mildly retarded defendant validly waived his Miranda rights); In re R., 345 NYS2d 11, 12 (1973) (holding that nine-year-old did not knowingly and intelligently waive his rights); People v Baker, 9 Ill App 3d 654, 292 NE2d 760, 764-65 (1973) (upholding determination that a fifteen-year-old with an IQ of 72 did not knowingly and intelligently waive despite careful explanations by police); In re S.H., 61 NJ 108, 293 A2d 181, 184-85 (1972) (holding that Miranda warnings are meaningless to a ten-year-old); Stanis, $200 \mathrm{NW2d}$ at $477-79$ (holding invalid the waiver of an adult with a mental age of eight); State $v$ Prater, 77 Wash 2d 526, 463 P2d 640, 644 (1970) (holding valid a waiver by a seventeen-year-old familiar with the warnings). For an extensive discussion of courts' evaluation of juveniles' confessions, see generally Grisso, Juveniles' Waiver of Rights at 63 nn 2-4 (cited in note 22) (collecting cases). 
understand the warnings. ${ }^{167}$ Not surprisingly, mentally retarded individuals often have attained relatively low levels of educational achievement. Nonetheless, courts often find that extremely modest academic achievement indicates a capacity to understand the warnings. ${ }^{168}$

(4) Previous encounters with police. Courts frequently cite mentally retarded defendants' prior experience with the criminal justice system as a factor supporting admission of confessions. The courts apparently reason that understanding of the warnings follows from increased experience with the police. For example, in United States $v$ Smith ${ }^{169}$ the court admitted the defendant's confession despite the defendant's low IQ because it determined that the defendant's numerous previous encounters with law enforcement had made him "street-wise and fully conversant with his rights."

(5) Previous warnings. Finally, courts are more likely to decide that a disabled defendant understood the warnings if they had been administered to him on other occasions. For example, in Correll $v$ Thompson, ${ }^{171}$ the court upheld the admission of the confession of a defendant with an IQ of $68 .^{172}$ During the defendant's earlier experiences with law enforcement, police had administered Miranda warnings to him more than twelve times, leading the trial court to characterize him as "streetwise."

167 See, for example, Commonwealth v Youngblood, 453 Pa 225, 307 A2d 922, 924-25 (1973) (supporting, in dictum, the lower court's finding that waiver by a defendant with schizophrenia and a third-grade education was not voluntary); West, 399 F2d at 469 (noting the tenth-grade education of the defendant in holding his waiver valid). See also Grisso, Juveniles' Waiver of Rights at $65 \mathrm{n} 8$ (cited in note 22) (citing cases where "grade levels were used as an index of general intellectual capacity").

168 See Grisso, Juveniles' Waiver of Rights at 65 n 8 (cited in note 22) (collecting cases).

$169574 \mathrm{~F} 2 \mathrm{~d} 707$ (2d Cir 1978).

170 Id at 709. See also Felder $v$ Estelle, 588 F Supp 664, 669 (S D Tex 1984) (holding defendant's waiver valid where he had a history of prior involvement with law enforcement officials and was "likely aware of the consequences of confessing"), revd as Felder v McCotter, $765 \mathrm{~F} 2 \mathrm{~d} 1245$ (5th Cir 1985) (reversing because defendant with low intelligence was questioned outside his attorney's presence); Mealey v State, 347 A2d 651, 652 (Del 1975) (holding that defendant who was a "borderline defective" nonetheless validly waived his Miranda rights because he had been arrested and questioned on prior occasions when police advised him of his rights); Correll, 63 F3d at 1291 (admitting confession of defendant with IQ of 68 because of defendant's earlier contacts with police); Prater, $463 \mathrm{P} 2 \mathrm{~d}$ at 641 (finding that defendant's fifteen prior arrests reduced importance of understanding of warnings; "a warning as to his rights was needless."); In re Morgan, 33 Ill App 3d 10, 341 NE2d 19, 21-22 (1975) ("[I]t is significant that he had previous experience with the police."); White, 494 SW2d at 691 (examining age, previous experience with the police, and noting that physical condition and intelligence are factors, although not on the record in this case).

17163 F3d 1279 (4th Cir 1995).

172 Id at 1288.

173 Id at 1288, 1291. 
Judges employing the totalities test often conclude that a mentally retarded person can knowingly and intelligently waive his Fifth Amendment rights if that person's low IQ is offset by age, education, or previous experience with the police or the warnings." For example, courts frequently find that a mentally retarded defendant understood the warnings if the defendant is an adult, or had a number of years of education, or had prior experience with the police or the warnings. Some evidence exists that these factors may correlate with cognitive understanding by nondisabled people, ${ }^{175}$ but the results of our study lead to a different conclusion for mentally retarded people.

Our empirical results, which we present in Part IV, indicate that even people with only the mildest retardation do not understand the Miranda warnings or their legal significance. In addition, these results reveal that the presence of the factors commonly used in this totalities analysis-age, education, experience with the criminal justice system, experience with the warnings, and the degree of the disability-do not compensate for a subject's lack of understanding resulting from his disability.

The factor that matters is mental retardation. Our study reveals that despite a suspect's prior experience with the police and the warnings, or his age and education, a mentally retarded person will not understand all of the Miranda warnings and their legal significance. The empirical bases for this conclusion are presented in Part IV.

\section{THE EMPIRICAL STUDY}

Our study sought to translate the legal standard for understanding Miranda rights into measures permitting us to evaluate whether test subjects achieved the required level of understanding. Our study's design drew upon extensive and well-accepted existing research by legal experts and social psychologists that measured understanding of Miranda rights by juveniles. ${ }^{176}$ Adapting this work for

174 See Smith, 574 F2d at 709 (holding defendant's waiver valid where he had numerous previous encounters with law enforcement that made him streetwise and fully conversant with his rights, despite the fact that defendant's IQ was admittedly low); Mealey, 347 A2d at 653 .

175 See, for example, Leiken, 47 Denver L J at 18-20 (cited in note 22) (showing that such factors influence nondisabled defendants' understanding of the Miranda rights).

176 Our research design drew heavily upon Grisso's study on the understanding of Miranda rights by juveniles. See Grisso, Juveniles' Waiver of Rights at 41-58, 109-30 (cited in note 22). Other studies that we used in the research design included Grisso, $68 \mathrm{Cal} \mathrm{L} \mathrm{Rev} \mathrm{at} 1143 \mathrm{n} 52$ (cited in note 22); Grisso and Pomicter, 1 L \& Human Beh at 321 (cited in note 22); A. Bruce Ferguson and Alan Charles Douglas, $A$ Study of Juvenile Waiver, 7 San Diego L Rev 39, 40-44, 50-53 (1970) (explaining the methodology behind a study of San Diego juveniles and their comprehension of Miranda warnings). We used Grisso's study as a model because of its careful design and because concerns relevant to mentally retarded defendants mirror those relevant to 
mentally retarded subjects, our approach permitted us to determine both whether this population could understand the Miranda warnings and whether the factors contained in the typical judicial "totality of the circumstances" analysis influenced the subjects' understanding.

\section{A. The Methodology}

1. The test components.

Our study contained three components, each of which investigated an important aspect of understanding of Miranda rights.

a) The Vocabulary Test. Our study's first section was based on the proposition that an individual can make a knowing and intelligent waiver of his Miranda rights only if he understands the words used in the warnings. This section of the study objectively assessed the disabled individual's knowledge of seven key words in the Miranda warnings. The seven words were "consult," "attorney," "interrogation," "appoint," "entitled," "right," and "statement."1"

The testing followed a detailed, scripted protocol. ${ }^{178}$ The examiner began each interview by explaining the directions for the test. The examiner then said each vocabulary word and used it in a sentence in a way unrelated to the criminal justice system. The interviewee was then asked to explain what the word meant. Using a detailed and objective grading protocol, two, one, or zero points of credit were assigned to adequate, questionable, and inadequate responses, respectively. ${ }^{179}$

In addition to testing understanding of the Miranda warnings' actual vocabulary, we tested understanding of a simplified vocabulary. Our goal was to determine whether subjects who might not understand the actual vocabulary of the warnings might understand simplified synonyms. If so, requiring law enforcement officers to administer a simplified warning might be an appropriate policy change. We adapted the synonyms from studies testing simplified warnings on juveniles. ${ }^{180}$ The simplified synonyms were "seek advice,"

juveniles.

177 The words were identical to the words that were tested in the leading study on understanding of the warnings by juveniles, except that we also tested understanding of "statement." Grisso, Juveniles' Waiver of Rights at 237-38 (cited in note 22).

178 The testing and grading protocols are reproduced in the Protocol Appendix following this Article.

179 The testing and grading protocols, which are reproduced in the Protocol Appendix, were based upon earlier well-accepted studies of understanding by juveniles. See Grisso, Juveniles' Waiver of Rights at $237-42$ (cited in note 22).

180 See Larry E. Holtz, Miranda in a Juvenile Setting: $A$ Child's Right to Silence, $78 \mathrm{~J}$ Crim L \& Criminol 534, 553-56 (1987) (proposing a simplified "Youth Rights Form"); Ferguson and Douglas, 7 San Diego L Rev at 39-40, 43-44 (cited in note 176) (testing the effectiveness of simplified warnings on juveniles' understanding of their Miranda rights). 
"lawyer," "questioning," "choose," "deserve," "choice," and "your story."

b) The Warnings Test. As noted earlier, the Miranda opinion requires that a waiver of a suspect's rights be "voluntary, knowing, and intelligent." Courts have proclaimed that this standard requires that the suspect understands "both the nature of the right being abandoned and the consequences of the [waiver]." ${ }^{181}$ In the second section of the study, we attempted to determine whether mentally retarded subjects could comprehend the principles embodied in the warnings. Even if a subject understands the meanings of the individual words that make up the Miranda warnings, it is possible that the subject will not understand the principles that the words express together. The Warnings Test evaluated the subject's understanding of each of the four sentences of the warnings as phrased by the Supreme Court. The test measured understanding in two ways. First, the test investigated the subject's ability to determine whether a given statement had the same meaning as a specified sentence in the warnings. Second, the test asked a series of yes/no questions about each of the sentences comprising the Miranda warnings.

The interviewer began the "same/different" portion of the test by placing a card with a sentence from the Miranda warnings in front of the interviewee and reading the sentence aloud. The interviewer then placed a card with a second sentence in front of the interviewee and read it aloud. The interviewee was asked to determine whether the sentences had the same or different meanings. For example, after reading the subject the Miranda warnings' first sentence, "You do not have to make a statement and have the right to remain silent," the interviewer asked the subject whether the following sentence was the same or different: "You do not have to say anything about what you did." Using a detailed grading protocol, the interviewer gave the subject a score of one for a correct answer and zero for a wrong answer. In total, the interviewer presented the subject with three same/different sentence comparisons for each of the four sentences of the warnings. ${ }^{12}$

181 Moran v Burbine, 475 US 412, 421 (1986). See also Johnson v Zerbst, 304 US 458, 464 (1938) ("A vaiver is ordinarily an intentional relinquishment or abandonment of a known right or privilege.") (emphasis added).

182 The sentences were identical to those in the seminal study of juveniles' understanding. Grisso, Juveniles' Waiver of Rights at 235-36 (cited in note 22). Before administering this part of the test, the interviewer assessed whether the interviewee was capable in general of determining whether two sentences mean the same thing or different things. The interviewer went through an example with a sentence unrelated to the warnings. If the interviewee was able to discern whether the meanings of those sentences were the same or different, then the interviewer administered the entire Warnings Test. If the interviewee was unable to determine whether the meanings of the sentences were the same or different, then the interviewer only gave the yes/no 
Next, the examiner asked the subject three yes/no questions about each of the four sentences comprising the Miranda warnings. A score of one was given for correct answers and zero was given for incorrect answers. The sentences tested the subject's bottom-line understanding of each of the Miranda rights. For example, after reading the subject the first Miranda sentence, the interviewer asked, "Do you have to tell the police what happened?" and "Do you have to answer the police if they ask you any questions?"

c) The Concepts Test. The premise of our study's third section was that even if a person can understand both the Miranda vocabulary and sentences, nonetheless she will be unable to waive her rights voluntarily, knowingly, and intelligently if she lacks understanding of the legal context within which the rights operate. For example, the Miranda warnings are of little practical use to a person who fails to understand either that an investigating police officer may be the her adversary or that the her attorney is her advocate rather than adversary. The Concepts Test investigated whether the subject had the basic understanding of the criminal justice system that is necessary to use the rights.

The Concepts Test had questions that addressed three topics. First, the "Nature of Interrogation" questions examined whether the subject understood the purpose of the interrogation and the roles and incentives of the participants in it. For example, the questions tested whether the subject understood both that the police believed that a crime was committed and that they were seeking information from the suspect. Next, the "Right to Counsel" questions investigated whether the subject understood the role of defense attorneys. For example, they tested whether the subject understood that the attorney was his advocate. Finally, the "Right to Silence" questions examined the subject's understanding of the meaning of the right to silence. For example, the questions explored whether the subject understood that neither the judge nor the police could require a suspect to speak or penalize silence.

portion of the test and scored the same/different section as all zeros.

183 The interviewer began the Concepts Test by reading directions to the interviewee. The interviewer then placed a drawing of a scene in front of the interviewee and told a scripted story about the picture. The interviewer then asked the interviewee questions about the scene. The first scene depicted a person being interrogated by the police. The questions related to the understanding of the nature of interrogation. The second scene depicted a person meeting with his lawyer in a consulting room in the police station. The questions regarding this scene all related to the subject's understanding of the function and significance of the right to counsel. The third scene depicted a person entering an interrogation room with two police officers. The questions for this scene related to the function and significance of the right to silence. The last scene depicted a courtroom hearing, with a judge, police officers, parents or guardian, the individual's lawyer, and the individual. The questions for this scene focused on the function of both the right to counsel and the right to silence. The scoring of the responses to the questions 
2. Procedure for finding mentally retarded subjects.

We sought to find mentally retarded interviewees who had both a range of severity of disabilities and variety in age, education, experience with police, race, and gender. We contacted a number of organizations that serve different mentally retarded populations. ${ }^{184}$ These organizations sent a letter, which we had drafted, to all of their members or clients. The letter described the study and asked for volunteer participation. We identified some volunteer interviewees directly through the organizations. We arranged others through the mentally retarded individuals' parents or guardians. In total, we conducted forty-nine interviews with people with mental retardation. Each interview took one to three hours, depending on the subject's communication ability.

In order to determine what factors are important to an individual's understanding of his Miranda rights, the interviewer collected demographic information from each mentally retarded volunteer. The information from each volunteer included: (1) IQ, (2) age, (3) education level, (4) experience with police, (5) previous experience with the Miranda warnings, (6) race, and (7) gender. ${ }^{185}$

As Figure 1 shows, the levels of retardation among our subjects varied widely. Although the average IQ was 55.5, which parallels the categories of mild to moderate retardation, our sample included a range of IQs. Of the sample, 18 percent were either profoundly or severely disabled, 25 percent were moderately disabled, and 35

was two for an adequate response, one for a questionable response, and zero for an inadequate response. See Protocol Appendix Parts III and IV.

184 Participating organizations included the Atlanta Jewish Developmental Disabilities Department, Resources and Residential Alternatives, the DeKalb Mental Retardation Council, the Atlanta Alliance on Developmental Disabilities, Annandale Village, and the Marcus Institute.

185 We designed the study carefully to protect the disabled volunteers. First, a consent form was signed by the volunteer and his or her case worker or guardian. The consent form confirmed that the volunteer had discussed participating in the study with someone he trusted and that the participation was voluntary. Second, the volunteer was assigned a nonidentifying number to ensure anonymity. An identification number was composed of the first letter of the first name of the interviewer and a sequential order. For example, the first interviewee by an examiner named Sara would be S1. Sara's next interviewee would be S2. All data was kept using this identification number. Third, after the interview, the volunteer received both a sheet of information explaining the basics of the Miranda rights and an opportunity to ask the interviewer any questions.

186 Grisso collected similar information from his interviewees. The information he collected was: race, sex, socioeconomic status, age, IQ, and prior arrests. Grisso, Juveniles' Waiver of Rights at $212-20$ (cited in note 22). We decided that collecting information regarding an individual's financial status might have little meaning because most people with developmental disabilities qualify for some sort of government assistance, such as Social Security or Medicaid, and many do not have full-time, full-pay jobs. Ideally, we would have obtained information on disability measures such as grade-equivalent reading level and age-equivalent social level. However, since most caseworkers and many guardians and parents lacked this information, our only measure of intelligence was IQ. 
percent experienced mild disability. The remaining 22 percent had IQs from 71 to 88 , which exceeds the IQ of 70 typically used as the upper end for mental retardation. Whenever we refer to the retarded or disabled people in our sample, we include this group of individuals. We decided to include this latter group within the sample to test the performance of people who fell just outside the standard measures of retardation. One of the surprising results of our study was the poor performance of the sample population whose IQ scores were subaverage, yet exceeded the typical cutoff for mental retardation. Nonetheless, by including nonretarded individuals with subaverage IQ scores within the subject population, our study likely overestimates the capacities of disabled people to understand the Miranda warnings.

\section{FIGURE 1 \\ IQS OF DISABLED SUBJECTS}

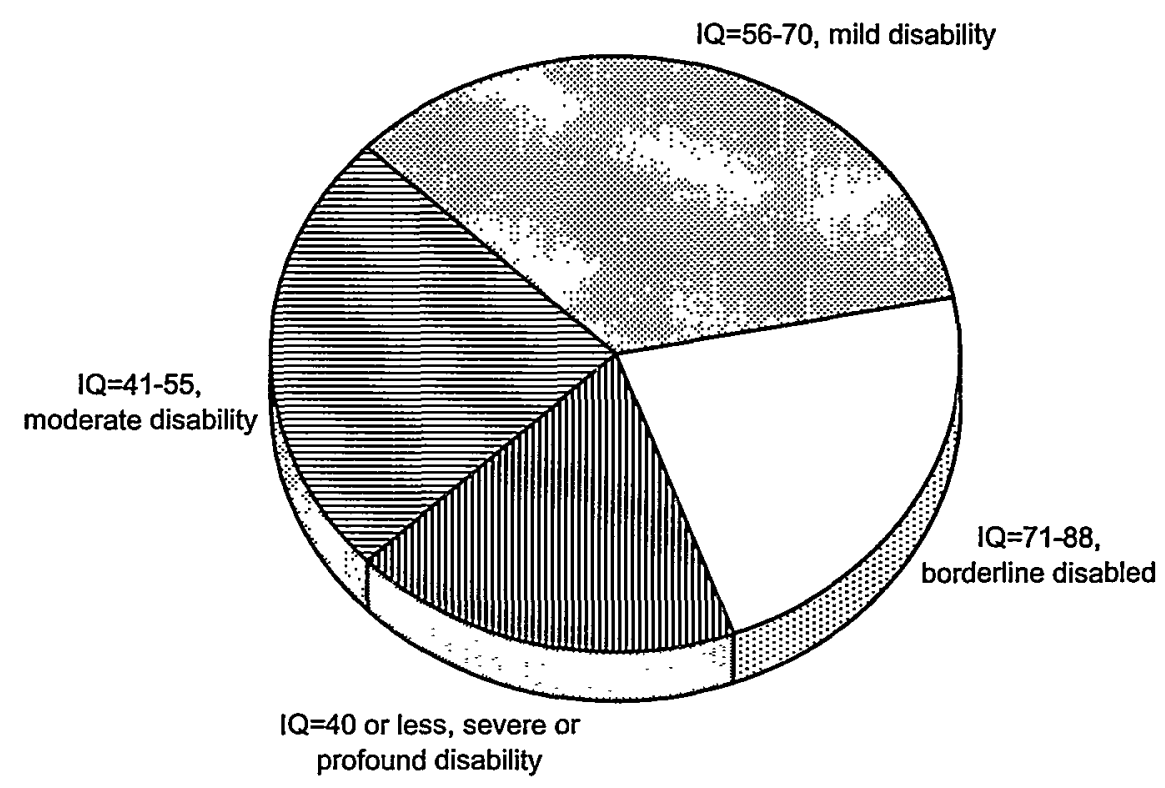

The sample ranged in age from fifteen to sixty-nine with a mean of thirty-seven years. Of the sample, 59 percent were male, and 41 percent female. African-Americans represented 18 percent of the sample. Many of the disabled subjects had completed several years of education, often in special education classes. Approximately one in four of the subjects had had prior contact with the police. Of these, approximately one-third had been read the Miranda rights. ${ }^{187}$

187 See Statistical Appendix, Table 1, for information regarding the disabled subjects' characteristics. 
3. Controls.

In addition, we interviewed twenty-two control subjects. This permitted us to compare the understanding of the Miranda rights exhibited by mentally retarded individuals with the performance of individuals who would be classified as average or above average. In choosing controls, we attempted to get a variety in age, race, gender, education level, contact with police, and socioeconomic level. ${ }^{188} \mathrm{We}$ contacted the controls in several ways, including through the staff of Emory University and through acquaintances of the interviewers.

Apart from IQ, the demographic characteristics of our control subjects were roughly similar to the demographics of our disabled subjects. ${ }^{199}$ The methodology for administering the three tests-the Vocabulary Test, the Warnings Test, and the Concepts Test-to the controls was the same as for the subjects with developmental disabilities. $^{150}$

\section{Grading.}

We sought to ensure standardized grading for the interviews of all mentally retarded subjects and controls, regardless of which interviewer conducted the session. We achieved this in four ways. First, we established stringent grading protocols. ${ }^{191}$ Second, the only interviewers were two of the authors. Third, each interview was tape recorded so the interviewers could carefully check the grading after each interview. Fourth, the two interviewers graded some interviews together and consulted each other when an interviewer could not make a grading decision alone.

188 Our approach to obtaining controls mirrored the approach of the leading study on juveniles' understanding of the warnings. See Grisso, Juveniles' Waiver of Rights at 97-98 (cited in note 22).

189 The controls were, on average, five years younger and had four more years of education. In addition, the control sample had a slightly higher proportion of men and somewhat more African-Americans. A higher proportion of the controls had had earlier police contact-59 percent compared to 27 percent for the disabled. A larger proportion of the controls had also received Miranda warnings before-23 percent compared to 8 percent of the disabled. See Statistical Appendix, Table 2. IQ was not collected from any controls; most people do not know their own IQ and the interviewers were not qualified to administer an IQ test. It is probable that our controls had some diversity in IQ but an average IQ of approximately 100 . See Ellis and Luckasson, 53 Geo Wash L Rev at $427 \mathrm{n} 69$ (cited in note 22) (stating that the mean IQ score is 100).

190 Each control signed a consent form. The control was assigned a nonidentifying number in order to assure anonymity. The interviewer collected information from the control, including his or her age, sex, education level, contact with police, and previous experience with the warnings.

191 See Protocol Appendix. 
B. The Results

The data offer three main results. First, the mentally retarded subjects simply did not understand the Miranda warnings. On each of the three tests, the disabled subjects' scores indicate that, regardless of the level of disability, they did not understand all of the important principles contained in the Miranda warnings. The data show that these mentally retarded subjects possessed insufficient understanding to execute valid waivers of their Miranda rights.

Second, the results raised serious questions about the viability of the totality-of-the-circumstances test commonly used by courts to determine the constitutionality of confessions made by retarded suspects. The data reveal that most of the factors that courts rely upon as indications of the mentally retarded suspect's capacity to understand-age, education, prior experience with the criminal justice system, and prior administration of the Miranda warnings-do not correlate with understanding. Regardless of the presence or absence of these factors, whether taken singly or in combination, if the person was retarded, he did not understand the Miranda warnings.

Third, the results suggest that the Miranda warnings are surprisingly ineffective for many people who are not mentally retarded. Our results indicate that people of average intelligence understand most of their Miranda rights, if somewhat imperfectly. However, many people with below-average IQs, but not low enough to qualify as retarded, do not understand the warnings.

1. They just don't understand.

The mentally retarded subjects understood neither the Miranda warnings nor the rights they describe. As Figure 2's summary of the results shows, those survey subjects who were in our mentally retarded group received low scores on each of the three parts of the test. This was true even though 22 percent of this group had IQs from 71 to 88 , which exceed the standard IQ score of 70 used as the upper range of mental retardation. ${ }^{192}$ In contrast, the control group of nondisabled people did understand the warnings and the rights they describe. The controls achieved high scores on all sections of the test, both in absolute terms and in comparison to the group of retarded subjects.

192 See text accompanying note 67. 
FIGURE 2

GENERAL RESULTS

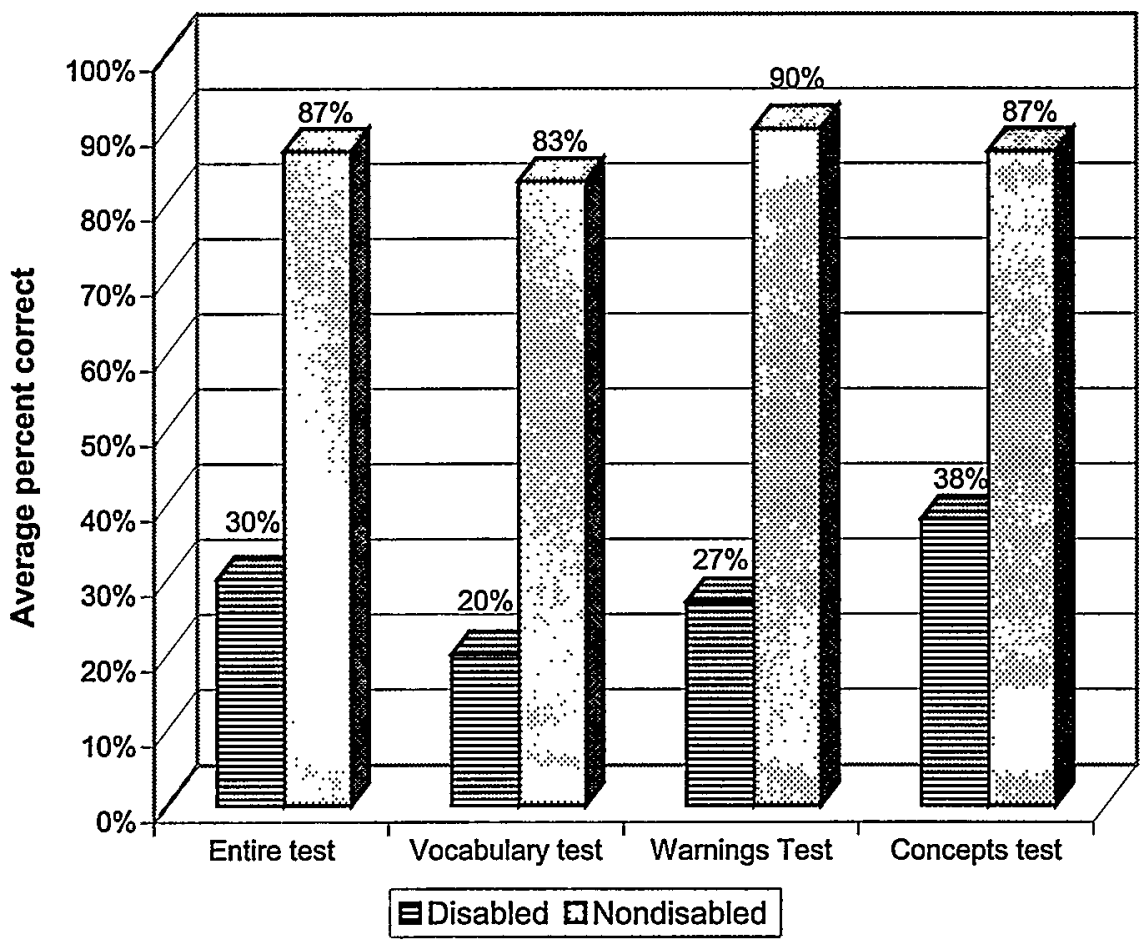

Specifically, our disabled group scored an average of only 20 percent correct on the Vocabulary Test, compared to 83 percent correct for the control group; 27 percent on the Warnings Test, compared to 90 percent for the controls; and 38 percent for the Concepts Test, compared to 87 percent for the controls. Considering all of the tests together, the disabled on average got only 30 percent right, compared to 87 percent for the nondisabled controls.

It is possible to argue that this lack of understanding might not invalidate waivers. The Supreme Court has written that the "Constitution does not require that a criminal suspect know and understand every possible consequence of a waiver of the Fifth Amendment privilege." ${ }^{\text {,193 }}$ The Court made this statement in response to the defendant's claim that a waiver was not knowing and intelligent because law enforcers had not advised him of the full scope of the interrogation. The defendant did not claim that he was incapable of understanding either the words of the warnings or the concepts they embodied.

193 Colorado $v$ Spring, 479 US 564, 574 (1987). For additional discussion of this issue, see notes $275-77$ and accompanying text. 
The results of our study suggest that just the opposite is true of mentally retarded individuals. They understand neither the "basic privilege guaranteed by the Fifth Amendment" nor "the consequences of speaking freely" to police officers. Even the loosest interpretation of the words "knowing" and "intelligent" cannot encompass this level of comprehension.

\section{Results of the Vocabulary Test.}

The group of retarded subjects exhibited poor understanding of the vocabulary used in the warnings. For retarded people, the Miranda warnings, are meaningless because this population does not understand the words used to construct the warnings. As Figure 3 indicates, of the fourteen possible correct points on the vocabulary test, on average, the sample of mentally retarded people and nonretarded people with below-average IQs got correct answers for only approximately one-fifth of the words. ${ }^{194}$ In contrast, the average control subject got more than four-fifths of the total points correct."

194 See also Statistical Appendix, Table 3.

195 Few disabled subjects earned high scores. Most earned low scores. Almost 40 percent of the disabled subjects scored zero total points. That is, they scored no points on all seven of the vocabulary words. High fractions of the disabled subjects received other very low scores. For example, more than 60 percent received two or fewer points out of fourteen; the median score was two. None received a perfect score of fourteen. Only seven of forty-nine disabled subjects earned more than half of the possible points. See Statistical Appendix, Table 3. 


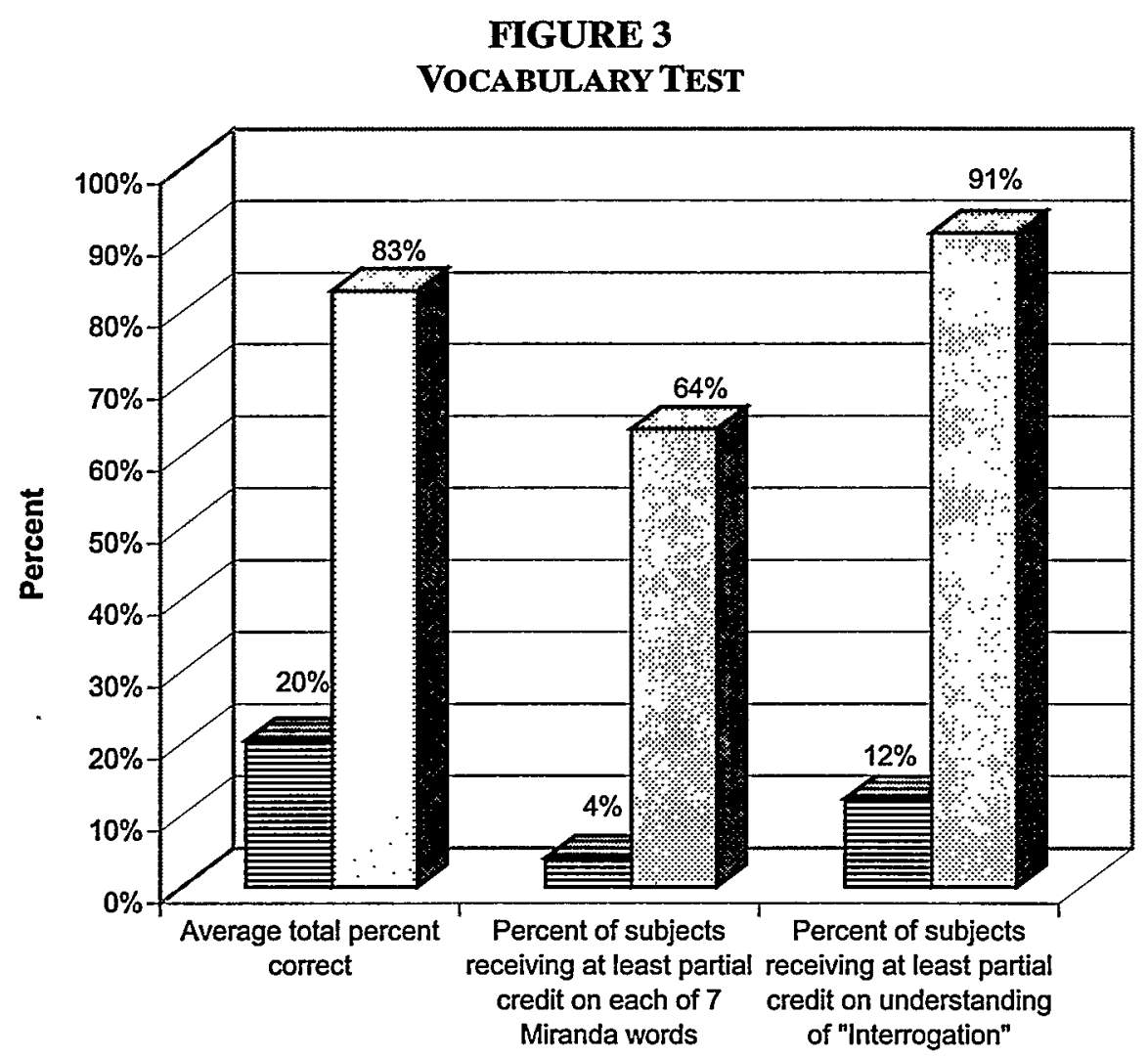

日Disabled Nondisabled

If the constitutional standard of waiver actually means that an individual can only complete a "knowing and intelligent" waiver if he understands the meaning of the Miranda warnings' words, these data suggest that mentally retarded suspects are incapable of meeting this standard. Looking again at Figure 3, only two of the forty-nine retarded subjects, or 4 percent, received even partial credit for each of the seven words. In other words, 96 percent of the mentally retarded subjects received scores of zero understanding on at least one of the seven vocabulary words from the Miranda warnings. In contrast, 64 percent of the nondisabled controls had perfect scores or partial credit on all of the vocabulary words, a percentage sixteen times higher than the retarded subjects achieved.

196 More than three-fourths of the control subjects scored eleven points or higher. No control received fewer than six points. Despite the controls' much better performance relative to the disabled subjects, it is noteworthy that 36 percent of the controls lacked adequate understanding of at least one of the Miranda words. This suggests that the yocabulary of the warning is not perfect even for many nondisabled people. See Statistical Appendix, Table 3. 
Although the disabled subjects' understanding of all of the words was poor, understanding was worse for some words than for others. The most poorly understood word was "interrogation": Figure 3 shows that 88 percent of the disabled completely lacked understanding of this word. The disabled subjects' understanding of the other words also was poor. ${ }^{197}$ In general, for a given word, about three-fourths of the mentally retarded subjects received scores of zero. The scores for the nondisabled controls were markedly superior. For example, in Figure 3 we can see that 91 percent of the controls understood "interrogation" at least partially. In general, on each word, 10 percent or fewer of the controls received scores of zero. ${ }^{198}$

\section{Results of the Warnings Test.}

The results for the first part of the Warnings Test confirm the disabled subjects' fundamental lack of understanding of their Miranda rights. Figure 4 shows that the retarded subjects on average got only 27 percent of the twenty-four items correct, compared to 90 percent for the controls. ${ }^{199}$ As noted earlier, the Warnings Test actually consisted of two sets of items: twelve "comparisons" (in which the subjects were asked to compare two sentences and decide whether they had the same or different meanings), and twelve "yes/no" questions about the meaning of the sentences.

On average, the mentally retarded subjects got correct scores on only 11 percent of the sentence comparisons, compared to the controls, who got 87 percent. The retarded subjects obtained a much higher average score of 43 percent on the yes/no questions, although this still fell far below the average score of 92 percent for the controls. The latter results could indicate a better performance on the "yes/no" portion of the test by the retarded suspects. However, it is likely that these seemingly higher scores result instead from differences in the grading protocols used for the comparison and the yes/no questions.

197 See id.

198 Id.

199 See also Statistical Appendix, Table 4. As with the vocabulary test, most of the disabled subjects received low scores of five or six correct out of twenty-four possible points, and almost no subject received a high score. In contrast, the distribution for the controls was the opposite: most of the controls received high or perfect scores, with none receiving a score below eleven of twenty-four. Id. 
FIGURE 4

WARNINGS TEST, OVERALL RESULTS

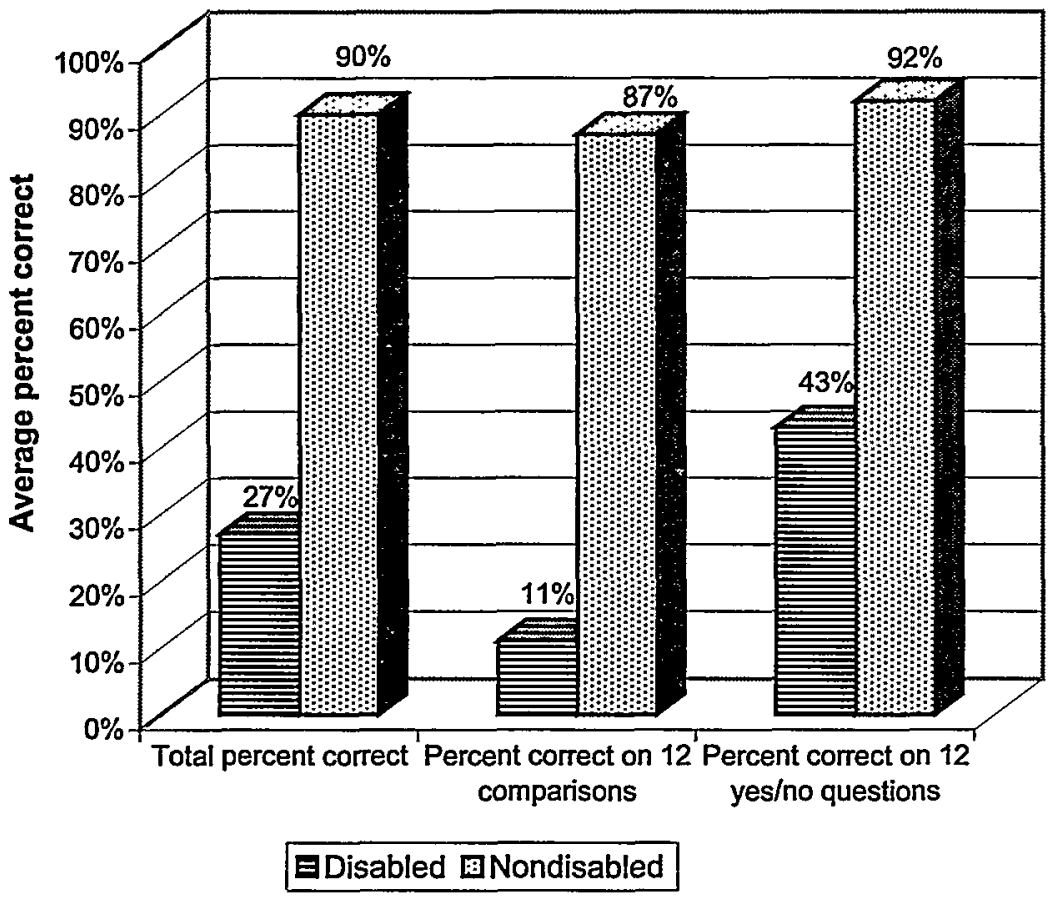

Indeed, the disabled subjects' score of 43 percent on the yes/no questions suggests that the disabled are actively confused about their Miranda rights, rather than simply lacking understanding. Random guessing on the Warnings Test's twelve yes-no questions would have yielded a correct percentage of approximately 50 percent-as opposed to the twelve comparisons, where the testing protocol prevented guessing. ${ }^{20}$ The disabled subjects' 43 percent correct was far worse, and statistically significantly so, than guessing would have achieved..$^{201}$ That the disabled obtained 43 percent correct on the yes/no questions does not indicate that they understood 43 percent of the concepts. Instead, the 43 percent correct indicates abysmal performance in which the disabled performed worse than if, on each question, they had flipped a coin. The disabled systematically choose wrong answers, rather than simply guessing wrong randomly. The disabled's condition leads them to believe mistakenly that they understand the world's workings and their rights within it. The

200 Subjects with inadequate performance on two preliminary sample comparisons were not permitted even to attempt the test's twelve comparisons, receiving all zeros.

201 The disabled's 43 percent correct was statistically significantly less than guessing's 50 percent at a 99 percent confidence level. 
disabled are not clueless. They have strong beliefs that are wrong. The disabled appear to choose the wrong answer with confidence.

The disabled's condition of groundless confidence is especially dangerous in contacts with law enforcement. For example, a person's mere lack of understanding. would create at least uncertainty about whether the person should speak to police. In contrast, a disabled person's certain belief that he must speak creates severe danger that he will quickly and perhaps falsely confess.

The general results achieved by the retarded subjects on the Warnings Test for each of the four sentences of the Miranda warnings indicate that they do not understand any of these sentences. Their misunderstanding was most obvious for the sentences announcing the right to remain silent, the right to a free appointed attorney, and the fact that their statements might be used against them. Their understanding of their right to counsel was still poor, but slightly better, at least in comparison with the other rights. In contrast, the control subjects performed well on each sentence. This is clear from a more careful analysis of the data.

a) Right to silence. The inability of the mentally retarded to understand the Miranda warnings is demonstrated starkly by their inability to understand one of the Miranda fundamental teachings: that the suspect is not required to speak with the police. As Figure 5 shows, the disabled understood their right to silence especially poorly. ${ }^{202}$ For all portions of the test, they scored an average of only 22 percent correct, compared to 87 percent for the controls. Their confusion is emphasized by their performance on the portion of the test requiring them to compare two sentences. 


\section{FIGURE 5}

WARNINGs TEST, RESULTS FOR FIRST MIRANDA SENTENCE: "You Do NOT HAVE TO MAKE A STATEMENT AND HAVE THE RIGHT TO REMAIN SILENT."
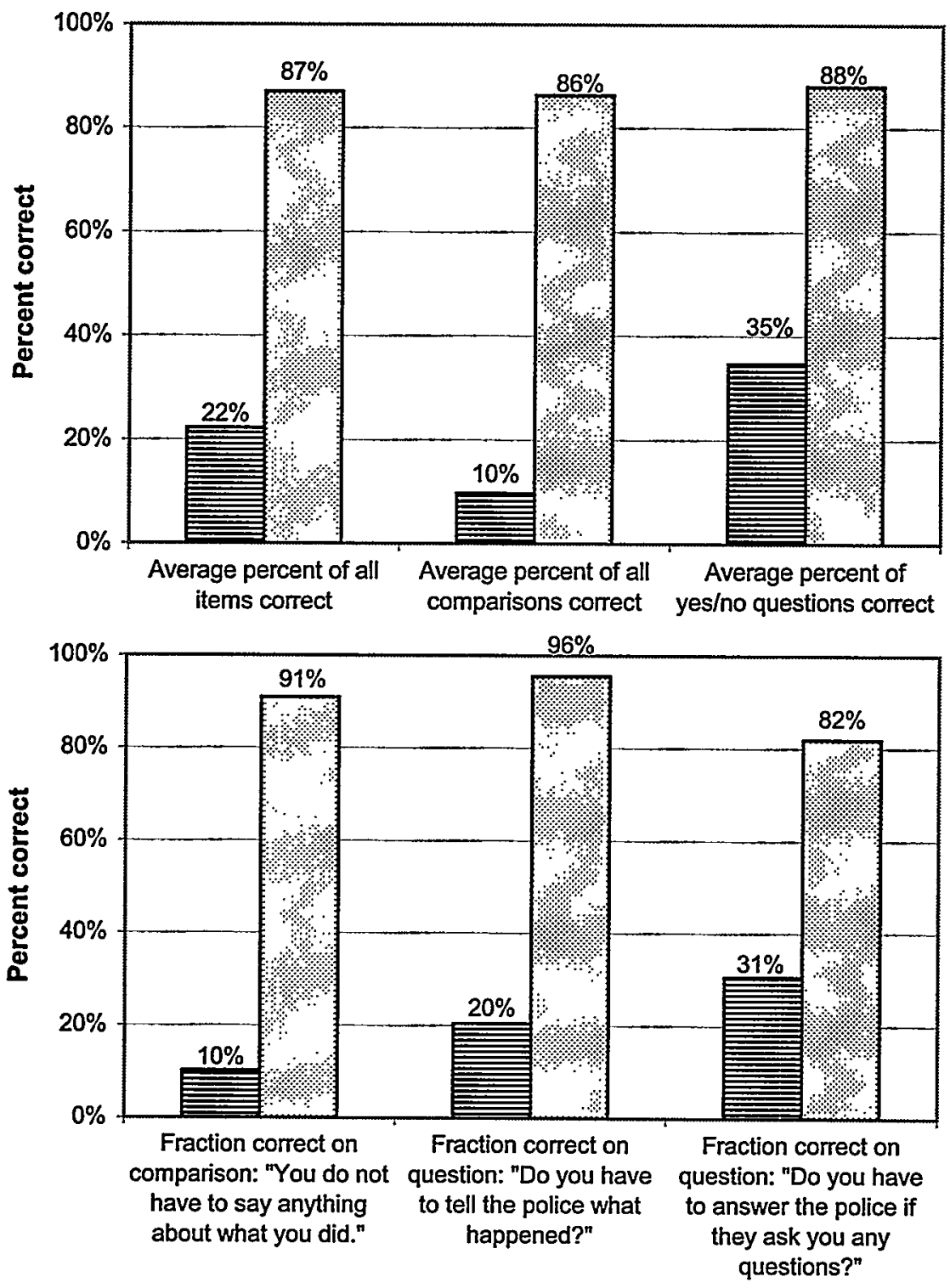

EDisabled $\mathbf{m}$ Nondisabled

As with the other three Miranda sentences, the disabled achieved very low scores on the right-to-silence comparisons. On average, they got only 10 percent of the comparisons correct. Their median number of comparisons correct was zero. In contrast, the controls were correct 
on 86 percent of the comparisons. Similarly, the mentally retarded subjects' overall average number correct of 35 percent on the yes-no questions indicates that the disabled actively misunderstood their right to silence. Again, random guesses should have produced correct answers for about 50 percent of the responses. ${ }^{203}$ In contrast, the nondisabled control group achieved the correct answer 86 percent of the time.

The performance by the mentally retarded subjects on the individual testing items for the right-to-silence sentence reveals the nature and depth of their confusion. For example, after reading each research subject a sentence explaining the right to silence ("You do not have to make a statement and have the right to remain silent"), we asked the subject whether the following sentence had the same or a different meaning: "You do not have to say anything about what you did."

Figure 5 shows that when asked to compare these two sentences, the control group gave the correct answer 91 percent of the time. In stark contrast, the retarded subjects were correct only 10 percent of the time. Similarly, only 20 percent of the disabled subjects answered correctly the question, "Do you have to tell the police what happened?" compared to 96 percent of the controls. Random guessing would have yielded 50 percent correct. Only 31 percent of the disabled gave correct answers when asked, "Do you have to answer the police if they ask you any questions?" far lower than the 50 percent from random guessing and the 82 percent correct score obtained by the control group. ${ }^{24}$

One plausible interpretation of these data is that the mentally retarded subjects simply did not understand the sentences with which they were confronted. The psychological characteristics often exhibited by mentally retarded people discussed above ${ }^{205}$ suggest another possibility. Of particular relevance is the tendency of many retarded people to try to comply with requests from authority figures. It is possible that their poor results on this section of the test result in part from the belief that if police officers asked them a question, they had a duty to respond. If this is correct, it means that the brief Miranda warnings are insufficient to overcome a lifetime of training to comply with requests from authority figures that is amplified by the psychological propensities to comply exhibited by many mentally retarded people. Additional research beyond the scope of the present

203 The disabled subjects' 35 percent is statistically significantly different from 50 percent at a 99 percent confidence level.

204 Again, the disabled's scores were statistically significantly lower than 50 percent at a 99 percent confidence level.

205 See Part III.B. 
study would be necessary to try to identify the cause of this poor performance. Whatever the cause or causes, the performance by the retarded subjects stands in sharp contrast to the control group, who understood that they could refuse to speak with the police.

b) Statements used against suspect. Similar results were obtained for the other three sentences of the Miranda warnings. For example, when answering questions based upon the statement that "[a]nything you say can and will be used against you in a court of law," the mentally retarded suspects got only 31 percent correct, compared to 95 percent for the controls. ${ }^{206}$ Figure 6 reveals that once again, they did abysmally when presented with comparisons, getting only 10 percent correct on average, with a median score of zero, compared to 92 percent correct for the control group. 
FIGURE 6

WARNINGS TEST, $\mathbb{R E S U L T S}$ FOR SECOND MIRANDA SENTENCE: "ANYTHING YOU SAY CAN AND WILl BE USED AGAINST You IN A COURT OF LAW"
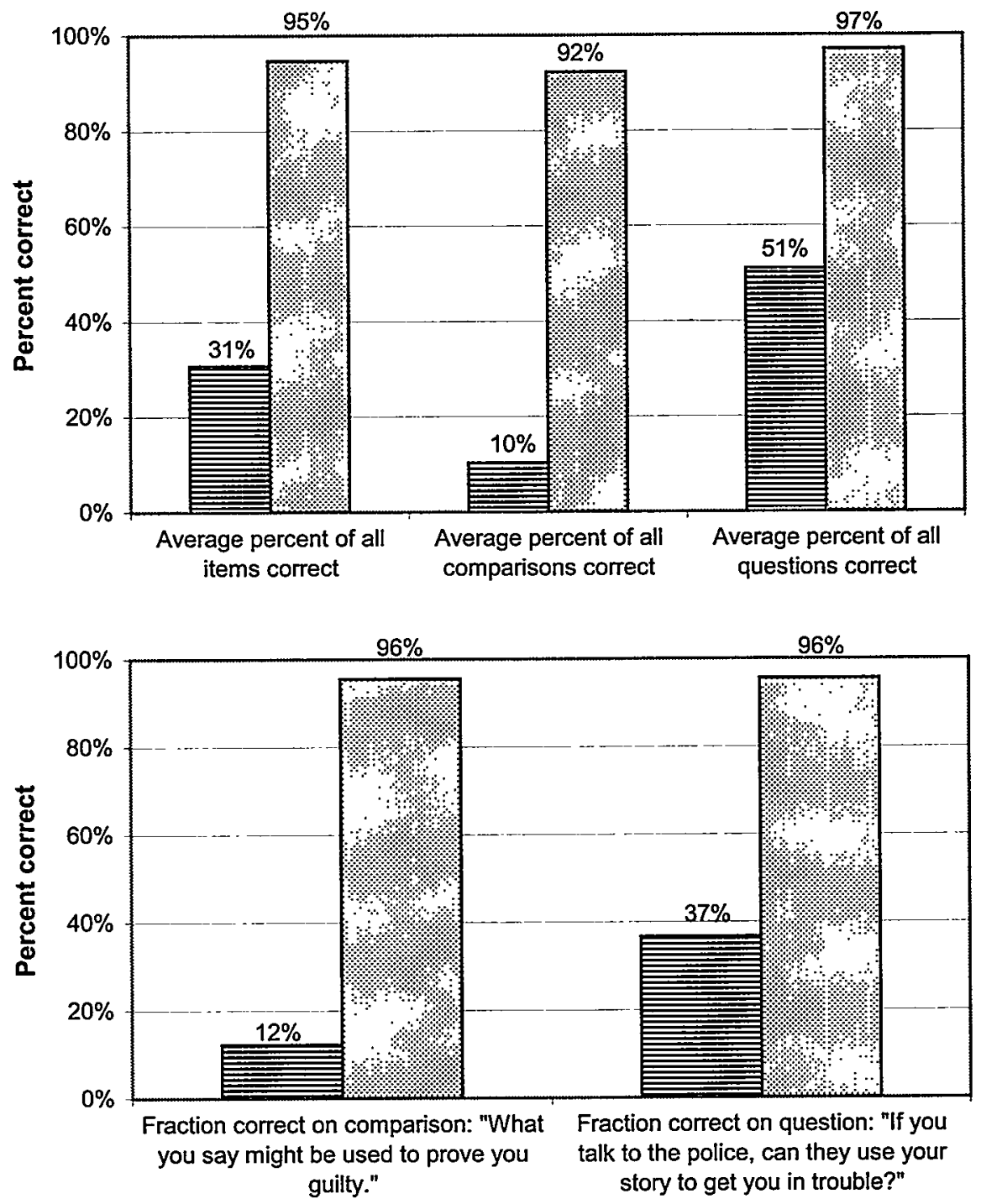

目Disabled QNondisabled

When answering the yes/no questions for this sentence, the mentally retarded subjects got a much higher score-51 percent correct-which is what random guessing should have generated. In contrast, the control group scored 97 percent. 
Yet again, examination of the individual questions highlights the confusion experienced by the mentally retarded subjects. For example, one yes/no question, "If you talk to the police, can they use your story to get you in trouble?" probed understanding of the central lesson of this Miranda sentence. Only 37 percent of the disabled subjects got the correct answer, statistically significantly lower than 50 percent. In contrast, the fraction of the controls with the correct answer was 96 percent. Again it appears that either the psychological characteristics or background and training, or some combination of the two, leads mentally retarded people to score worse than random guessing would produce on this question. ${ }^{20}$

c) Right to consult an attorney. While still large, the gap between the scores earned by the mentally retarded and nondisabled subjects was smaller for questions about the third sentence, "You are entitled to consult with an attorney before interrogation and to have an attorney present at the time of the interrogation." The results are presented in Figure $7 .^{2 \pi}$ The mentally retarded group achieved an average total score of 31 percent, while the control group's average score was 86 percent. While closer than the scores for the previous questions, the retarded subjects answered less than one-third of the questions correctly, and their nondisabled counterparts were nearly three times more likely to get the correct answer.

207 This analysis is supported by another result: only 12 percent of the retarded subjects responded correctly to the comparison question, "What you say might be used to prove you guilty," compared to 96 percent of the control group.

208 See also Statistical Appendix, Table 7. 
FHGURE 7

WARNINGS TEST, RESULTS FOR THIRD MIRANDA SENTENCE: "YOU ARE ENTTLLED TO CONSULT WITH AN ATTORNEY BEFORE INTERROGATION AND TO HAVE AN ATTORNEY PRESENT AT THE TIME OF THE INTERROGATION"
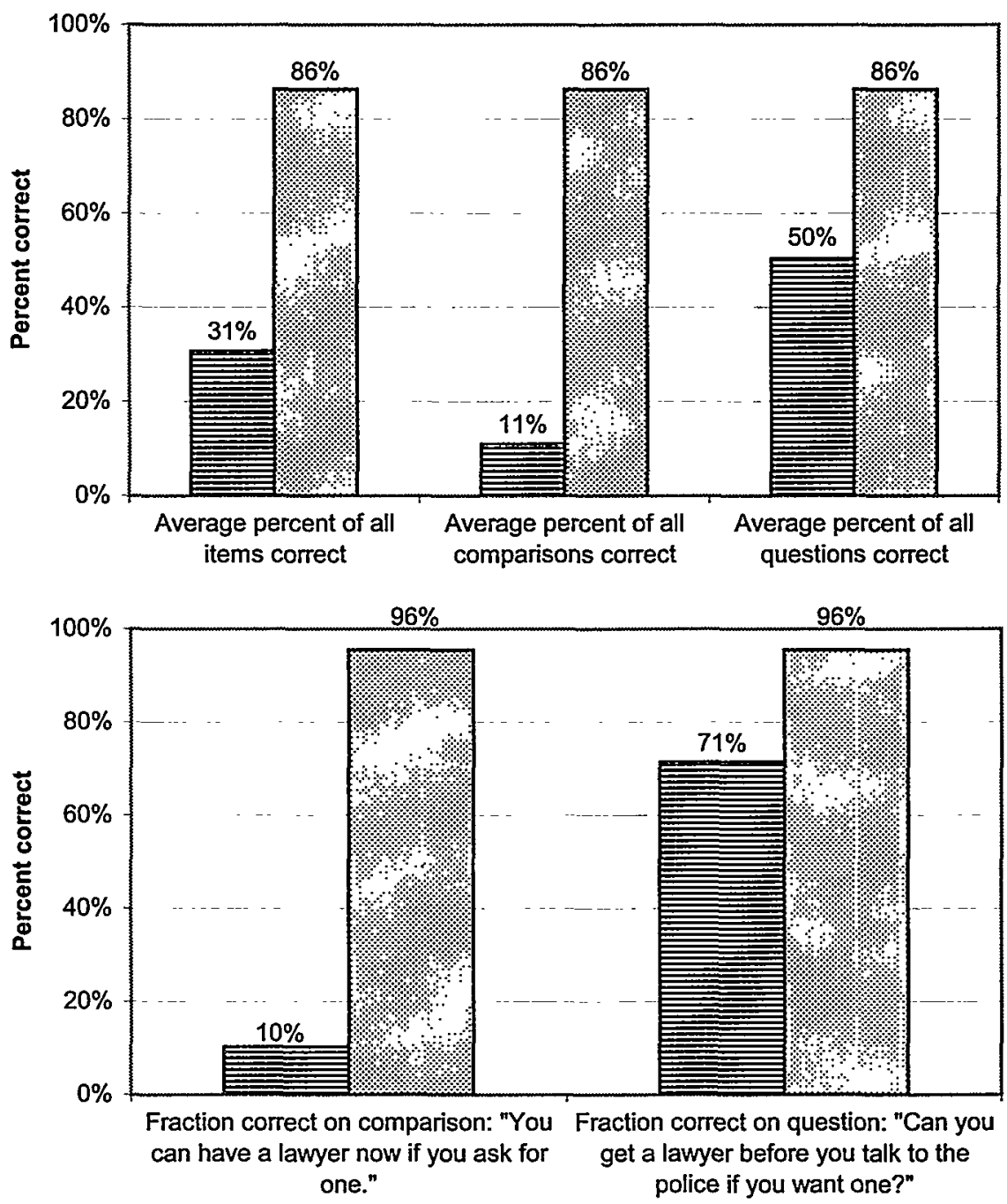

\section{EDisabled Rondisabled}

As with the earlier items seeking comparisons between sentences, the average score for the retarded subjects was extremely low and comparable to the results for the first two sentences. Only 11 percent of the comparisons for the sentence were accurate, and the median correct result was zero. Once again, these data suggest a lack of comprehension of the sentence itself. In contrast, the controls 
averaged 86 percent correct. Again, the results for individual comparisons are enlightening. Only 10 percent of the disabled subjects answered correctly that "You can have a lawyer now if you ask for one" meant the same as the analogous sentence in the Miranda warnings. Nearly all of the nondisabled control group ( 96 percent) got the right answer for this comparison. Likewise, the retarded subjects' average score of 50 percent on the yes/no questions was no better than random guessing. The controls did much better at 86 percent.

This section produced one noteworthy deviation from the typical pattern of scores achieved by the mentally retarded group. When asked the "yes/no" question, "Can you get a lawyer before you talk to the police if you want one?" 71 percent of the disabled answered correctly. This is much closer than usual to the control group's score of 96 percent. The result is anomalous, because the subjects' very low scores on the comparison questions indicate that they did not comprehend the sentence as contained in the Miranda warnings. Yet their performance on this related yes/no question suggests that the group generally comprehends that they have the right to obtain an attorney. One possibility is that they learned this in some other setting and at an earlier time. One must wonder, however, why the subjects would have previously learned they had the right to an attorney, but not that they had the right to remain silent.

d) Right to appointed attorney. The result on the previous yes/no question is even more anomalous when compared to the results obtained for the fourth sentence from the Miranda warnings, "If you cannot afford an attorney, one will be appointed for you." As Figure 8 shows, the disabled subjects answered only 25 percent of the items correctly, barely more than a quarter of the control group's 90 percent correct result. $^{209}$ In particular, the retarded subjects again scored particularly poorly on the sentence comparisons, answering only 15 percent of the items correctly, and achieving a median of zero. 
FIGURE 8

WARNINGS TEST, RESULTS FOR FOURTH MIRANDA SENTENCE: "If YOU CANNOT AFFORd AN ATTORNEY, ONE WILL BE APPOINTED FOR YOU"
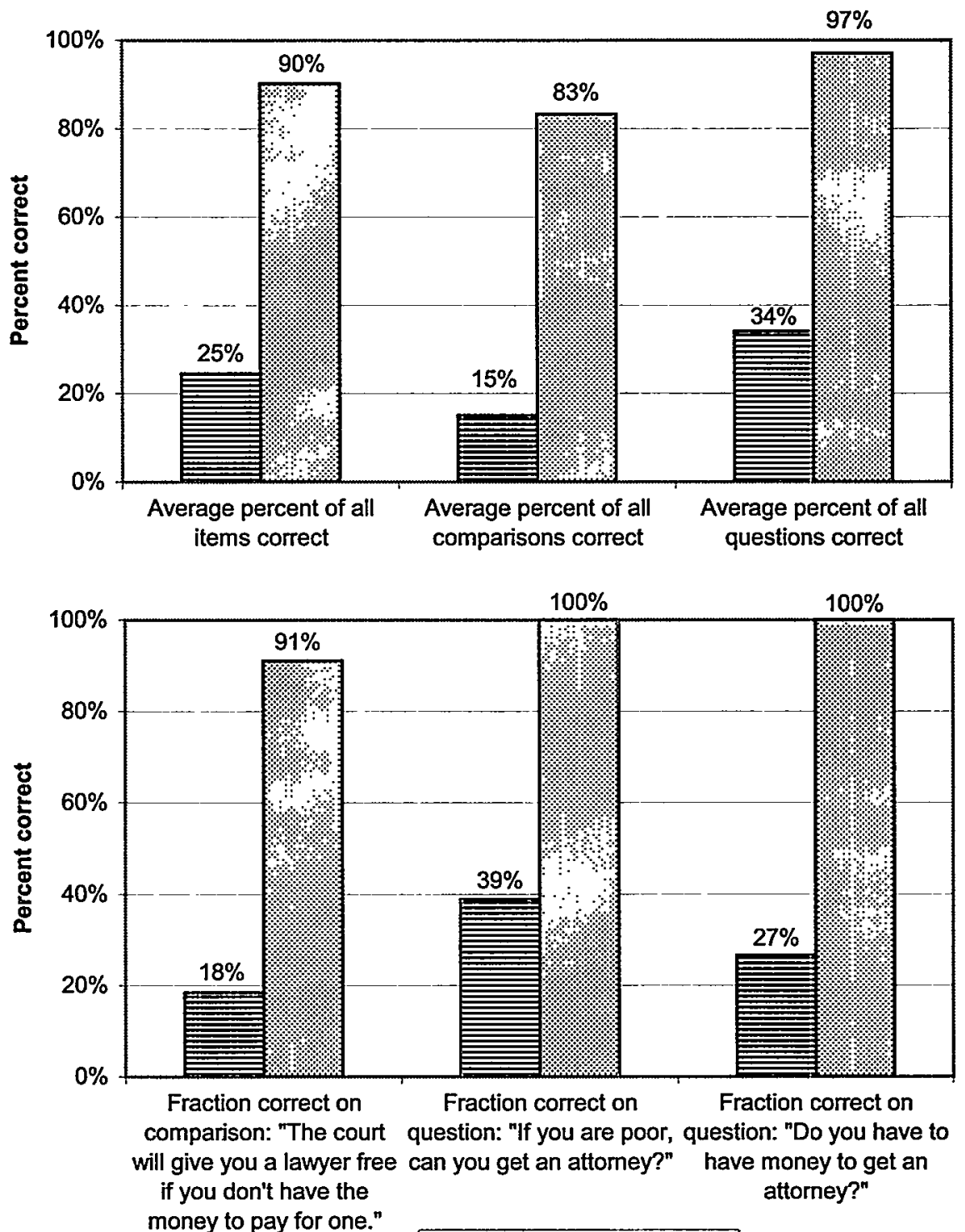

目Disabed $\mathbf{0}$ Nondisabled

Their performance on the yes/no questions suggests that the disabled actively misunderstand their right to an attorney. The average disabled subject got only 34 percent correct, far worse than the expected outcome from random guessing. In contrast, the controls got an average of 97 percent correct. The palpable gap between the scores 
for the two groups is emphasized by examining the responses to specific yes/no questions. For example, when asked "If you are poor, can you get an attorney?" and "Do you have to have money to get an attorney?" the nondisabled controls scored 100 percent correct on both questions. Only 39 percent and 27 percent of the disabled subjects correctly answered the two questions, respectively. The results suggest that the disabled actively believe that attorneys are available only to people with money. The Miranda sentence's contrary pronouncement was not sufficient to change this belief.

4. Results for the Concepts Test.

The results for the Concepts Test indicate that the disabled subjects' understanding of the legal context within which Miranda rights might be exercised is both inconsistent and poor. Figure 9 provides the overall results as well as the results for the three subsections of the test. In the Concepts Test as a whole, the disabled got only 38 percent of the possible points, compared to 87 percent for the controls. These results suggest that even if retarded suspects could understand the Miranda rights, they would lack sufficient understanding of the legal context in which they had become enmeshed to be able to waive their rights knowingly and intelligently. 
FIGURE 9

CONCEPTS TEST, OVERALL RESULTS

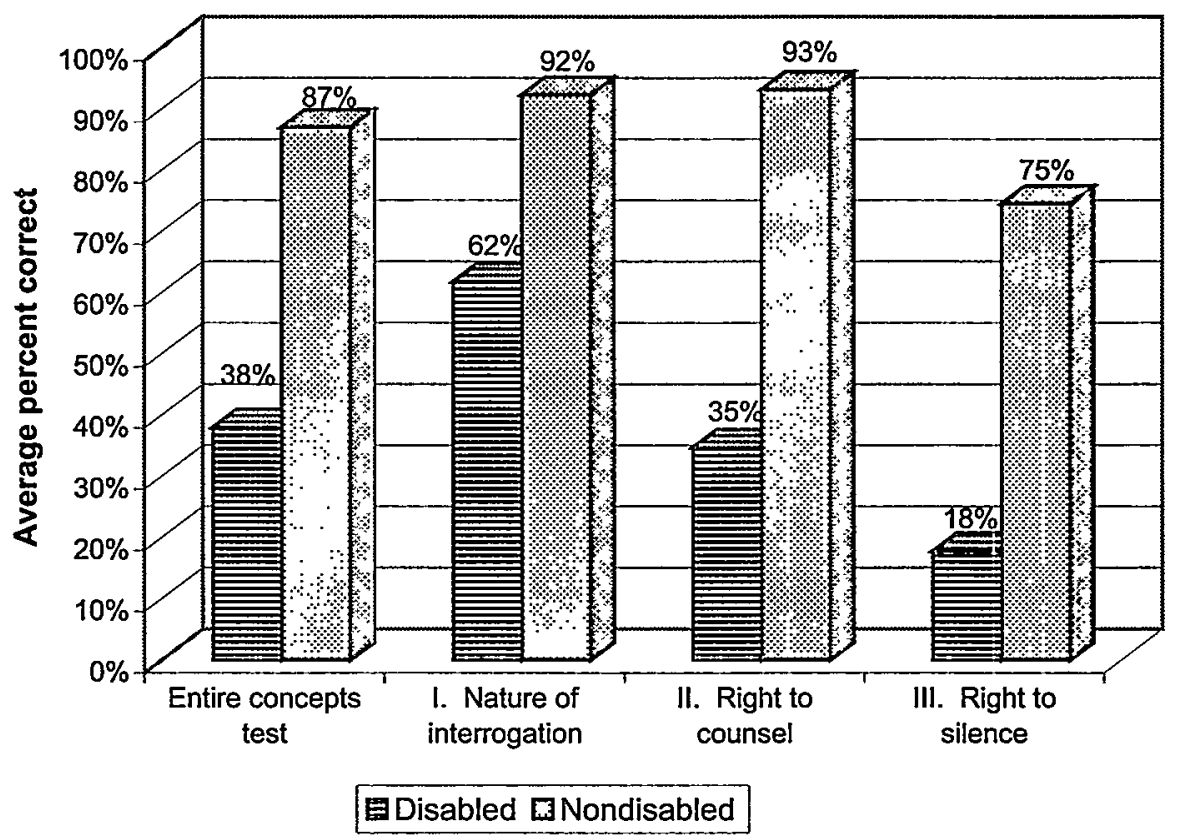

The results for the three subsections reinforce this conclusion. The disabled's understanding of the nature of interrogation is low, although higher than their understanding in other areas of the test. The disabled subjects' understanding of the questions concerning the right to counsel was much lower, and their understanding of the right to silence in the context of the criminal justice system was minimal. Although the members of the disabled group displayed some understanding of the workings of an interrogation, they were unable to understand more complex concepts such as the roles of client and lawyer and the nature and ramifications of the decision to invoke the right to silence.

a) Nature of interrogation. We begin with the first subject: the nature of interrogation. As Figure 9 reveals, the mentally retarded group scored 62 percent correct on this section. While higher than the results achieved by this group on almost all other parts of the test, it still fell far short of the average correct score of 92 percent for the controls. Nonetheless, it appears that either the disabled subjects' education and life experience, or the administration of the warnings, or some combination of the two, gave them at least some understanding of an interrogation's purpose and protocol.

It is worth noting that even with the disabled subjects' higher average score for this entire section of the test, the scores on some 
significant subparts of the section on the nature of interrogation were lower. As illustrated in Figure 10, for example, it appears that the disabled subjects' understanding of the implications of a decision to waive Miranda rights was less than their overall understanding of the nature of interrogation. ${ }^{210}$ A relatively small number fully understood the officers' objectives in the interrogation and the information that they sought. On both of the questions that explored these issues, fewer than 50 percent fully understood that, in an interrogation, the officers sought either to obtain the suspect's confession or to learn about the suspect's involvement in, or knowledge of, the crime. In contrast, more than two-thirds of the disabled group understood that in an interrogation the police believe that the suspect may have committed a crime. 
FIGURE 10

CONCEPTS TEST, NATURE OF INTERROGATION, PERCENT OF ADEQUATE (2-POINT) RESPONSES ON ITEMS
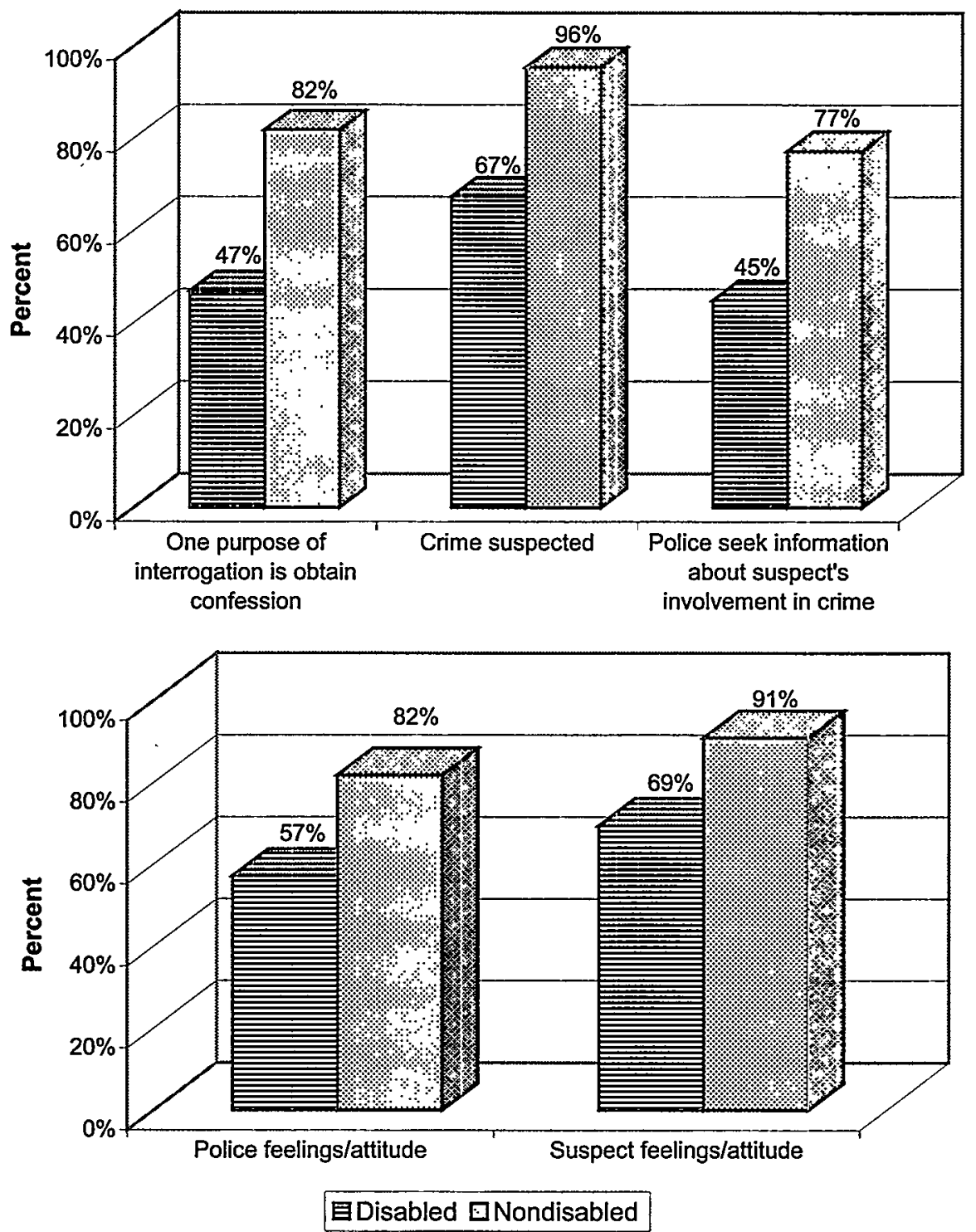

b) Right to counsel. The disabled subjects' performance on the section of the test designed to examine the interviewee's understanding of the lawyer's and client's roles was worse. The results they achieved on the Right to Counsel measure revealed that the mentally retarded do not understand these roles. Returning to Figure 9 , the disabled scored on average only 35 percent correct, compared to 
93 percent for the controls, and compared to the disabled subjects' 62 percent for the section on the Nature of Interrogation.

The responses on the section's subparts, reported in Figure 11, confirm both the disabled's lack of understanding and the profound nature of their confusion. ${ }^{211}$ Most of the disabled do not understand that the lawyer is the suspect's advocate. Instead, the disabled confuse the role of the lawyer with the roles of police, prosecutor, and judge. For example, only 23 percent of the disabled subjects understood fully that the lawyer's role was to work in the interests of the suspect. Instead, 53 percent believed that the lawyer was the suspect's adversary. For example, a common belief among the disabled was that the lawyer's job was either to convince the suspect to confess or to decide whether the suspect was guilty. ${ }^{212}$

211 See also Statistical Appendix, Table 10.

212 For a listing of common responses, see the study's grading protocol, reproduced in the Protocol Appendix. 
FIGURE 11

\section{CONCEPTS TEST, UNDERSTANDING VS. MISUNDERSTANDING OF ASPECTS OF RIGHT TO COUNSEL: DISABLED SUBJECTS}

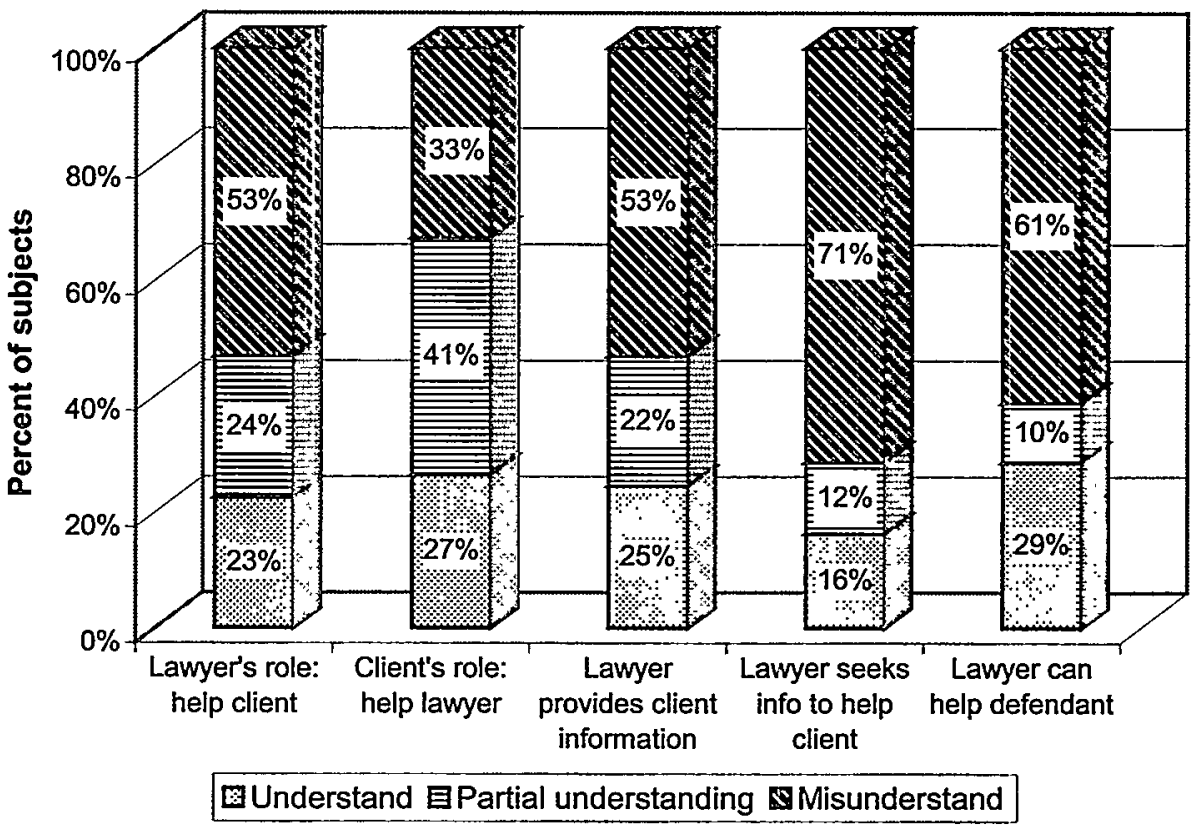

Likewise, only 27 percent of the mentally retarded subjects understood that the client's role with his lawyer was to be helpful and truthful. Instead, many of the disabled felt that, because they believed that the lawyer was an adversary, the suspect's appropriate behavior with the lawyer was to keep quiet and not confess to anything. Similarly, only 25 percent understood that the lawyer would provide helpful information about the interrogation and future court-related processes. Instead, 53 percent believed that the main words from the attorney would be harsh and accusatory: for example, that the suspect was guilty and would have to pay for it, or that the suspect was a failure.

Only 16 percent understood that the lawyer asked the suspect about the facts of the case in order to help defend the suspect. Instead, 71 percent felt that the lawyer asked only in order to determine whether the suspect should be punished. For example, the mentally retarded subjects commonly stated that the lawyer sought information only to tell the judge about it, to decide whether the suspect should go to jail, or to determine whether the suspect should be found guilty. Finally, only 29 percent recognized fully that having a lawyer could 
benefit them in court. Instead, 61 percent believed that having a lawyer would have a negative effect.

The disabled subjects' pervasive confusion about the lawyer contrasted with the control subjects' firm understanding, with high total scores and high scores on each of the section's subparts, as shown in Figure $12 .{ }^{213}$ The controls readily understood the lawyer's role. The disabled did not.

FIGURE 12

CONCEPTS TEST, UNDERSTANDING VS. MISUNDERSTANDING OF ASPECTS OF RIGHT TO COUNSEL: NONDISABLED SUBJECTS

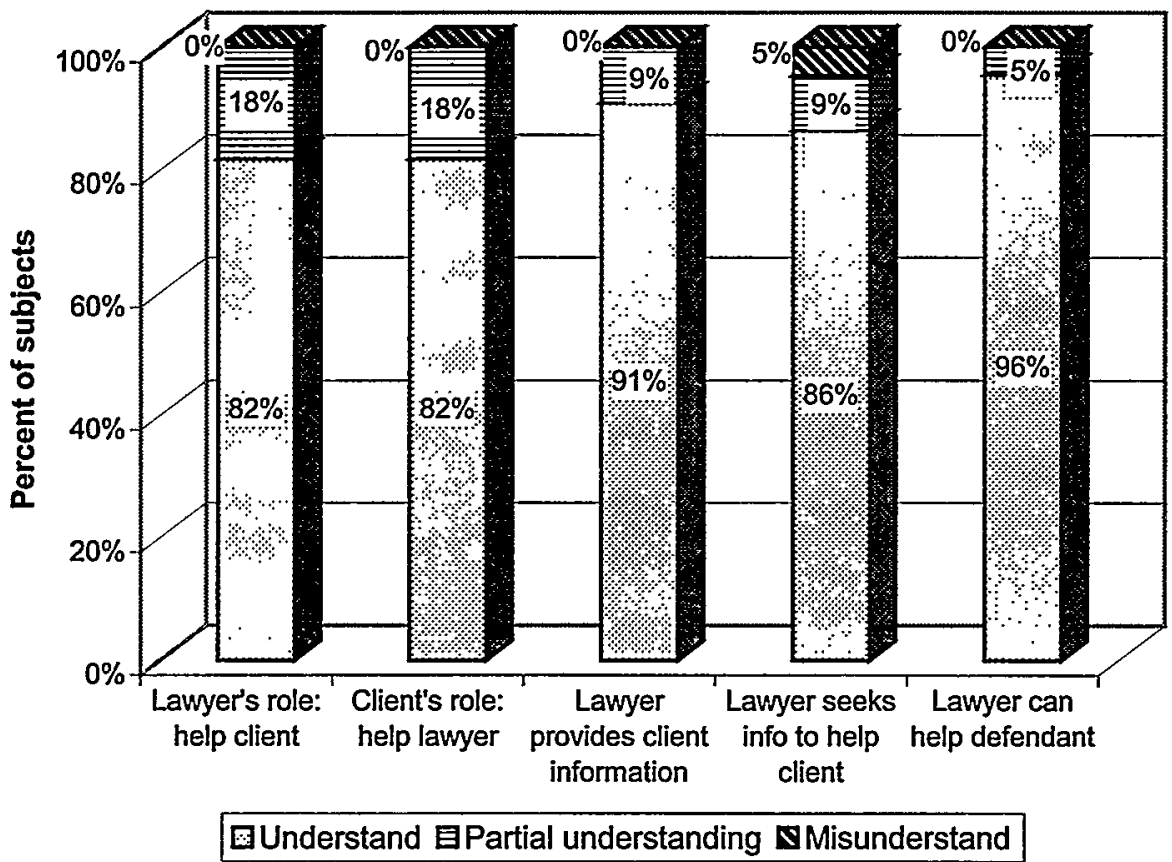

The disabled subjects' confusion about the lawyer's role eviscerates their right to counsel. A suspect who believes that the lawyer will be the suspect's adversary will choose not to request a lawyer.

c) Right to silence. The mentally retarded subjects' understanding of the context of the right to silence was even worse. Although the warnings tell the suspect that he has the right to remain silent, the disabled are deeply confused about what the right to silence means in practice. As Figure 9 shows, on the Right to Silence section, the disabled got only 18 percent right. 
The retarded subjects' responses on the subparts reveal the nature of the confusion. As Figure 13 shows, only 12 percent recognized that the right to silence prohibited the police from forcing the suspect to talk. ${ }^{214}$ Only 18 percent understood that the judge could neither override a suspect's invocation of the right to silence nor compel the suspect to testify.

FIGURE 13

CONCEPTS TEST, UNDERSTANDING VS. MISUNDERSTANDING OF ASPECTS OF Right TO SILENCE: DISABLED SUBJECTS

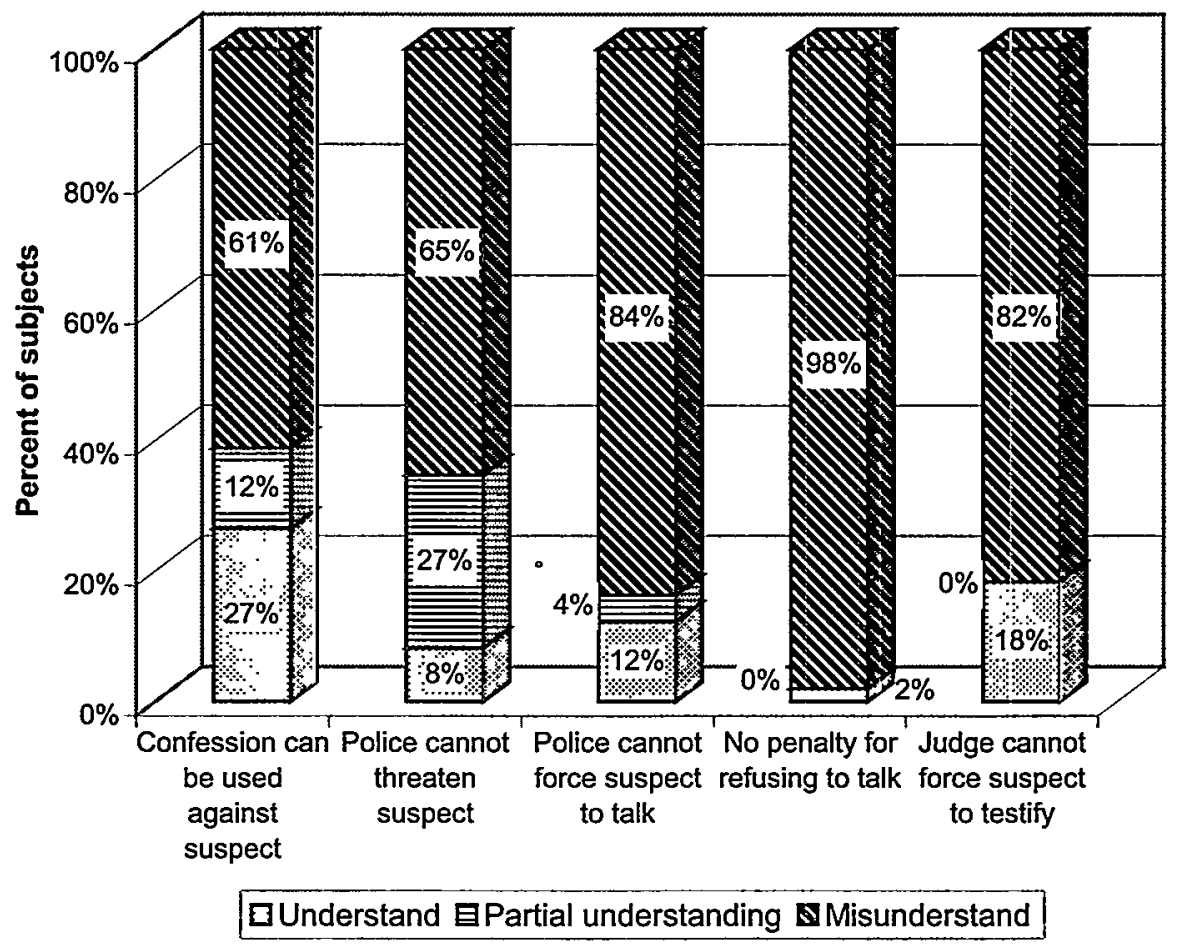

Finally, only 2 percent recognized that the suspect could not be penalized for asserting his right to silence. Instead, 98 percent of the disabled subjects believed that the decision to remain silent would be punished. Common beliefs were that silence would lead the judge to make punishment worse, to think that the suspect was guilty, or to say that if the suspect were not guilty, he should have nothing to hide. ${ }^{215}$

As with the confusion about the right to counsel, the disabled subjects' misunderstandings of the right to silence effectively

214 See also Statistical Appendix, Table 11.

215 See the grading protocol, reproduced in the Protocol Appendix. 
eliminate the right. The misunderstandings could easily cause a disabled person to waive the right and confess. A suspect would have little incentive to remain silent if the suspect believed, as the disabled do, that the police or judge could nonetheless compel the suspect to speak. Likewise, mentally retarded suspects might fear remaining silent because they believe that the judge will punish the silence.

Although the controls understood the right to silence far better than did the disabled subjects, the controls' understanding of this right was substantially worse than their understanding of other Miranda rights. As shown in Figure 9, the controls scored only 75 percent correct, substantially lower than their scores both on other parts of the Concepts Test and on the other tests. Moreover, the controls' scores on the right-to-silence subparts suggest substantial confusion as to various aspects of the right to silence. As Figure 14 shows, 59 percent of the controls thought that the judge could compel a defendant to speak. ${ }^{216}$ Likewise, 27 percent believed that the judge could penalize invocation of the right to silence. Smaller but still substantial numbers of the controls believed that the law permitted the police both to put pressure on a suspect who chose to remain silent and to force the suspect to speak. 
FIGURE 14

\section{CONCEPTS TEST, UNDERSTANDING VS. MISUNDERSTANDING OF} ASPECTS OF RIGHT TO SILENCE: NONDISABLED SUBJECTS

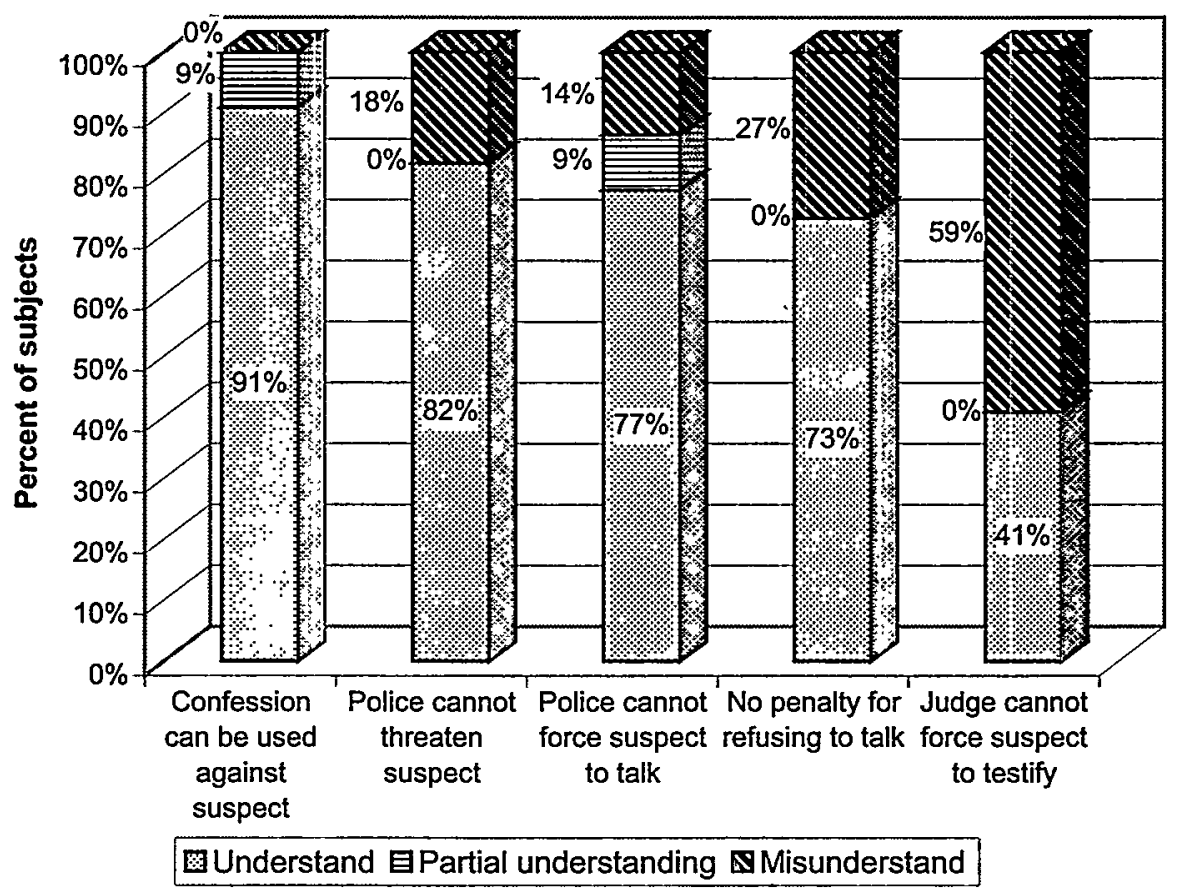

5. The understanding of the controls.

The three tests demonstrate that the control subjects' understanding of the Miranda warnings generally was quite good, but with one major gap and a few minor ones. On the Vocabulary Test, the controls did well overall, obtaining 83 percent of possible points. ${ }^{217}$ However, understanding was not perfect. For three of the words"consult," "right," and "statement"-almost half of the controls did not obtain perfect scores. ${ }^{218}$ For "appoint," 18 percent of the controls received zero points. ${ }^{219}$

The controls' performance on the Warnings Test was also quite good, with average scores of approximately 90 percent for both the comparisons and yes/no questions. ${ }^{20}$ The controls also had a firm understanding of each individual right within the Miranda warnings,

\footnotetext{
217 See Figure 3 and Statistical Appendix, Table 3.

218 Statistical Appendix, Table 3.

219 Id.

220 See Figure 4 and Statistical Appendix, Table 4
} 
as indicated by their sound performance on the Warnings Test's four subsections, including the right to silence. ${ }^{21}$

Likewise, the controls did well on the first two parts of the Concepts Test. They understood well both the nature of interrogation and the context surrounding the right to counsel.

If the Miranda warnings were to be improved in one area, it should be in expressing the right to silence more clearly and completely. The Concept Test's third section on the right to silence shows that the disabled misunderstand the right completely. The controls misperceive it partially, earning only 75 percent of the total points. ${ }^{23}$ Specifically, the results suggest that the warning should express more clearly both that a suspect cannot be punished for asserting the right and that neither the police nor the judge can override the right. $^{24}$

6. Inadequacy of the totality-of-the-circumstances test.

Multivariate regression analysis demonstrates that the courts' totality-of-the-circumstances test for evaluating confessions by mentally retarded suspects is inappropriate and misguided. Our results undermine both of the essential hypotheses that justify the test. First, most of the factors that courts assume can increase understanding do not have that effect. Second, if a subject is disabled, then the subject cannot understand the Miranda warnings, regardless of the presence of any other factors.

a) Three of the courts' five factors do not influence understanding. Regression analysis permits us to reject the courts' first working hypothesis that the following factors all influence a disabled suspect's level of understanding of her Miranda rights: intelligence, measured by IQ; age; level of education; previous contact with police; and previous administration of the Miranda warnings. The stars in Figure 15 indicate which of the courts' variables (plus race and sex) had an impact, ${ }^{25}$ the other factors held constant, on each of four measures of understanding of the Miranda warnings. The four measures of understanding in the regressions were the combined percent correct on all of the tests (in column 1 of Figure 15) and the three individual test scores (in columns 2-4).

221 See Figures 5-8 and Statistical Appendix, Tables 5-8.

222 See Figures 9, 10, and 12 and Statistical Appendix, Tables 9-10.

223 See Figure 9 and Statistical Appendix, Table 11.

224 See Figure 14 and Statistical Appendix, Table 11.

225 "Impact" here means statistically significant at at least a 10 percent confidence level. See Statistical Appendix, Tables 12-17.

226 Figure 15 summarizes the regression results from the Statistical Appendix, Tables 12,13, 14 , and 16. To identify the influences on each measure of understanding, we ran two regressions 
FIGURE 15

REGRESSION RESULTS FOR TOTAL SCORE AND THREE TESTS

\begin{tabular}{|c|c|c|c|c|c|}
\hline & & \multicolumn{4}{|c|}{ Stars indicate significant influences on: } \\
\hline & & Column 1 & Column 2 & Column 3 & Column 4 \\
\hline & & $\begin{array}{l}\text { Percent } \\
\text { correct on } \\
\text { all tests }\end{array}$ & $\begin{array}{c}\text { Score on } \\
\text { Vocabulary } \\
\text { Test }\end{array}$ & $\begin{array}{c}\text { Score on } \\
\text { Warnings } \\
\text { Test }\end{array}$ & $\begin{array}{c}\text { Score on } \\
\text { Concepts } \\
\text { Test } \\
\end{array}$ \\
\hline \multirow{7}{*}{ 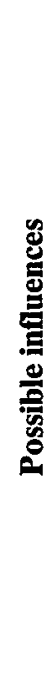 } & $\begin{array}{l}\text { Disabled (IQ below } \\
\text { 90) or IQ }\end{array}$ & & & & \\
\hline & Age & & & & \\
\hline & $\begin{array}{l}\text { Years of education } \\
\text { completed }\end{array}$ & & & & \\
\hline & \begin{tabular}{|l} 
Earlier contact with \\
police
\end{tabular} & & & & \\
\hline & $\begin{array}{l}\text { Earlier Miranda } \\
\text { warning }\end{array}$ & & & & \\
\hline & Race & & & & \\
\hline & Sex & & & & \\
\hline
\end{tabular}

For all four measures of understanding, the only significant influences were disability/IQ and earlier contact with the police. ${ }^{27}$ Indeed, for the score on the Vocabulary Test in column 2, only disability/IQ was a significant influence. ${ }^{23}$ Contrary to the courts' common hypothesis, the other factors that courts often consider-age, years of education, previous Miranda warnings-influenced none of

for each measure. First, we ran the regression with all of the test subjects, both disabled and controls. Because we lacked information on the controls' IQs, we used a dummy variable to indicate whether the subject was in our disabled group. The details of these results appear in the Statistical Appendix, Tables 12-16. Our second regression examined which of the factors influenced the total percent correct among the disabled. That is, the second regression examined whether, among the disabled subjects, there was a significant impact on percent correct from IQ, age, education, contact with police, earlier warnings, race, or sex. Limiting the second regression to the disabled, for whom we had IQ data, permitted us to examine the influence on understanding of the level of each subject's disability, rather than merely whether the subject was disabled, as in the first regression. Because the coefficients that were significant were the same for both sets of regressions, Figure 15 combines the regression results into a single column for each measure.

227 At either the 5 percent or 10 percent significance level.

228 See also Statistical Appendix, Table 13. 
the four measures of understanding. We also tested the possible influence on understanding of the subject's race and sex, although courts do not formally consider these characteristics as part of the totality-of-the-circumstances test. We found that race and sex had no significant influence on understanding. ${ }^{29}$

Not only did being disabled have an impact on understanding, the impact was large. Figure 16 depicts the sizes of the impacts on the four measures of understanding from each of the factors. ${ }^{200}$ All other things equal, the impact of being in the disabled group with an IQ below 88 was to decrease a disabled subject's score by 52 percentage points. That is, a disabled subject who, if not disabled, would have received an overall score of 90 percent correct, would on average instead earn only 38 percent. Similarly, on the Vocabulary Test, all else equal, the disabled subjects received 57 percentage points less than the nondisabled subjects. On the Miranda Warnings Test, they received 58 fewer percentage points. On the Concepts Test, being disabled reduced a subject's score by 40 percentage points.

230 Figure 16 summarizes the sizes of the coefficients in the Statistical Appendix, Tables 12, 13,14 , and 16 . 


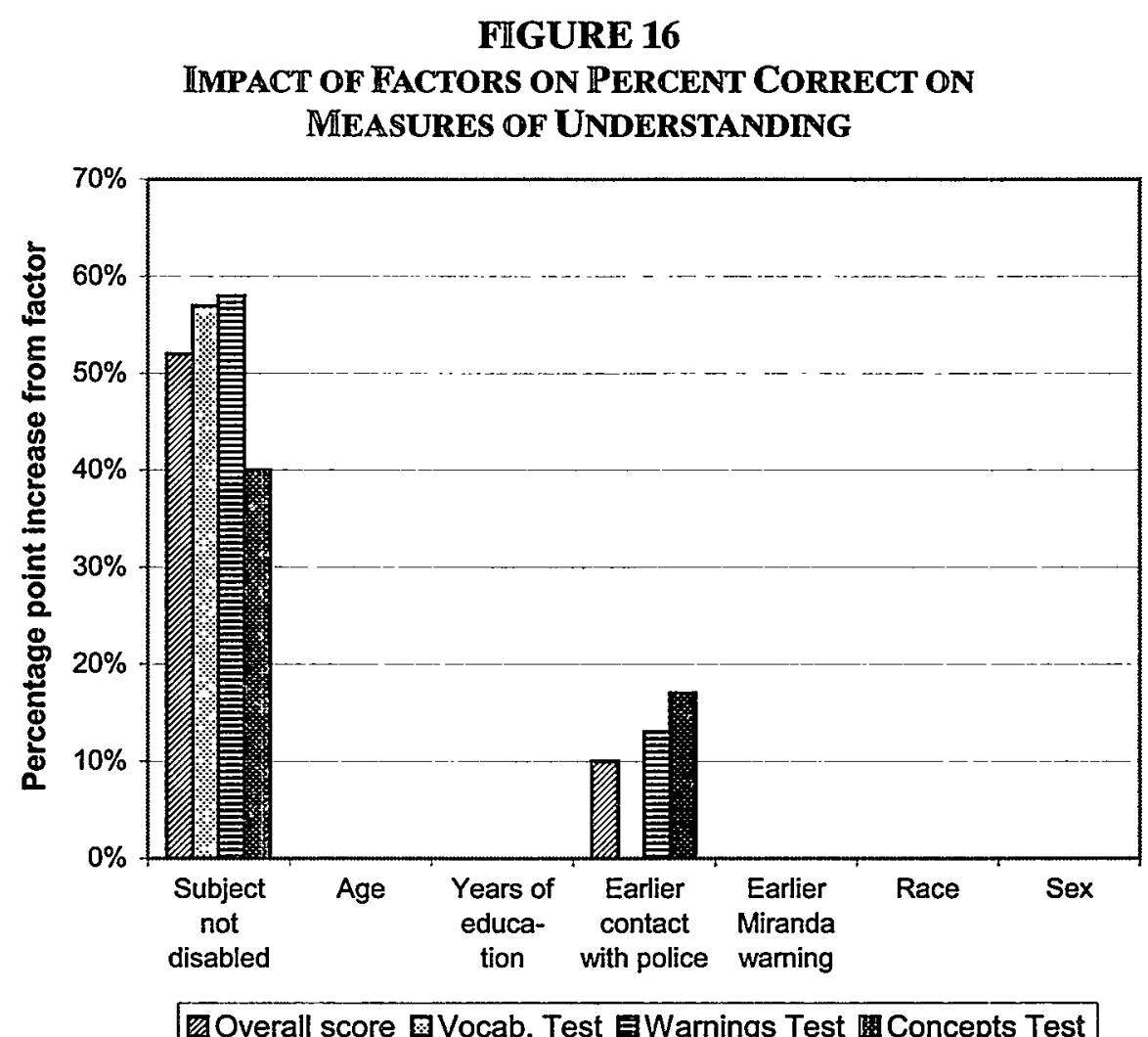

Although earlier police contact had an impact on understanding, its impact was small. All other things equal, subjects with earlier police contact earned 10 percentage points higher overall scores. ${ }^{231}$ Police contact had no significant impact on scoring on the Vocabulary Test. It increased scoring by only 11 percentage points on the Warnings Test and only 17 percentage points on the Concepts Test. ${ }^{22}$ As we saw already in Figure 15 and as we see again in Figure 16, all of the other factors had no significant impact. ${ }^{233}$

b) A disabled subject fails to understand the warning, regardless of other factors. Regression analysis also rejects the courts' second working hypothesis: that a defendant with high levels of the other factors will understand his Miranda rights, even if his low IQ indicates

231 See Statistical Appendix. This is the result for the regressions that included all subjects. In the regression that included only disabled subjects, the impact of prior police contact was a slightly higher 12 percent. Id.

232 Statistical Appendix, Tables 14 and 16. The regressions with only disabled subjects yielded similar results: impacts of 10 percent for the Warnings Test and 20 percent for the Concepts Test. Id.

233 See also Statistical Appendix, Tables 12, 13, 14, and 16. 
mental retardation. ${ }^{24}$ The courts' approach assumes that even a disabled person can knowingly and intelligently waive her Miranda rights if her low IQ is counterbalanced by age, education, and experience with the police. ${ }^{25}$ Our results challenge this assumption. They suggest that even those disabled defendants with police experience, the one other factor that influenced scores, do not understand their Miranda rights. A person who is disabled does not understand the warnings, regardless of the other factors. Indeed, no disabled person in our sample understood the warnings adequately. ${ }^{266}$

Moreover, among the disabled group, those who were only mildly disabled did not understand the warnings substantially better than those who were severely disabled. If a subject was disabled, even just mildly, then the subject did not understand the warnings. Whether or not the subject was disabled determined understanding. The degree of disability had little impact.

Figure 17 presents regression results that demonstrate these two findings. It presents the score that a disabled person would be expected to obtain on each of the four measures of understanding if all other factors that influence understanding were favorable; given that a person is disabled, the figure sets forth the predicted scores for the person if the person possessed all of the other characteristics that increase understanding. We have seen that the two factors that can increase understanding are IQ and prior police contact. ${ }^{237}$ Thus, Figure 17 presents the predicted scores on the four measures of understanding for subjects who barely qualify as disabled, with IQs just below the cutoff of 70 , and who have had earlier contact with the police.

234 See text accompanying notes $163-65$.

235 See Part III.B.

236 See note 238 and accompanying text.

237 See Part IV.B.1; note 227 and accompanying text.

238 The predictions are based on the coefficients in the Statistical Appendix, Tables 12, 13, 14 , and 16. 
FIGURE 17

PREDICTED SCORES FOR SUBJECTS WITH MILDEST DISABILTY AND PRIOR POLICE CONTACT

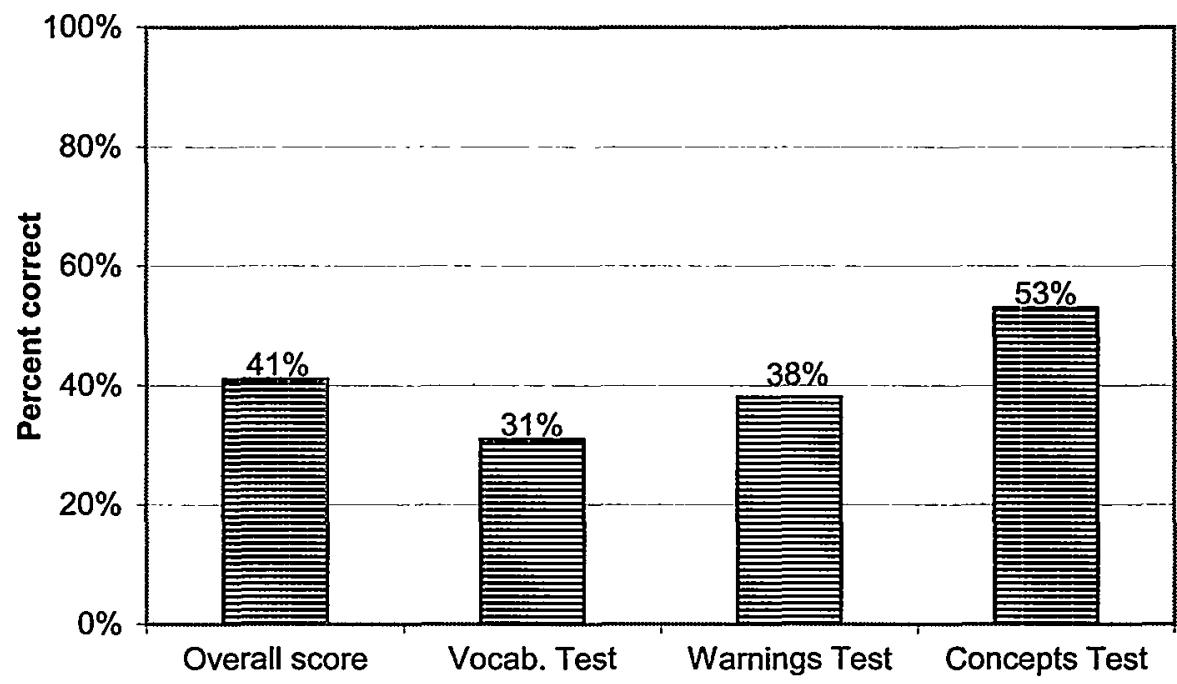

Even this best-case disabled person will not understand his Miranda rights. The person's predicted overall score is only 41 percent, with expected scores on the three individual tests of 31 percent, 38 percent, and 53 percent. As we saw above, ${ }^{239}$ being disabled reduced a subject's predicted overall score by 52 percentage points. Having a mild disability rather than a severe disability, or having prior police contact, increased the subject's expected score by far too little to make up for this and create real understanding. ${ }^{240}$ Contrary to the courts' typical assumption, the disabled do not understand their Miranda rights, regardless of how mild their disability is and regardless of other factors.

c) Results on bottom-line questions also contradict the courts' assumptions. Regression results for two bottom-line questions confirm that both of the courts' common assumptions are flawed. As part of the Warnings Test, we asked two questions that tested whether the subject understood one of the fundamental messages from the Miranda warnings: "Do you have to tell the police what happened?"

239 See Part IV.B.1.

240 An increase in IQ of twenty-five points, representing a change from being severely disabled to only mildly disabled, would increase total percent correct by only 20 percentage points. See Statistical Appendix, Table 12. Prior police contact would increase total percent correct by 10 to 12 percentage points. Id.

241 In our sample, the highest total score for any subject with an IQ below 70 was 60 percent. Other subjects with IQs approaching 70 had much lower total scores. For example, one subject with an IQ of 69 had a total score of 23 percent. 
and "Do you have to answer the police if they ask you any questions?" The stars in Figure 18 indicate which of the possible factors influenced whether the subjects answered the questions correctly.

FIGURE 18

REGRESSION RESULTS FOR INDIVIDUAL QUESTIONS

\begin{tabular}{|c|c|c|c|c|c|}
\hline & & \multicolumn{4}{|c|}{ Stars indicate significant influences on: } \\
\hline & & \multicolumn{2}{|c|}{$\begin{array}{l}\text { Correct answer on } \\
\text { "Do you have to tell } \\
\text { the police what } \\
\text { happened?" }\end{array}$} & \multicolumn{2}{|c|}{$\begin{array}{l}\text { Correct answer on "Do } \\
\text { you have to answer the } \\
\text { police if they ask you } \\
\text { any questions?" }\end{array}$} \\
\hline & & Column 1 & Column 2 & Column 3 & Column 4 \\
\hline & & $\begin{array}{c}\text { All } \\
\text { subjects }\end{array}$ & $\begin{array}{c}\text { Disabled } \\
\text { subjects }\end{array}$ & All subjects & $\begin{array}{l}\text { Disabled } \\
\text { subjects }\end{array}$ \\
\hline \multirow{8}{*}{ 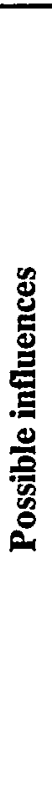 } & \begin{tabular}{|l|}
$\begin{array}{l}\text { Subject disabled } \\
\text { (IQ below } 90 \text { ) }\end{array}$ \\
\end{tabular} & & & & \\
\hline & IQ score & $\mathrm{NA}$ & & $\mathrm{A}$ & \\
\hline & Age & & & & \\
\hline & \begin{tabular}{|l|}
$\begin{array}{l}\text { Years of education } \\
\text { completed }\end{array}$ \\
\end{tabular} & & & & \\
\hline & \begin{tabular}{|l} 
Earlier contact with \\
police
\end{tabular} & & & & \\
\hline & $\begin{array}{l}\text { Earlier Miranda } \\
\text { warning }\end{array}$ & & & & \\
\hline & Race & & & & \\
\hline & Sex & & & & \\
\hline
\end{tabular}

In the regressions for both questions in which we used the entire sample, both disabled and nondisabled together, the only coefficient that was statistically significant was whether the subject was mentally retarded. ${ }^{243}$ Having a disability had a huge impact on understanding. As depicted in Figure 19, a disabled subject had only 1/100 the probability of answering the first question correctly as did a

242 Figure 18 summarizes the full regression results, which are found in the Statistical Appendix, Table 15.

243 We used a logistic specification because the dependent variable was a yes-no variable. 
nondisabled subject, and only $1 / 20$ the probability of getting the second question right. ${ }^{24}$ That is, on the fundamental lesson of the Miranda warnings that a defendant need not speak with the police, the nondisabled had from twenty times to one hundred times greater probability of understanding than the disabled, an order of magnitude difference.

\section{FIGURE 19}

Relative ProbabItTIES THAT DISABLED AND NONDISABLED ANSWER CENTRAL QUESTIONS CORRECTLY:

"Do you have to tell the police what happened?"

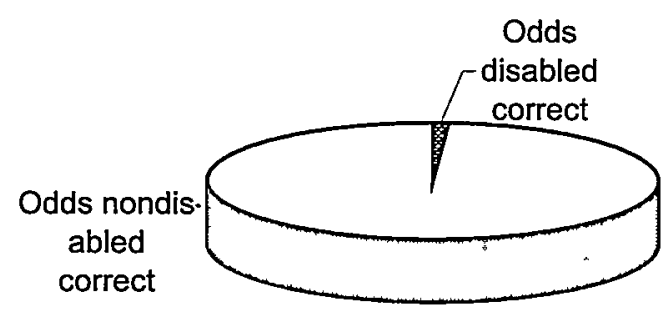

"Do you have to answer the police if they ask you any questions?"

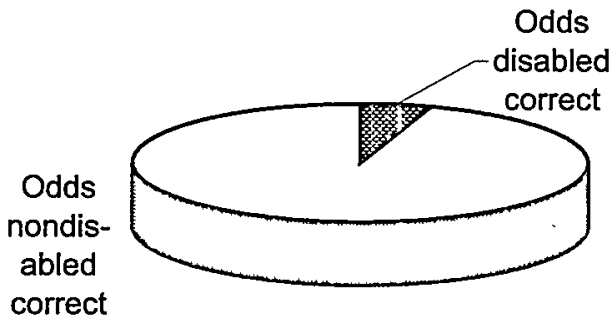

The results reject both of the courts' hypotheses. First, all of the variables other than disability, including all of the factors that courts typically use in their totality-of-the-circumstances test, failed to yield statistically significant coefficients. These results also necessarily reject the courts' second hypothesis. Because no factors other than disability significantly influence understanding, the other factors cannot counterbalance the lack of understanding from the disability.

244 The impact of IQ and disability as revealed in the regression is larger than in the means of our data. See Figure 2 . This is because the regression analysis permits us to isolate the impact of IQ and disability, holding all else constant. 
In regressions with only the disabled subjects, rather than everyone, the results in columns 2 and 4 in Figure 18 show that, on the bottomline issue of whether a defendant must speak to the police, none of the factors had a significant impact on the disabled subjects' understanding. ${ }^{245}$ If a subject was disabled, then the subject did not understand the Miranda warnings, regardless of where the subject's IQ lay within the range from 18 to 88 , and regardless of any of the other factors. ${ }^{246}$ The disabled simply do not understand.

Considering the results from Figure 18's columns 1 and 3 together with the results from columns 2 and 4 shows that the overriding influence on whether a person understands the bottom line of the warnings is whether he has a mental retardation. ${ }^{247}$ If he has a disability, then he does not understand the Miranda warnings. If they have no disability, then they probably understand the warnings. Among the subjects with a disability, none of the factors improved understanding. If the person is disabled, then it does not matter that the person has only a mild disability, that the person is old, has many years of education, has been arrested before, or has had the police earlier read him the warnings. The disabled person still does not understand the warning.

d) Many nonretarded people fail to understand. Eleven, or more than one-fifth, of our "disabled" subjects had IQs above the usual threshold of 70 . Like the subjects with scores below 70, this group did not understand their Miranda rights. For the subjects with IQs from 71 to 88 , the average total score was only 45 percent, with scores ranging from 21 percent to 76 percent. Even the highest total score among this group was too low to constitute the necessary understanding. ${ }^{245}$ Although only 11 people in our sample had IQs between 71 and 88 , their strikingly low scores are sufficient to suggest, and to do so with a high level of statistical significance, that this group does not have sufficient understanding of their rights. For example, even with our modest sample size, simple calculations indicate that, at more than a 95 percent level of statistical confidence, the true mean for this population is less than 77 percent $^{24}$-insufficient to constitute adequate understanding. Nonetheless, a study with more subjects in this group would be valuable to test these results.

245 See also Statistical Appendix, Table 15.

246 One subject with an IQ of 72 obtained a total score of 76 percent. No other subject with an IQ of 88 or below approached this level. Even this score was insufficient to indicate the necessary understanding. See text accompanying notes $236-41$.

247 Statistical Appendix, Table 15.

248 See note 246.

249 The standard deviation for this group's scores is 15.7 . 
The regression results confirm this group's lack of understanding. The results indicate that even a person with an IQ of 80 and prior experience with police would be expected to obtain an overall score of only 49 percent, far lower than the 87 percent that the nondisabled controls achieved. A suspect with an 80 IQ and without prior police experience would be expected to obtain a total score of only 38 percent.

This result challenges the Miranda decision's fundamental assumption, that nonretarded people who have been "Mirandized" will understand their rights. Although our results indicate that our controls of approximately average intelligence understand their rights, many nonretarded people of below-average intelligence do not. Only at some IQ above 88 but below the IQ of our control group do people begin to understand their rights.

The results suggest that each year thousands of nonretarded people of below-average intelligence are confessing and being convicted without the knowing and intelligent waivers that the Constitution requires. ${ }^{250}$ Prisons and death rows doubtless house many nonretarded people who failed completely to understand their right to silence, their right to an attorney, and the surrounding legal context.

\section{SOLUTIONS}

These empirical results demonstrate that the Miranda warnings are not "effective" for the population of mentally retarded people, and likely are ineffective for many nonretarded people of below-average intelligence. The empirical results also show that the totality-of-thecircumstances analysis as employed by the courts is inadequate to ensure that waivers and confessions by mentally retarded suspects satisfy constitutional standards. These data suggest that some additional protective mechanisms are needed when mentally retarded people are confronted with custodial interrogation.

Devising such mechanisms is a formidable undertaking. Crafting rules that protect individual rights while permitting law enforcers to perform their important functions is always difficult, and the special problems posed by mentally retarded suspects only complicate the problem. Consider, for example, the difficulties inherent in Professor White's proposal for screening juveniles and mentally retarded people before interrogation commences.

Because it is very likely that the government's use of standard interrogation methods on particularly vulnerable suspects will

250 For example, one study suggests that 16 percent of criminal defendants have IQs between 70 and 80 . See Grisso, Juveniles' Waiver of Rights at 214 table 3 (cited in note 22). 
produce untrustworthy confessions, the police should be required to determine the suspect's age and mental capacity before interrogation. Their findings should then dictate the range of permissible interrogation methods. For example, if a suspect is determined to be mentally retarded, the police should not be allowed to use the nine-step process described by the Inbau Manual. With these suspects, the police should be limited to asking nonleading questions and prohibited from insinuating that they believe the suspect is guilty.

Pre-interrogation screening would be relatively easy for police departments to implement with most juveniles, because age is a readily ascertainable objective fact. But identifying mental retardation is another matter. Just as it is beyond dispute that mental retardation makes people more vulnerable to these interrogation tactics, it seems indisputable that actors within the criminal justice process may fail to recognize a suspect's disability. "Individuals with mental retardation are not always easy to identify, especially those who function well socially, or attempt to disguise their disabilities.",233 Police officers, prosecutors, judges, and defense lawyers alike may fail to identify a suspect's disability until long after a confession has been secured.

It might be possible to compensate for this uncertainty on a caseby-case basis. For example, officers could operate under a "when in doubt, assume retardation" directive, commanding that "when officers suspect they have an offender with mental retardation, they should proceed as if the individual is mentally retarded until provided evidence to the contrary.",24 This solution is imperfect. First, it requires that officers be trained to identify mentally retarded suspects. Second, errors of over- and underinclusion inevitably will result.

Similar difficulties attend other common proposals for regulating interrogations, such as requiring the presence of a defense attorney, ${ }^{2 s}$ requiring that questioning be conducted by a judge or magistrate,

251 White, 32 Harv CR-CL L Rev at 142-43 (cited in note 34). The Supreme Court has recognized that, by virtue of the Due Process Clause, "certain interrogation techniques, either in isolation or as applied to the unique characteristics of a particular suspect, are so offensive to a civilized system of justice that they must be condemned." Moran $v$ Burbine, 475 US 412, $466 \mathrm{n} 62$ (1986), quoting Miller v Fenton, 474 US 104, 109 (1985). Accord Colorado v Connelly, 479 US 157,163 (1986).

252 See note 75 and accompanying text.

253 Bowker, 63 FBI L Enforcement at 13 (cited in note 40). See notes 88-90 and accompanying text.

254 Id.

255 See Grisso, 68 Cal L Rev at 1161-64 (cited in note 22).

256 See, for example, Albert W. Alschuler, A Peculiar Privilege in Historical Perspective: The Right to Remain Silent, 94 Mich L Rev 2625, 2669-70 (1996) (noting possible variations on pretrial interrogations by magistrates); Akhil R. Amar and Renee B. Letton, Fifth Amendment First Principles: The Self-Incrimination Clause, 93 Mich L Rev 857, 858-59 (1995) (suggesting benefits 
requiring exclusion of confessions resulting from custodial interrogation, ${ }^{257}$ requiring that interrogations be recorded, ${ }^{258}$ limiting the length of interrogations, ${ }^{259}$ or prohibiting trickery. ${ }^{260}$ Because of the identification problem, each of these remedies would protect all mentally retarded suspects only if required for interrogation of all suspects. Otherwise, some number of unidentified mentally retarded suspects would be interrogated without these safeguards.

It is not even certain that some of these proposals would be useful mechanisms for ensuring that confessions by mentally retarded suspects were knowing, intelligent, and voluntary. For example, interrogation by a judge or magistrate might induce a mentally retarded suspect to confess falsely in an attempt to please an authority figure who appears even more imposing than does a police officer, particularly if the questioning occurs in a courtroom. Because defense attorneys may be no more capable than are police officers of recognizing the existence of this disability, or of understanding the special problems confronting mentally retarded suspects, merely having a defense attorney present may not provide the assistance required by this unique population. ${ }^{261}$

of pretrial interrogations presided over by a judge or magistrate).

257 See Donald A. Dripps, Foreword: Against Police Interrogation - and the Privilege Against Self-Incrimination, 78 J Crim L \& Criminol 699, 727-28 (1988).

258 See White, 32 Harv CR-CL L Rev at 153-55 (cited in note 34) (citing numerous earlier sources recommending reform of interrogation practices).

259 See id at 143-45 (adducing empirical evidence to suggest that longer interrogations result in more false confessions); Yale Kamisar, Police Interrogation and Confessions: Essays in Law and Policy 98-99 (Michigan 1980) (noting Fred Inbau's classifications of interrogation trickery).

260 See White, 32 Harv CR-CL L Rev at 145-49 (cited in note 34) (arguing that certain kinds of police deception can sometimes convince even an innocent person of his own guilt).

261 A common solution proposed for resolving analogous problems arising from interrogations of juveniles is to require the presence of an attorney. See, for example, Steven A. Greenburg, Learning Disabled Juveniles \& Miranda Rights-What Constitutes Voluntary, Knowing, \& Intelligent Waiver, 21 Golden Gate U L Rev 487, 492 (1991); Holtz, 78 J Crim L \& Criminol at 541-42 (cited in note 180); Grisso, Juveniles' Waiver of Rights at 200-01 (cited in note 22); Grisso, $68 \mathrm{Cal} \mathrm{L} \mathrm{Rev} \mathrm{at} \mathrm{1161-64} \mathrm{(cited} \mathrm{in} \mathrm{note} \mathrm{21);} \mathrm{Grisso} \mathrm{and} \mathrm{Pomicter,} 1 \mathrm{~L} \&$ Human Beh at 341 (cited in note 22); Ferguson and Douglas, 7 San Diego L Rev at 50-54 (cited in note 176). Various national organizations have promulgated standards designed to provide special protection to juveniles in an interrogation setting. See, for example, National Advisory Committee on Criminal Justice, Task Force on Juvenile Justice and Delinquency Prevention, Standard 5.8: Guidelines for Interrogation and Waiver of Right Against Self-Incrimination 212-13 (1976) (recommending in particular that juvenile waivers of Miranda rights should only be effective when made with consent); National Advisory Committee for Juvenile Justice and Delinquency Prevention of the U.S. Department of Justice, Standards for the Administration of Juvenile Justice, Standard 2.247 (1980) (recommending that accused juveniles be made aware of particular rights in language understandable to them). The most widely used police interrogation manual has advocated that special protection must be afforded to juveniles and to all other persons of below-average intelligence to minimize the risk of obtaining untruthful admissions due to their vulnerability to suggestive questioning. See Grisso, Juveniles' Waiver of Rights at 1619 (cited in note 22) (discussing the possibility that interrogations of juveniles are inherently 
Post-interrogation review of a videotape of an interrogation may only reveal that officers utilized standard interrogation practices, without providing insights into the suspect's inability to comprehend the warnings or their significance. Indeed, the suspect's statement on the videotape that he understood the warnings could mislead those reviewing the tape into concluding that a mentally retarded suspect actually understood the warnings. Although each of these solutions may have benefits, the most rational way to pursue those benefits would to be to apply them in all cases, and not merely when a suspect has been identified as mentally retarded.

Rather than simply rehash the virtues and vices of these common proposals, ${ }^{2 / 2}$ we have attempted to identify solutions directed more precisely at the problem of assuring that confessions by mentally retarded suspects satisfy constitutional standards. We present five different proposals. None is perfect.

For example, only the first proposal, per se exclusion of confessions, would ensure that convictions of mentally retarded people cannot be based upon constitutionally invalid waivers. But this constitutional benefit is costly: it would eliminate confessions from an entire class of suspects. In contrast, two of the proposals could lead to a very different conclusion: disregard mental retardation and admit all

coercive); Grisso, $68 \mathrm{Cal} \mathrm{L} \mathrm{Rev} \mathrm{at} 1137$ (cited in note 22) (noting the vulnerability of juveniles in their dealings with police). Following these studies and new standards, many jurisdictions have adopted per se exclusionary rules for confessions by juveniles whenever certain initial safeguards have not been met. See Anthony J. Krastek, Comment, Judicial Response to Juvenile Confessions: An Examination of the Per Se Rule, 17 Duquesne L Rev 659, 660-61 (1978-79) (listing these jurisdictions). See also Custody Prior to Appearance before Magistrate, 18 USC $\$ 5033$ (1974) (mandating that rights be explained to the arrested juvenile and to her parent, and that the juvenile should be brought before a magistrate "forthwith"); Conn Gen Stat Ann § 46b-137(a) (West Supp 1981) (requiring that juvenile confession be ruled inadmissible unless rights were explained to arrested juvenile and her parent); Okla Stat Ann 10 \$1109(a) (West Supp 1979-80) (requiring presence of a parent); In re Dino, 359 So2d 586, 594 (La 1978) (holding that a waiver is per se inadmissible if the juvenile did not have the assistance of an informed and interested adult); Commonwealth v Smith, 372 A2d 797, 802 (Pa 1977) (holding that a minor's waiver is invalid when the minor is not "in fact provided an opportunity for consultation").

Of course, the Supreme Court has recognized the special vulnerability of juveniles during police interrogations. In re Gault, 387 US 1, 55 (1967) ("[T] greatest care must be taken to assure that the admission was ... not the product of ... adolescent fantasy, fright or despair."). See also Gallegos v Colorado, 370 US 49, 54 (1962) ("[A] 14-year-old boy, no matter how sophisticated, is unlikely to have any conception of what will confront him.").

262 No proposed solution receives more widespread support among Miranda's critics than does the use of technology to make a record of the interrogation. See, for example, Stuntz, 99 Mich L Rev at 981 n 19 (cited in note 9) (citing numerous commentaries and concluding that "[t]he need for video- and audiotaping is the one proposition that wins universal agreement in the Miranda literature"); Paul G. Cassell, $90 \mathrm{Nw}$ U L Rev at 486-92 (cited in note 5); Cassell, 99 Mich L Rev at 938-39 (cited in note 16) (proposing videotaping as a substitute for the warnings); id at 939 n 224 (citing proposals to use videotaping as a supplement for the warnings); Schulhofer, 99 Mich L Rev at 952-955 (cited in note 15) (proposing videotaping as a supplement to the warnings). 
confessions obtained in compliance with Miranda and without government coercion that would violate the traditional totalities test. Honest analysis of all five proposals ultimately emphasizes the difficulty of devising legal rules that will succeed at protecting the rights of mentally retarded suspects.

\section{Apply per se rules of exclusion.}

One possible solution is to adopt a per se rule of exclusion. In its broadest form, the rule would be: if custodial interrogation produces a confession from a mentally retarded suspect, the confession is inadmissible in subsequent judicial proceedings.

The justification for such a rule follows directly from our empirical research. Our results suggest that the class of people with IQ scores below 70 , and perhaps even 80 , does not understand the Miranda warnings, ${ }^{233}$ and the presence of other characteristics commonly considered in the totality analysis does not compensate for this fact. If the words "knowing" and "intelligent" are to have any rational meaning, it is impossible for a person who cannot understand the warnings to execute a valid waiver of his rights. Because the underlying justification for Miranda is that the knowledge imparted by the warnings ensures that confessions are voluntary and not the product of coercion, waivers by members of the class are not voluntary. Thus a per se exclusionary rule employs Miranda's own analysis, equating knowledge with voluntariness in a manner consistent with the acknowledged psychological propensities of mentally retarded individuals to succumb to pressures more readily than would people of at least average intelligence. ${ }^{254}$

This solution has a practical virtue: it creates a readily enforceable bright line rule. A judge would not have to make difficult decisions about whether a person with mental retardation was capable of understanding and waiving his or her Miranda rights. A judge also would not have to make the hard judgment of whether the police knew or should have known that the person had a mental retardation.

A global exclusionary rule has obvious costs. On the most practical level, a per se rule might impose additional administrative costs. For example, governments might be forced to incur the expense of giving an IQ test to every individual who is arrested and claims to be disabled, or whose behavior indicates that possibility. Of course, these costs might be minimized if the government and the defense rely upon preexisting records of the defendant's mental capacity. IQ tests

263 Although our study suggests that even people with IQs up to 88 may not understand the warnings, we round down to reduce the possibility of overinclusiveness.

264 See notes 13-16 and accompanying text. 
may have been administered previously in a setting where there is no reason to question the validity of the results. On the other hand, collateral attacks upon the results of the IQ tests also could occur, which would generate additional litigation and costs. As a practical matter, the same kinds of collateral litigation can occur under the present regime, so the problem of additional costs may be slight.

Another cost might, however, be significant. Exclusion of confessions might affect the government's ability to prosecute a case against an individual with mental retardation. This is a real problem and one that we do not take lightly, because confessions produced by custodial interrogation frequently provide evidence useful, if not essential, to the prosecution's case. In many cases, the government will have other evidence upon which to bring its case, and exclusion of a confession will likely have a minimal effect. In cases where the government's only evidence would be the individual's confession, the reality is that the government will be unable to prosecute a case effectively. This is an undeniable cost, but it is a cost offset by the danger that a mentally retarded person's confession may be false. In those cases, use of the confession can produce catastrophic effects, including the imprisonment or even the execution of innocent people.

Finally, the costs of a per se exclusionary rule emphasize the problem of identifying those suspects to whom it would apply. An IQ score of 70 is typically used as the marker for mental retardation. Yet IQ scores are unreliable, ${ }^{267}$ and our study demonstrates that some people with higher IQ scores are incapable of understanding the warnings. ${ }^{23 s}$ A suspect with an IQ score of 74 may be as likely to deserve the benefit of this rule as is one with a score of $70 .^{269}$

These problems suggest that it might be more desirable to adopt more limited per se rules. For example, it would be possible to exclude

265 See, for example, Cassell, $90 \mathrm{Nw}$ U L Rev at 438 (cited in note 5) (reporting that according to "reliable" studies confessions are necessary to conviction in about 24 percent of cases in which confessions are involved); Leo, $86 \mathrm{~J}$ Crim L \& Criminol at 280 (cited in note 11) (estimating that interrogations conducted in the 1990s produced useful incriminating statements in 64 percent of the cases).

266 See notes 34-38 and accompanying text. See also White, 32 Harv CR-CL L Rev at 108 n 26 (cited in note 34) (listing examples of studies' and suspects' claims "that standard interrogation techniques have led them to give false confessions").

267 Dr. Mel Levine, the prominent author and lecturer about brain function and learning, uses IQ tests and scores as an example of the "fallacy of misplaced concreteness," which he defines as an "abstraction that you have used so long that you forget it's an abstraction." This remark was made during a lecture at the Emory University School of Law (Sept 10,2001).

268 See Part IV.B.1.

269 For example, the Supreme Court has granted certiorari to decide whether the Constitution permits the execution of mentally retarded people, Atkins v Virginia, 2001 US LEXIS 5356, amended at 2001 US LEXIS 5463. 
any confession by a mentally retarded person unless other evidence - corroborated the confession. The existence of DNA or other corroborating scientific or physical evidence might be required. This type of rule has virtues for both the prosecution and the defense. It would allow prosecutors to use confessions substantiated by extrinsic, reliable evidence while protecting mentally retarded defendants from use of the most unreliable confessions. ${ }^{270}$

Nonetheless, this solution suffers from a notable doctrinal defect. It substitutes reliability for the constitutional standards governing waivers of rights. A confession can be truthful and yet not be the product of a knowing and intelligent waiver. To adopt a limited per se rule of this sort requires that we be willing to wink at the commands of current constitutional theory in the hope that the end results are worth the tradeoff. This kind of compromise is far from uncommon in constitutional law, and a method that reduces the likelihood of convictions based upon false confessions has much to recommend it. At least the words of the confession would be more likely to be meaningful-even if the command that the mentally retarded suspects' waiver of these rights must be knowing and intelligent would continue to be more myth than reality.

Inevitably, this would produce cases in which courts were forced to decide how to handle confessions that appear to be reliable, yet were the product of invalid waivers. One possible method of avoiding this problem would be to try to produce valid waivers by simplifying the warnings that mentally retarded people can understand.

\section{Administer simplified warnings.}

This solution would require law enforcement officers to administer warnings containing simplified synonyms for difficult words in the Miranda warnings. Our empirical study tested the capacity of mentally retarded people to understand such synonyms. Unfortunately, the results suggest that simplified warnings would be an ineffective means of addressing the problem. ${ }^{271}$

The mentally retarded subjects in our study understood the simplified vocabulary only slightly better than the original vocabulary

270 A traditional justification for excluding confessions has been unreliability. See, for example, John Henry Wigmore, 2 A Treatise on the Anglo-American System of Evidence in Trials at Common Law $\$ 822$ at $139-40$ (Little, Brown 2d ed 1923) (noting that experience demonstrates that innocent persons may sometimes view silence as a worse alternative than false confession).

271 The ineffectiveness of a simplified vocabulary is confirmed by studies of juvenile defendants. The studies show that a simplified vocabulary increased juveniles' understanding little. See Holtz, 78 J Crim L \& Criminol at 553-56 (cited in note 180) (developing a simplified "Youth Rights Form"); Ferguson and Douglas, 7 San Diego L Rev at 50-54 (cited in note 176) (finding simplified warnings do not significantly help the understanding of juveniles). 
of the warnings. As Figure 20 shows, considering results for all of the words together, they obtained an average of only 27 percent correct on the simplified vocabulary, compared to 20 percent correct for the regular Miranda vocabulary. In contrast, members of the nondisabled control group were correct for 83 percent of the Miranda vocabulary and 89 percent correct on the simplified vocabulary. ${ }^{2 m}$ Only 14 percent of the disabled subjects got at least partial credit on each of the simplified words, compared to 82 percent for the nondisabled control group.

272 These results also indicate that these simplified wamings produced comparably small increases in the understanding of the warning by those who have no disability. The simplified vocabulary increased the control subjects' average scoring on the vocabulary test by only 6 percentage points, compared to 7 percent for the disabled subjects. 
FIGURE 20

OVERALl PERformance ON MIRANDA WARNING AND

SIMPEIFIED WARNING
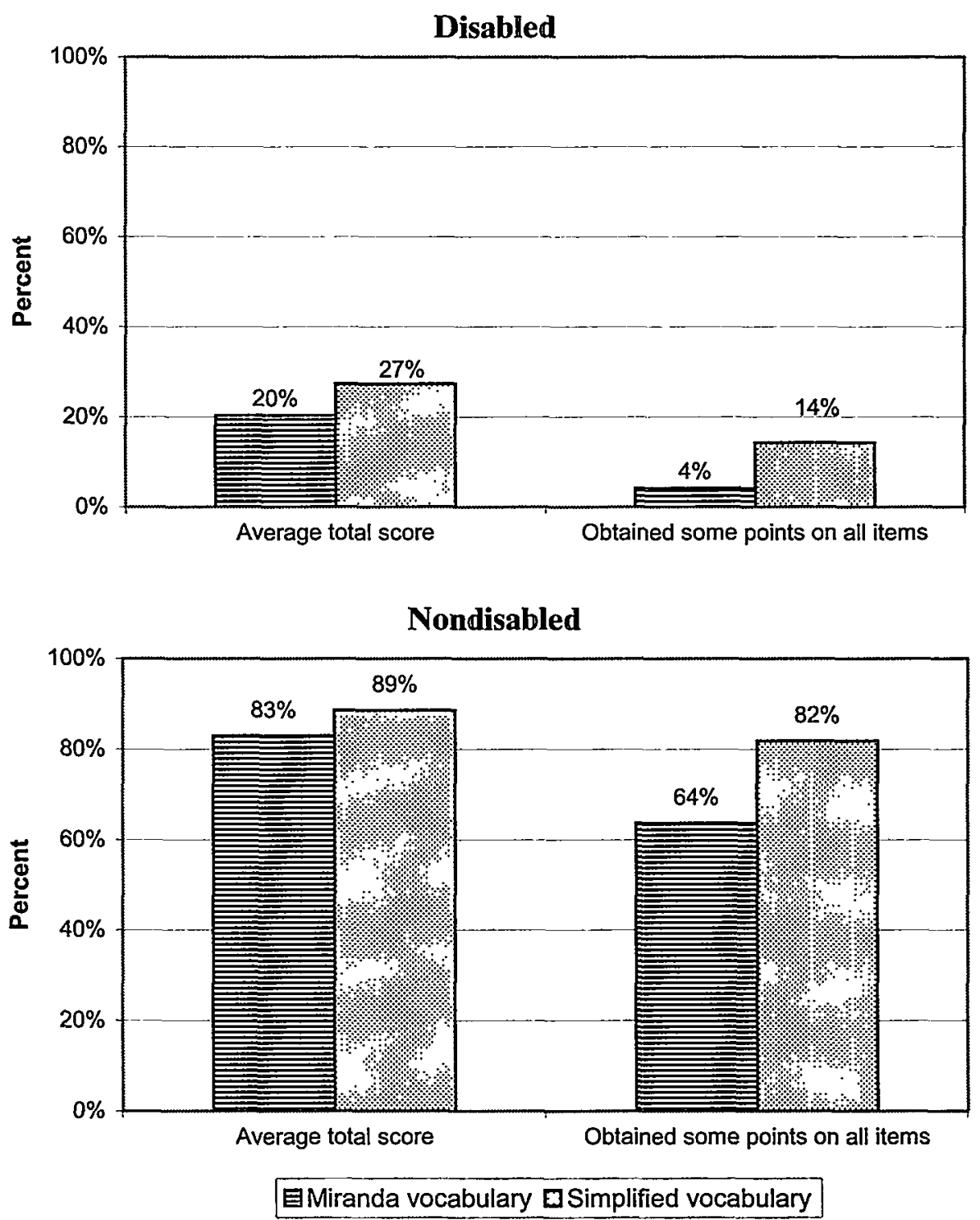

Like the overall scores, the results obtained for the individual words confirmed that the disabled subjects understood the simplified terms only slightly better than the original terms. For example, Figure 21 shows that although the average score for the disabled on understanding the original term "entitled" was only 16 percent, the average score for understanding the simplified term "deserve" was 
only 17 percent. ${ }^{2 / 3}$ Although the disabled subjects' improvement in the scores for the simplified vocabulary words ranged from 2 percent to 19 percent, the disabled subjects got more than 30 percent correct for only one of the simplified terms, and did not exceed 50 percent for any item. These data suggest that a simplified vocabulary would produce little overall improvement in mentally retarded persons' understanding of the individual terms contained in the warnings.

FIGURE 21

UNDERSTANDING MURANDA VOCABULARY AND SIMPLIFIED VOCABULARY: DISABLED SUBJECTS

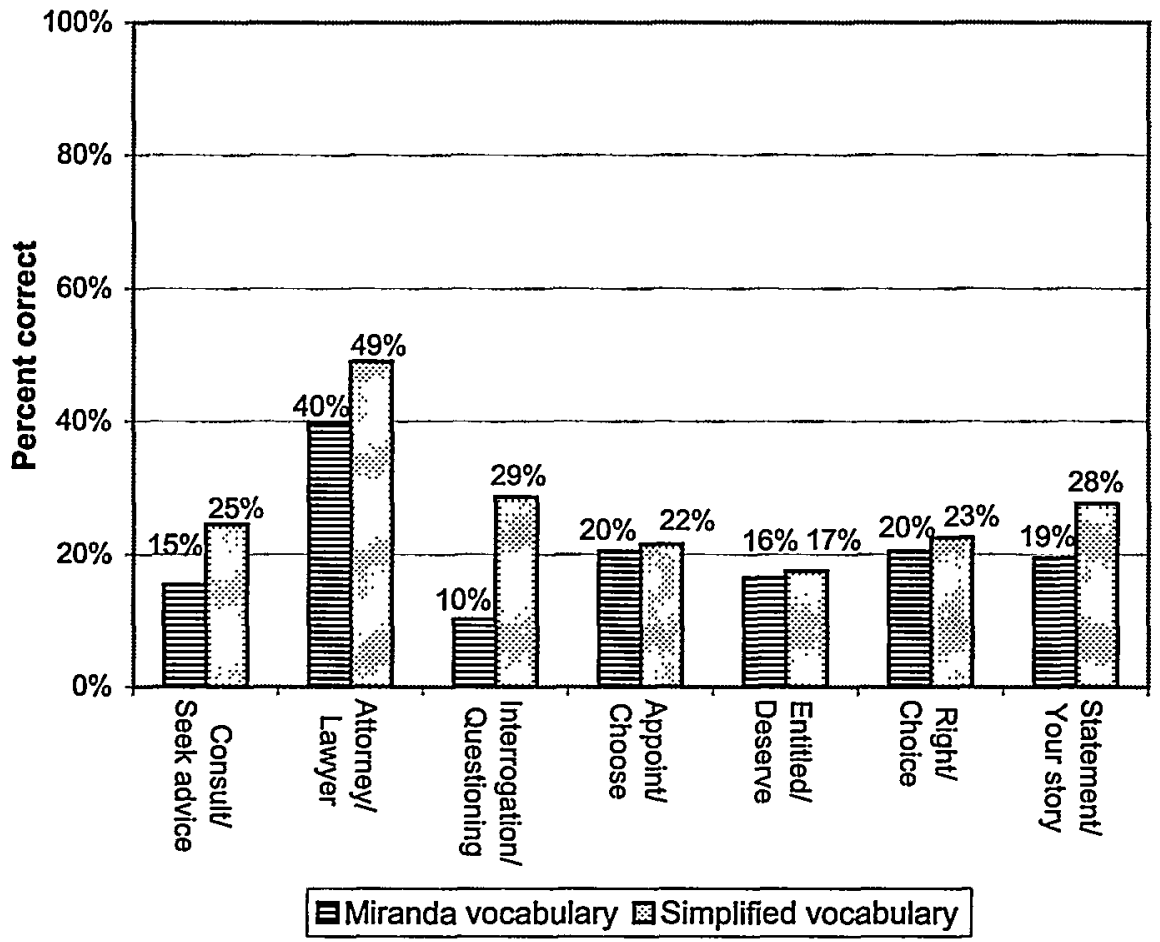

The results of our study suggest another reason that a simplified set of warnings would be ineffective at producing knowing and intelligent waivers. Even if mentally retarded people could understand the vocabulary of the warnings, the results of the Concepts Test suggest that they do not understand the workings of the legal system sufficiently to understand the contextual meaning of the warnings. The Concepts Test explored each subject's understanding of the goals of

273 Regression analysis shows that the simplified warning caused the greatest improvement in young subjects, and, to a lesser extent, in those with earlier police contact. See Statistical Appendix, Table 17. 
each party in an interrogation, the relationship between a suspect and his lawyer, and the functional environment for the right to silence. As Figure 9 shows, the disabled subjects had a poor understanding of the legal system and the respective roles played by the police, the disabled subject being interrogated, and the subject's guardian or attorney. The disabled subjects scored only 38 percent correct on this test, compared to 87 percent correct earned by the nondisabled controls. ${ }^{274}$

Merely simplifying the warnings would do little to provide most disabled people with the knowledge about the legal system that they need to understand either how the system functions or their rights within the system. For example, telling a disabled suspect that he can speak to a lawyer but need not speak to the police means little if the suspect does not understand that the lawyer represents the suspect, while the police and the suspect occupy adversarial roles.

One might argue that such a lack of understanding should not invalidate waivers. For example, in Colorado v Spring, ${ }^{275}$ the Supreme Court concluded that the "Constitution does not require that a criminal suspect know and understand every possible consequence of a waiver of the Fifth Amendment privilege., ${ }^{, 276}$ Whatever the merits of this conclusion, it should not govern cases in which the suspect lacks the mental capacity to understand the warnings. In fact, in Spring, the Court supported its conclusion that the defendant's waiver was knowing and intelligent by stressing that there was "no allegation that Spring failed to understand the basic privilege guaranteed by the Fifth Amendment. Nor [was] there any allegation that he misunderstood the consequences of speaking freely to the law enforcement officials." ${ }^{2 m}$ Once again, it is hard to find support for the validity of a waiver by a defendant who is incapable of understanding either the words of the warnings or the concepts they embody.

274 These results conflict with the judicial decisions concluding that, although mentally retarded defendants were incapable of understanding these concepts, their confessions were admissible because the police had given the suspects simplified versions of the warnings. See, for example, People $v$ Williams, 62 NY2d 285, 465 NE2d 327, 328 (1984) (holding waiver valid when suspect was capable of understanding the "immediate meaning" of the words of a simplified warning); Simpson v Commonwealth, 318 SE2d 386, 390 (Va 1984) (holding that the "clear and simple" language of the warnings issued was sufficient to offset the relatively low intelligence of the accused).

275479 US 564 (1987).

276 Id at 574.

277 Id at 575 (recognizing that the defendant claimed, to the contrary, that the waiver was not knowing and intelligent because the defendant had not been advised by law enforcers of the full scope of the interrogation). 
3. Modify the totality-of-the-circumstances analysis.

If the cognitive performance of mentally retarded suspects cannot be improved by simplifying the warnings, another possible method of ensuring that waivers by mentally retarded suspects satisfy constitutional standards would be to attempt to improve the totalityof-the-circumstances analysis used by the courts. This seems like a worthwhile endeavor, particularly because courts are almost certain to continue to apply the totality-of-the-circumstances analysis in the future. A close look at the history of the voluntariness analysis reveals that the totalities method is so embedded in this particular area of constitutional law ${ }^{273}$ that it would be hard to extirpate, even if this were the goal.

From a broader jurisprudential perspective, it is equally unlikely that judges will abandon this type of methodology. This type of "all things considered" analysis is precisely how our judges often go about resolving legal questions. ${ }^{2 \pi}$

If judges are certain to continue to employ this "all things considered" approach, it is sensible to attempt to make the analysis as accurate and reliable as possible. Unfortunately, the results of our empirical study of factors commonly relied upon by the courts indicate that mentally retarded defendants will not understand all of the Miranda warnings, despite the presence of the factors studied. ${ }^{230}$ If the courts had available only the factors they traditionally have emphasized, the data suggest that a "totality of the circumstances" analysis should contain but a single factor: the defendant's mental retardation. In effect, this brings us back to a per se approach in which the existence of the disability governs the admissibility of a confession.

One limitation in our study suggests a valuable topic for future research. Since we examined only five of the most common factors used by the courts, the results provide no information about how other factors might affect mentally retarded suspects' understanding of the warnings. A useful subject for future research would be to attempt to identify other factors that correlate with a mentally retarded person's capacity to comprehend either the Miranda

278 See notes $148-50$ and accompanying text.

279 See, for example, Schauer, Playing by the Rules at 176-80 (cited in note 50) (contrasting "rule-based" decisionmaking with "all things considered" judicial reasoning); Morgan Cloud, Pragmatism, Positivism, and Principles in Fourth Amendment Theory, 41 UCLA L Rev 199, 24547 (1993) (criticizing balancing but noting that it "now dominates major areas of constitutional law"); T. Alexander Aleinkoff, Constitutional Law in the Age of Balancing, 96 Yale L J 943, 965 (1987) (noting the dominance of balancing in Fourth Amendment and procedural due process analyses).

280 See Part IV.B. 
warnings or the significance of forsaking them. It is possible that additional factors could be identified to improve the effectiveness of the totalities test in ensuring that waivers are valid and confessions are voluntary.

Ultimately, this may well prove a fruitless endeavor, at least if the Miranda and Dickerson opinions mean what they say. Miranda held and Dickerson affirmed that when suspects face custodial interrogation, something more than the traditional totality-of-the-circumstances analysis is needed to ensure that their confessions are not the unconstitutional product of government pressure. Additional protections are needed to ensure that confessions and waivers of the right to remain silent are instead the product of the suspect's free choice.

Our data indicate that a disabled person's mental limitations prevent him from understanding the warnings, while those of above average intelligence are far more likely to comprehend their meaning. It is hard to understand from either a practical or a theoretical perspective how the totalities analysis that the Court presumed to be inadequate to ensure valid waivers by people of at least average intelligence would provide that assurance for the less cognitively competent population of mentally retarded suspects. The impact of retardation may be so significant that improving the waiver test will do nothing to ensure the constitutionality of waivers by mentally retarded people.

4. Reinvigorate the "knowing and intelligent" prong of the waiver test.

Some of the difficulty in evaluating waivers by mentally retarded suspects may result from imprecise application of the waiver test. In some cases, courts have obfuscated the "knowing and intelligent" prong of the waiver test while focusing solely on the existence of government coercion as a measure of voluntariness. In Colorado $v$ Connelly, the Supreme Court reversed a state supreme court's decision in a case involving confessions by a man who was mentally ill, not mentally retarded. The evidence suggested that the defendant's schizophrenia had produced command hallucinations that prompted his confessions. ${ }^{22}$ Relying upon the dual nature of the waiver test, the Supreme Court concluded:

[T] he proper test for admissibility is whether the statements are "the product of a rational intellect and a free will" [and] "the absence of police coercion or duress does not foreclose a finding 
of involuntariness. One's capacity for rational judgment and free choice may be overborne as much by certain forms of severe mental illness as by external pressure."2xo

Writing for the Court, Chief Justice Rehnquist rejected the conclusion that Connelly's undisputed mental illness prevented him from waiving his privilege against self-incrimination; ${ }^{224}$ his mental capacity apparently was irrelevant when evaluating the validity of his waiver of the privilege against self-incrimination. The Court focused upon the voluntariness element of the waiver test, and concluded that the validity of the waiver depended solely upon the presence or absence of government coercion. Compulsion from other sources, including the suspect's own mental illness, was irrelevant for Fifth Amendment purposes:

We think that the Supreme Court of Colorado erred in importing into this area of constitutional law notions of "free will" that have no place there. There is obviously no reason to require more in the way of a "voluntariness" inquiry in the Miranda waiver context than in the Fourteenth Amendment confession context. The sole concern of the Fifth Amendment, on which Miranda was based, is governmental coercion. Indeed, the Fifth Amendment privilege is not concerned "with moral and psychological pressures to confess emanating from sources other than official coercion." The voluntariness of a waiver of this privilege has always depended on the absence of police overreaching, not on "free choice" in any broader sense of the word. ${ }^{225}$

This analysis raises troubling issues, particularly when the individual who is interrogated is not mentally ill but instead is mentally retarded. A review of the scientific literature might lead to the conclusion that for many individuals, mental retardation makes them so vulnerable to the pressures of custodial interrogation that their waivers are not voluntary. ${ }^{2 s 5}$

Yet Connelly's singleminded focus on government coercion would seem to preclude a court from reaching this conclusion. Applied literally, Connelly's reasoning requires only that the warnings be administered, and absent evidence of some egregious police tactics, any waiver of the Miranda "rights" will be valid. As Chief Justice Rehnquist wrote in Dickerson, although the Miranda warnings do not "dispense with the voluntariness inquiry ...' [c] ases in which a

283 Id at 162, quoting People v Connelly, 702 P2d 722, 728 (Colo 1985).

284 See Connelly, 479 US at 170-71.

285 Id at 169-70 (citations omitted).

286 See Part II.B. 
defendant can make a colorable argument that a self-incriminating statement was 'compelled' despite the fact that the law enforcement authorities adhered to the dictates of Miranda are rare.","2s

The Connelly opinion thus appears to preclude most challenges to the validity of waivers on the grounds that they were involuntary because of a suspect's mental disability. At the same time, the opinion appears to preclude other constitutional challenges based upon the claim that the defendant's mental disability invalidates the waiver on grounds other than coercion:

Respondent would now have us require sweeping inquiries into the state of mind of a criminal defendant who has confessed, inquiries quite divorced from any coercion brought to bear on the defendant by the State. We think the Constitution rightly leaves this sort of inquiry to be resolved by state laws governing the admission of evidence and erects no standard of its own in this area. A statement rendered by one in the condition of respondent might be proved to be quite unreliable, but this is a matter to be governed by the evidentiary laws of the forum, see, e.g., Fed. Rule Evid. 601, and not by the Due Process Clause of the Fourteenth Amendment. "The aim of the requirement of due process is not to exclude presumptively false evidence, but to prevent fundamental unfairness in the use of evidence, whether true or false."208

As applied to mentally retarded suspects, this analysis cannot be right. The clinical and empirical research raises such serious questions about the intellectual and psychological capacities of this population, that an inquiry into "state of mind" not only is appropriate, but is essential in evaluating the validity of waivers of constitutional rights.

Nonetheless, Connelly's exclusive emphasis upon government coercion appears to have led some lower courts evaluating waivers by mentally retarded suspects to dismiss the significance of the "knowing and intelligent" dimension of the waiver test, and focus only on the question of government coercion. ${ }^{2 x 9}$ Some courts have concluded that retardation alone could not invalidate a confession. ${ }^{200}$ This is a

287 Dickerson, 530 US at 444, quoting Berkemer v McCarty, 468 US 420, 433 n 20 (1984).

288 Connelly, 479 US at 166-67 (citation omitted).

289 See, for example, Rice v Cooper, 148 F3d 747, 751-52 (7th Cir 1998) (noting that it may be beyond the practical competence of courts to find a confession involuntary in the absence of police coercion); Harris v Kuhlmann, 115 F Supp 2d 326, 333-36 (E D NY 2000) (adopting Rice's reasoning).

290 See, for example, Harris, 115 F Supp 2d at 335-36 (holding that a showing of mental retardation was insufficient to invalidate a confession without a further showing that the police knew the defendant did not understand his rights). See also Connelly, 479 US at 163-64:

Thus the cases considered by this Court over the 50 years since Brown v. Mississippi have focused upon the crucial element of police overreaching. While each confession case has 
conclusion that may be tenable if one considers only the voluntariness prong of the waiver test. But it is not sensible if we require that confessions also must be knowing and intelligent.

Some of the courts' lack of clarity about the distinction between the two lines of analysis may result from the conflation of the two elements of the waiver test-using warnings that at most could produce "knowing and intelligent" decisions to ensure they are "voluntary"-embedded in Miranda. Yet despite Miranda's commingling of these distinct issues, in a number of cases, the Court has recognized the dual nature of the inquiry. In Moran v Burbine, for example, the Court explicitly relied upon the dual nature of the waiver test, and quoted Miranda directly - to validate the defendant's waiver of Miranda "rights:"

Echoing the standard first articulated in Johnson v. Zerbst, Miranda holds that "[t]he defendant may waive effectuation" of the rights conveyed in the warnings "provided the waiver is made voluntarily, knowingly and intelligently." The inquiry has two distinct dimensions. First, the relinquishment of the right must have been voluntary in the sense that it was the product of a free and deliberate choice rather than intimidation, coercion, or deception. Second, the waiver must have been made with a full awareness of both the nature of the right being abandoned and the consequences of the decision to abandon it. Only if the "totality of the circumstances surrounding the interrogation" reveals both an uncoerced choice and the requisite level of comprehension may a court properly conclude that the Miranda rights have been waived. ${ }^{22}$

turned on its own set of factors justifying the conclusion that police conduct was oppressive, all have contained a substantial element of coercive police conduct. Absent police conduct causally related to the confession, there is simply no basis for concluding that any state actor has deprived a criminal defendant of due process of law. Respondent correctly notes that as interrogators have turned to more subtle forms of psychological persuasion, courts have found the mental condition of the defendant a more significant factor in the "voluntariness" calculus. See Spano v. New York, 360 U.S. 315 (1959). But this fact does not justify a conclusion that a defendant's mental condition, by itself and apart from its relation to official coercion, should ever dispose of the inquiry into constitutional "voluntariness."

See also Rice, 148 F3d at 751-52 (holding that the important inquiry is whether the police believed the defendant understood their explanation of his Miranda rights).

291475 US 412 (1986).

292 Id at 421 (citations omitted). Later in the opinion, the Court emphasized the dual nature of the inquiry:

Once it is determined that a suspect's decision not to rely on his rights was uncoerced, that he at all times knew he could stand mute and request a lawyer, and that he was aware of the State's intention to use his statements to secure a conviction, the analysis is complete and the waiver is valid as a matter of law.

Id at 422-23. 
This passage helps clarify how waivers by mentally retarded suspects should be evaluated. The question of whether a disabled individual possessed "the requisite level of comprehension" is precisely the question courts must ask whenever they are faced with this issue. It is essential that courts recognize that the issue of a suspect's intellectual understanding involves an inquiry distinct from the question of the voluntariness of the waiver. Consciously employing this two-stage process allows decisionmakers to focus on the proper questions and to pursue the necessary evidence.

Ironically, this brings us back to the beginning of the analysis of problems and solutions. Once we isolate the specific requirement that mentally retarded suspects must comprehend their legal rights to execute a valid waiver, we are forced to identify some method for ensuring that comprehension. Once again we face the reality that the Miranda warnings themselves do not accomplish this goal for mentally retarded suspects. And once again, we must determine whether the totalities analysis is adequate - a question our data answer in the negative.

Unless we can devise some other method that actually is "effective" at serving Miranda's instrumental goals, it is difficult to justify admission of confessions by mentally retarded suspects resulting from custodial interrogation. From the perspective of constitutional theory, this suggests that the appropriate solution is a per se exclusionary rule for these confessions.

Whatever its theoretical appeal, adoption of such a broad per se rule would require a radical revision of doctrine and practice. While it is far from impossible that the Supreme Court will adopt blanket rules to protect the rights of mentally retarded defendants, ${ }^{203}$ the underlying philosophy of Miranda and its progeny is to admit, not to exclude, confessions. ${ }^{294}$ Thus it seems reasonable to expect that if a per se rule were to be adopted, it would be more limited in scope.

293 See note 37 (discussing the Supreme Court's recent grant of certiorari to decide the constitutionality of executing mentally retarded defendants).

294 Recall that the Miranda majority eschewed any ban on custodial interrogations and devoted more than 10 percent of the opinion to evidence that the warnings would not hinder law enforcement efforts. See notes 135-39 and accompanying text. Miranda did not erect insurmountable barriers to confessions. To the contrary, the Miranda warnings now serve as a license for obtaining admissible confessions. Once a suspect has been "Mirandized" and executed a proper waiver of his rights, courts effectively presume that the confession was voluntary and therefore admissible. The Supreme Court confirmed this reality in Dickerson, where it noted that "'[c]ases in which a defendant can make a colorable argument that a self-incriminating statement was 'compelled' despite the fact that the law enforcement authorities adhered to the dictates of Miranda are rare." Dickerson, 530 US at 444, quoting Berkemer, 468 US at 433 n 20.

295 See notes 263-70 and accompanying text. 


\section{Abandon Miranda.}

For a third of a century, some Miranda critics have argued that it should be jettisoned because it interferes with the necessary efforts of law enforcers. Our study suggests that Miranda is just as subject to the opposite complaint-it fails to preserve the very rights it was designed to enforce. ${ }^{26}$ Our empirical study indicates that it fails to provide the basis for knowing and intelligent waivers, not only by retarded suspects, but also by many nondisabled suspects of below-average intelligence. The crucial assumption that underlies the Miranda framework - that being "Mirandized" will allow understanding of constitutional rights - appears to be false for virtually all mentally retarded suspects and some number of nonretarded suspects. Under Miranda, it seems inevitable that some defendants will be convicted, and in some cases even sentenced to die, based on confessions made without the knowing and intelligent understanding of rights that the constitution requires. Although our study suggests that the Miranda framework may serve the majority of nonretarded suspects, it also shows that it likely fails some percentage of that population.

Miranda has its advantages. It offers a convenient, easily applied rule that conserves judicial resources. Most observers have concluded that it facilitates the law enforcement goal of securing admissible confessions. However, our study suggests that the costs of this convenience may be too great. A system that fails in a substantial minority of cases might be acceptable if the stakes are small. However, because Miranda operates in the arena of criminal justice, where peoples' freedom and lives are in the balance, perhaps we should err on the side of establishing a new, more reliable system, even if the repair causes institutional expense and inconvenience.

The most obvious alternative to Miranda is the totalities analysis. Some of Miranda's most articulate critics have argued that a return to this traditional approach would better protect civil liberties than does the Miranda construct of warnings plus waivers. Any suspect might be permitted to argue that his confession should be excluded because he did not understand his Miranda rights, even though police read him the warnings and obtained a waiver. Under this analysis, a mentally retarded suspect might offer his disability as a basis for challenging the validity of his confession. Unfortunately, both the decisions of state and federal courts before and after Miranda, and the empirical results of our study, suggest that courts applying a totality-of-the-

296 This complaint is voiced with increasing frequency even by Miranda's most effective and articulate supporters. See, for example, Schulhofer, 99 Mich L Rev at 943 (cited in note 15) (asserting that the problem with Miranda is not that it shackles law enforcement, but that "the Miranda system is too weak"). 
circumstances approach are likely to overestimate the competence of mentally retarded suspects to understand their rights and to withstand the pressures of custodial interrogation.

\section{CONCLUSION}

Both theoretical analysis and empirical research demonstrate that the Miranda decision rests upon assumptions that are fundamentally flawed, at least when applied to mentally retarded people. This conclusion is of special importance because the Supreme Court's recent decision in Dickerson assures that Miranda will remain the centerpiece of constitutional analysis of confession law for the foreseeable future.

Miranda's theoretical deficiencies originate with its fundamental yet unverified assumption that the Miranda warnings work. If this assumption is wrong, the entire construct crumbles. Miranda then compounds the theoretical problem by blurring the critical distinction between the two prongs of the constitutional test for waivers. Miranda assumes that the information contained in the warnings not only supplies the information necessary to make a waiver "knowing and intelligent," but also ensures that the waiver is "voluntary." Unfortunately, the warnings satisfy neither element of the waiver test for people who lack the cognitive capacity to understand them.

The empirical research conducted in this study shows that contrary to Miranda's core assumption, retarded people simply do not understand their Miranda rights. They do not understand the words comprising the warnings. They do not understand the rights themselves. They do not understand the legal context in which the rights arise. Miranda fails to protect the rights of mentally retarded people, and it may fail for others as well. The results of our study suggest that people who are not classified as retarded, but who have low IQs, also may not understand the warnings.

Finally, the empirical results demonstrate that the totality-of-thecircumstances analysis courts typically use to determine whether mentally retarded suspects could understand the Miranda warnings also does not work. Factors including the degree of retardation, the mentally retarded suspect's age, education level, experience with the criminal justice system, and history of being "Mirandized" fail as indicators of a mentally retarded person's competence to understand the warnings and to execute a valid waiver. The results of the empirical analysis indicate that for this population the factor that matters is the presence of retardation, even mild retardation. If mental retardation is present, the existence of the other factors does not overcome the disabled person's inability to understand the warnings. 
Both our theoretical and empirical analyses lead to the conclusion that the language of the relevant constitutional doctrines is meaningless as it has been employed with mentally retarded suspects. The words of the Miranda warnings themselves are "meaningless" to mentally retarded suspects, who simply do not understand them. The words used to define the waiver test are "meaningless" in a different sense: they are applied to mentally retarded suspects in ways that contradict the very meaning of the words by which the standard is defined. Disabled suspects' waivers of the rights described in the Miranda warnings are "voluntary, knowing, and intelligent" only if we are willing to manipulate and distort the very meaning of these terms. ${ }^{207}$ Finally, the words of these confessions may themselves be meaningless. The cognitive and social weaknesses experienced by mentally retarded people ensure that some of their confessions will be false. When subjected to the pressures of custodial interrogation, mentally retarded people are more likely than others to confess to crimes they did not commit.

Perhaps the failure of current constitutional doctrine to ensure the validity of confessions and waivers by mentally retarded suspects should be no surprise. Legal rules are, after all, typically crafted with some average or "reasonable" person in mind. The results of this failure are troubling nonetheless. There seems to be little doubt that current doctrine not only permits unconstitutional waivers and false confessions, but also permits convictions-even death sentences-to be based upon those confessions.

Searching for solutions to this problem only accentuates the difficulty of identifying a set of rules or procedures that will protect the rights of these individuals while permitting law enforcers to carry on legitimate investigations. In the end, it may be that this accommodation is not possible. It may be that the only way to ensure the constitutional rights of mentally retarded suspects is to adopt a per se rule excluding their confessions. The cost of this approach is obvious: if the confession is true, then law enforcers and prosecutors are deprived of probative evidence. The cost of not adopting such a per se rule is just as obvious: confessions pried from the most vulnerable of our people may be false, and those false words may help send them to prison, or even to death row. In the end, we may be forced to decide if we can stomach that cost.

297 Consider the example offered by Lewis Carroll, Through the Looking-Glass, and What Alice Found There 124 (MacMillan 1872):

"I don't know what you mean by 'glory," Alice said. Humpty Dumpty smiled contemptuously. "Of course you don't-till I tell you. I meant 'there's a nice knock-down argument for you!" "But 'glory' doesn't mean 'a nice knock-down argument," Alice objected. "When $I$ use a word," Humpty Dumpty said, in rather a scornful tone, "it means just what I choose it to mean-neither more nor less." 


\section{PROTOCOL APPENDIX ${ }^{298}$}

\section{VOCABULARY TEST}

\section{A. Purpose}

To assess objectively an individual's understanding of the language of the Miranda warning. The first seven words appear in standard Miranda warnings. The second seven words are the type of language that might appear in a simplified warning.

\section{B. Directions}

The examiner should explain these directions to the interviewee. For example: "I am going to say a word and then use it in a sentence. Then I want you to tell me what that word means." The examiner should say the word. Then the examiner should read the designated sentence which uses the word. Then the examiner should ask what the word means. In certain circumstances, the examiner will have to ask follow up questions. Follow up questions should be limited to those discussed below.

\section{Consult. I want to consult him. What does "consult" mean?}

When the individual's response refers to talking, but without the idea of aid or advice (e.g., to discuss with someone), the examiner should ask, "How do you mean discuss?" When the individual gives a response that recognizes that discourse is involved, but does not mention the ideas of aid or advice, the examiner should say, "Give me an example of consulting someone."

If the individual's response is confusing because of double negatives, grammatical confusion, slang, or disorganization, the examiner should say, "Can you explain that a little more?"

2. Attorney. The attorney left the building. What does "attorney" mean?

When the individual only mentions that either the person is empowered to act for another in a legal process, that the person is especially trained in law and legal process, or only uses an accurate synonym (i.e. only mentions one of those three elements), the examiner should ask, "Is there anything else you can tell me about what an attorney is or does?"

If the individual's response is confusing because of double negatives, grammatical confusion, slang, or disorganization, the examiner should say, "Can you explain that a little more?"

3. Interrogation. The interrogation lasted quite a while. What does "interrogation" mean?

When the idea of investigation is conveyed, but without mentioning questioning, the examiner should say, "Please tell me more about what interrogation is." When other aspects of interrogation are mentioned, but not questioning, the examiner should say, "Please tell me more about what interrogation is."

If the individual's response is confusing because of double negatives, grammatical confusion, slang, or disorganization, the examiner should say, "Can you explain that a little more?"

4. Appoint. We will appoint her to be your social worker. What does "appoint" mean?

When the idea of action to get the person in a position is clear, but the idea of how this occurs is either nonessential or inappropriate (such as ideas of election to the position, paying someone to do the job, or to pass a law to put someone in a position), the examiner should say, "Please tell me more about what appoint means."

If the individual's response is confusing because of double negatives, grammatical confusion, slang, or disorganization, the examiner should say, "Can you explain that a little more?"

298 This protocol draws heavily on excellent earlier studies of juveniles, especially Grisso, Juveniles' Waiver of Rights (cited in note 22), and Ferguson and Douglas, 7 San Diego L Rev 39 (cited in note 176). See also note 176. 
5. Entitled. He is entitled to the money. What does "entitled" mean?

When the following specific answers are given without any addition-he has it, he will get it, or he can have it-the examiner should ask either, "Can you tell me more about that?" or "How do you mean (insert phrase used)?"

If the individual's response is confusing because of double negatives, grammatical confusion, slang, or disorganization, the examiner should say, "Can you explain that a little more?"

6. Right. You have the right to vote. What does "right" mean?

When the idea that one is allowed to vote is clear, but without the notion that the privilege to lay claim to the right is protected, the examiner should ask either, "Can you tell me more about what right means?" or "How do you mean (insert phrase used)?"

If the individual's response is confusing because of double negatives, grammatical confusion, slang, or disorganization, the examiner should say, "Can you explain that a little more?"

7. Statement. She made a statement. What does "statement" mean?

When the idea that it is told from the speaker's perspective is not clear, the examiner should ask, "Can you tell me more about what a statement is?"

If the individual's response is confusing because of double negatives, grammatical confusion, slang, or disorganization, the examiner should say, "Can you explain that a little more?"

8. Seek advice. He went to a friend to seek advice. What does "seek advice" mean?

When the individual's response refers to talking, but without the idea of getting aid or help (e.g., to discuss with someone), the examiner should ask, "How do you mean discuss?" When the individual gives a response that recognizes that discourse is involved, but does not mention the ideas of aid or assistance, the examiner should say, "Give me an example of seeking advice from someone."

If the individual's response is confusing because of double negatives, grammatical confusion, slang, or disorganization, the examiner should say, "Can you explain that a little more?"

\section{Lawyer. My friend works as a lawyer. What does "lawyer" mean?}

When the individual only mentions that either the person is empowered to act for another in a legal process, that the person is especially trained in law and legal process, or only uses an accurate synonym (i.e. only mentions one of those three elements), the examiner should ask, "Is there anything else you can tell me about what a lawyer is or does?"

If the individual's response is confusing because of double negatives, grammatical confusion, slang, or disorganization, the examiner should say, "Can you explain that a little more?"

10. Questioning. Her mother was questioning her about where she had been. What does "questioning" mean?

When the idea of being asked questions is conveyed with nothing more, the examiner should say, "Is there anything else you can tell me about questioning?"

If the individual's response is confusing because of double negatives, grammatical confusion, slang, or disorganization, the examiner should say, "Can you explain that a little more?"

11. Choose. We will choose him to be your assistant. What does "choose" mean?

When the idea of action to get the person in a position is clear, but the idea of how this occurs is either nonessential or inappropriate (such as ideas of election to the position, paying someone to do the job, or to pass a law to put someone in a position), the examiner should say, "Please tell me more about what choose means."

If the individual's response is confusing because of double negatives, grammatical confusion, slang, or disorganization, the examiner should say, "Can you explain that a little more?" 
12. Deserve. Anyone who is sick deserves the chance to go to the doctor. What does "deserve" mean?

When the following specific answers are given without any addition-he has it, he will get it, or he can have it-the examiner should ask either, "Can you tell me more about that?" or "How do you mean (insert phrase used)?"

If the individual's response is confusing because of double negatives, grammatical confusion, slang, or disorganization, the examiner should say, "Can you explain that a little more?"

13. Choice. You have the choice of whether to go to his house. What does "choice" mean?

When the idea that one is allowed to go is clear, but without the notion that the privilege to go cannot be taken away, the examiner should ask either, "Can you tell me more about what right means?" or "How do you mean (insert phrase used)?"

If the individual's response is confusing because of double negatives, grammatical confusion, slang, or disorganization, the examiner should say, "Can you explain that a little more?"

14. Your story. You had a chance to tell your story. What does "your story" mean?

When the idea that it is told from the speaker's perspective is not clear, the examiner should ask, "Can you tell me more about what your story is?"

If the individual's response is confusing because of double negatives, grammatical confusion, slang, or disorganization, the examiner should say, "Can you explain that a little more?"

\section{Grading}

Generally: Each answer will be given either a score of two, one, or zero based upon the description below.

1. Consult.

2 points: Conveys idea that information or advice is provided or sought pursuant to a decision.

Examples: To ask for (give) advice about something. To make plans with someone. To help to decide. Talk to make plans. To talk over problems.

1 point: Usually, the recognition of discourse is involved, but without the notion of aid, advice, or recognition of directed use of the discourse.

Examples: To discuss. To talk over. To talk confidentially. To talk to. To tell someone something. To ask a question. To help someone. To get information from someone (no improvement after inquiry).

0 points: States only the objective. Also, inaccurate meaning.

Examples: To insult. To decide. To plan something. To discover or find out.

2. Attorney.

Three elements:

a) Someone who is empowered to act for (and in the interest of) another person in legal proceedings.

Examples: The attorney is someone who's on your side. Someone who defends you. Who stands for your rights. He fights for you in court. Someone in your favor. Helps to get you out of trouble. Makes sure you get a fair deal.

b) Someone especially trained in law and legal process.

Examples: Somebody who knows everything about courts. He knows all about the law. He knows what your rights are. Someone who can interpret laws, knows what they mean. 
c) An accurate synonym.

Examples: Lawyer, public defender, counselor, legal counsel, legal consultant, or advisor.

2 points: Any response satisfying at least two of the elements listed above.

1 point: A response including only one of the three elements above.

0 points: $A$ response including none of the above elements.

Examples: An important person. A person who decides whether you are guilty or innocent. Someone who makes laws. A sort of policeman. A social worker.

3. Interrogation.

Formal definition: to ask questions formally; to examine by questioning

2 points: Idea of being questioned.

Examples: Questioning someone. When police ask you questions. When they ask you about whether or not you did the crime. When they put the lights on you and ask you to confess.

1 point: Idea of investigation without mention of questioning, or mention of other aspects which could be part of an interrogation.

Examples: An investigation of a crime. When they examine the evidence. When they tell you they think you did or didn't do the crime. When they brief (tell) you about what might happen to you if you did the crime.

0 points: Other legal processes, or clearly incorrect responses.

Examples: A hearing. Court day. When you go to court. Your trial. Being put in detention. I don't know what it means.

4. Appoint.

Formal definition: To ordain, prescribe; to name or select for an office or position.

2 points: The idea that a person is named, selected, assigned, told, or designated to do a job or fill a position.

Examples: To put someone on the case. To give someone the job. To get a person to do the job. To assign someone to the duty. To pick someone. To tell someone to do it. To name someone to do it.

1 point: The idea of action to get a person into a position, but with notions which are nonessential (and often too specific) regarding the idea of designation.

Examples: To recommend someone. To offer them money to do the job. To pass a law to put someone in a position. To examine someone to see if they can do the job. To elect someone to do it.

0 points: Wrong answers.

Examples: To point to someone. To help someone do something.

5. Entitled.

Formal definition: Given a claim or legal title to; qualified (to do something).

2 points: Notion of being qualified or deserving to do or receive something.

Examples: Has a right to do it. Deserves it. Should have (or get) it. Has it coming to him. It is owed to him. He is allowed to (get, have) it. No one is allowed to take it away from him. He owns it, it belongs to him. It is his.

1 point: Idea of possession, receipt, or action without notion or qualification or deservingness.

Examples: He has it. He will get (do) it. He can have it.

0 points: Wrong answers. 
Examples: What something is called. The title of something. To be attached to something. To want to have (do) something.

6. Right.

Formal definition: That to which a person has a just claim; a power, privilege, etc. that belongs to a person by law, nature, or tradition.

2 points: An action or condition which is allowed to a per6on, as well as the notion that this privilege is protected, "inalienable," or not able to be denied arbitrarily by others.

Examples: It means you can do something no matter what. By law, if you qualify, you can do it if you want. You can legally do it even if someone else doesn't like it. You can do it because you were born here. You are entitled to it.

1 point: The idea of being allowed to do something, without the notion of protection of one's privilege to lay claim to that allowance.

Examples: You can do it. You're allowed to do that. You can if you want to. You can do it without asking. It's your decision. It is your privilege.

0 points: No recognition of allowance or privilege.

Examples: Your right hand. Left, right. Like you should vote, it's important to do that. Means something is the right thing to do.

7. Statement.

2 points: Recognition that it is what happened told from the individual's perspective.

Examples: It is when you tell your story. When you tell your side.

1 point: Recognition that it is something someone says.

Examples: When someone says something. When someone talks.

0 points: Wrong answers.

Examples: It is what you are told to say.

8. Seek advice.

2 points: Conveys idea that information or aid is provided or sought pursuant to a decision.

Examples: To ask for (give) help about something. To make plans with someone. To help to decide. Talk to make plans. To talk over problems.

1 point: Usually, the recognition of discourse is involved, but without the notion of aid, advice, or recognition of directed use of the discourse.

Examples: To discuss. To talk over. To talk confidentially. To talk to. To tell someone something. To ask a question. To help someone. To get information from someone (no improvement after inquiry).

0 points: States only the objective. Also, inaccurate meaning.

Examples: To insult. To decide. To plan something. To discover or find out.

9. Lawyer.

Three elements:

Someone who is empowered to act for (and in the interest of) another person in legal proceedings.

Examples: The lawyer is someone who's on your side. Someone who defends you. Who stands for your rights. He fights for you in court. Someone in your favor. Helps to get you out of trouble. Makes sure you get a fair deal.

Someone especially trained in law and legal process. 
Examples: Somebody who knows everything about courts. He knows all about the law. He knows what your rights are. Someone who can interpret laws, knows what they mean.

An accurate synonym.

Examples: Attorney, public defender, counselor, legal counsel, legal consultant, or advisor.

2 points: Any response satisfying at least two of the elements listed above.

1 point: A response including only one of the three elements above.

0 points: A response including none of the above elements.

Examples: An important person. A person who decides whether you are guilty or innocent. Someone who makes laws. A sort of policeman. A social worker.

10. Questioning.

2 points: Idea of being asked for information and being investigated.

Examples: Being asked for information for someone. When someone ask you a lot of questions. When they ask you about whether or not you did something.

1 point: Idea of questioning without the idea of trying to get information or investigating.

Examples: When someone asks something to see if you know the answer.

0 points: Other legal processes, or clearly incorrect responses.

Examples: A hearing. Court day. When you go to court. Your trial. Being put in detention. I don't know what it means.

11. Choose.

2 points: The idea that a person is named, selected, assigned, told, or designated to do a job or fill a position.

Examples: To put someone on the case. To give someone the job. To get a person to do the job. To assign someone to the duty. To pick someone. To tell someone to do it. To name someone to do it.

1 point: The idea of action to get a person into a position, but with notions which are non-essential (and often too specific) regarding the idea of designation.

Examples: To recommend someone. To offer them money to do the job. To pass a law to put someone in a position. To examine someone to see if they can do the job. To elect someone to do it.

0 points: Wrong answers.

Examples: To help someone do something.

12. Deserve.

2 points: Notion of being qualified or deserving to do or receive something.

Examples: Has a right to do it. Deserves it. Should have (or get) it. Has it coming to him. It is owed to him. He is allowed to (do get, have) it. No one is allowed to take it away from him. He owns it, it belongs to him. It is his.

1 point: Idea of possession, receipt, or action without notion or qualification or deservingness.

Examples: He has it. He will get (do) it. He can have it.

0 points: Wrong answers.

Examples: It is dessert. It is a hot place. To want to have (do) something. 
13. Choice.

2 points: An action or condition which is allowed to a person, as well as the notion that the decision is one that cannot be taken away.

Examples: It means you can do something no matter what. By law, if you qualify, you can do it if you want. You can legally do it even if someone else doesn't like it. You can do it because you were born here. You are entitled to it. You can make up your own mind to do or not do something.

1 point: The idea of being allowed to do something, without the notion of the decision to do it being protected.

Examples: You can do it. You're allowed to do that. You can if you want to. You can do it without asking. It's your decision. It is your privilege.

0 point: No recognition of allowance or privilege.

Examples: It is something you have to do. It is what someone wants you to do. Means something is the right thing to do.

14. Your Story.

2 points: Recognition that it is told from the individual's perspective.

Examples: It is when you tell what you think happened. When you tell your side.

1 point: Recognition that discourse is involved, but not that it is told from the individual's perspective.

Examples: When you tell the story of your life. When you tell something.

0 points: Wrong answers.

Examples: It is what you are told to say.

\section{WARNINGS TEST}

\section{A. Generally}

This section tests the individual's comprehension of the Miranda warnings as they are currently worded. The examiner will read a sentence of the Miranda warning to the individual while the individual can follow along with a written card. The written card is left on the table. The examiner will then read the sentence from a second card to the individual, who will have to determine whether the second sentence means the same thing or something different than the first sentence. Repeat this procedure three times for each sentence of the Miranda warning.

\section{B. Administration}

The examiner should instruct the individual: "Now I am going to show you some sentences. After I read a sentence to you, I will read three more statements. Each statement means either the same thing or not the same thing as the first sentence. I want you to tell me whether each statement is the same or different from the sentence on the card. I will then ask you three yes/no questions about each sentence." After the examiner gives the instructions, he should perform the examples: "Here are two examples so that you know what to do. This sentence says, 'I have volunteered to be in this study.' Now look at this card. 'I have agreed to take this test and nobody forced me to do it.' Now does that card say the same thing or something different from the first sentence?" If the individual says "same," proceed to the second example. If the individual says "different," explain why they are the same, and go on to the second example. The examiner continues: "Here is the next card. The sentence says, ' $I$ have to take this test whether I want to or not.' Is this the same as the first sentence?" If the interviewee says "same," give a zero for all questions requiring the same/different answer, and only ask the yes/no questions. If the interviewee answer "different," administer both the same/different questions and the yes/no questions. 
C. Grading

One point is given for every correct answer and 0 points are given for every incorrect answer.

1. Miranda Sentence 1: You do not have to make a statement and have the right to remain silent.

Sentences and answers:

It is not right to tell lies. Different.

You should not say anything until the police ask you questions. Different.

You do not have to say anything about what you did. Same.

Questions and answers:

Do you have to tell the police what happened? No.

If you want to, can you talk to the police before they ask you any questions? Yes.

Do you have to answer the police if they ask you any questions? No.

2. Miranda Sentence 2: Anything you say can and will be used against you in a court of law.

Sentences and answers:

What you say might be used to prove you guilty. Same.

If you won't talk to the police, then that will be used against you in court. Different.

If you tell the police anything, it can be repeated in court. Same.

Questions and answers:

If you talk to the police, can they repeat what you say in court? Yes.

If you talk to the police, can they use your story to get you in trouble? Yes.

If you do not talk to the police, can they get you in trouble for not talking? No.

3. Miranda Sentence 3: You are entitled to consult with an attorney before interrogation and to have an attorney present at the time of the interrogation.

Sentences and answers:

You can talk to your social worker before anything happens. Different.

A lawyer is coming to see you after the police are done with you. Different.

You can have a lawyer now if you ask for one. Same.

Questions and answers:

Will a lawyer automatically come to see you after you talk to the police? No.

Can you get a lawyer before you talk to the police if you want one? Yes.

Will you get an attorney in the interrogation with you if you don't ask for one? No.

4. Miranda Sentence 4: If you cannot afford an attorney, one will be appointed for you.

Sentences and answers:

If you don't have the money for a lawyer, then the court will appoint a social worker to help you. Different.

You can get legal help even if you are poor. Same.

The court will give you a lawyer free if you don't have the money to pay for one. Same. 
Questions and answers:

If you are poor, can you get an attorney? Yes.

Will it cost you money to get an attorney if you are poor? No.

Do you have to have money to get an attorney? No.

\section{CONCEPTS TEST}

Purpose. To identify an individual's understanding of the legal concepts involved in the Miranda warning.

Directions. Four different scenarios are drawn on cards. The interviewer then says: "I am going to show you several pictures of people doing things. After I tell you something about a picture, I will be asking you questions about what you think the people in the picture could be doing and thinking and feeling. With these questions, it is best if you just give me a short answer." The card is given to the individual to look at, while the interviewer presents a brief verbal "story" to establish a context for the questions. After the story, the examiner will follow-up with questions.

A. Card 1: Joe's interrogation

Description: The card will depict a scene of a boy sitting at a table across from two police officers. The questions are all related to understanding the nature of interrogation.

Story: "This is a picture about a boy named Joe. The policemen in the picture have brought Joe into the police station. There has been a crime. The policemen want to talk to Joe. Remember that Joe is in the police station and the policemen want to talk to him."

Questions and follow-up questions:

1. Q1: What is it that the policemen want Joe to do?

If individual answers talk or answer questions without an indication of the topic, examiner should ask, "About what?"

If the individual does not mention talking or questioning, the examiner should ask, "What important thing might the policemen ask Joe to do?"

2. Q2: Finish this sentence. The police think that Joe

3. Q3: What is the most important thing that the police might want Joe to tell them?

If the individual does not mention anything about potentially incriminating information, the examiner should ask, "What other important thing?"

If the individual mentions the truth, the examiner should ask, "About what?"

4. Q4: How are the policemen probably feeling?

For all responses, examiner should ask, "Why are they feeling that way?"

5. Q5: How is Joe probably feeling?

For all responses, examiner should ask, "Why is he feeling that way?"

If the individual does not refer to being affected, the examiner should ask, "How is he feeling about what is happening to him now?"

B. Card 2:Tim and His Lawyer

Description: The card depicts a boy and a lawyer in consultation in a room. The questions are all related to the understanding of the function and the significance of the right to counsel.

Story: "This is Tim. He is in the police station, too, because the police think he broke into a house. The police have not questioned him yet. Here Tim is meeting with his lawyer. The lawyer is asking Tim some things before Tim goes to be talked to by the police. Tell me what you think might happen here." 
Questions and follow-up questions:

1. Q1: What is the main job of the lawyer?

If the individual mentions asking questions and discovering information but does not indicate whether this is to provide a benefit to Tim, the examiner should ask, "Why does the lawyer do that?" or "Can you tell me more?"

If the individual's response suggests that the lawyer helps only the innocent, the examiner should ask, "And what is his job if Tim is not innocent?"

2. Q2: While he is with his lawyer, what is Tim supposed to do?

When the individual only mentions talking, the examiner should ask, "Can you tell me more?" or "Talk about what?"

When the individual only mentions compliance, the examiner should ask, "Can you tell me more about what Tim is supposed to do?"

3. Q3: What is main thing Tim's lawyer will be talking to Tim about?

4. Q4: Imagine that Tim's lawyer is saying, "I want you to tell me exactly what you did and tell me the truth about what happened." Then Tim tells him that he did the crime. Why would Tim's lawyer want to know that?

If the individual mentions for the purpose of getting information but not for assistance, the examiner should ask, "Why would the lawyer want to know that?"

If the individual's answer does not make clear that the lawyer's actions are to help Tim, the examiner should ask, "Why would the lawyer want to do that?"

C. Card 3: Greg's Interrogation

Description: The card depicts a boy entering an interrogation room accompanied by two police officers. The questions regard the function and significance of the right to silence.

Story: "This is Greg. The police have taken him to detention because they want to talk to him. Greg stole some money from a store, but the police are not sure he did it because nobody saw Greg do it. They are getting ready to ask him questions. Greg knows he doesn't have to talk if he doesn't want to, and he is trying to decide whether or not to talk."

Questions and follow-up questions:

1. Q1: Finish this sentence. If Greg decides to tell the police about what he did, then the things he says

If the individual's answer only mentions that it can cause him trouble or be held against him but does not make any reference to court, the examiner should ask, "Can you tell me more?" or "In what way?"

2. Q2: If Greg decides not to talk, what is the most important thing the police are supposed to do?

If the individual's answer only mentions detainment, the examiner should ask, "What other important thing?"

3. Q3: Finish this sentence. If the police tell Greg he has to talk even if he has said he doesn't want to, then

If the individual's answer only mentions that he won't/shouldn't/ won't want to talk without further elaboration, then the examiner should ask, "Why won't/shouldn't he talk?"

If the individual's answer mentions that Greg will or should talk but gives no mention of the conflict with rights or no statement of why Greg will talk, the examiner should ask, "Can you tell me more?" 
If the individual's answer is ambivalent about whether Greg will talk and gives no mention of the conflict with rights, the examiner should ask, "What should Greg do and why should he do it?"

If the individual's answer is that Greg will attempt to subvert police demands in a way other than asserting his rights (i.e. will tell a lie, will try to kill himself, etc.), the examiner should ask, "Can you tell me more about that?"

If the individual's answer is that Greg will be detained or locked up without any elaboration, the examiner should ask, "Why?"

\section{Card 4: Greg's Court Hearing}

Description: The card depicts a courtroom hearing with judge, police officers, parents, the individual's lawyer, and the individual. The questions regard the function of the right to counsel and the right to silence.

Story: "This is Greg three weeks later. He is at his court hearing. The judge is here, and the policemen who arrested and questioned Greg are here. Greg's lawyer and his parents are sitting near him."

\section{Questions and follow-up questions:}

1. Q1: If Greg's lawyer did just what he is supposed to do here in court, how would Greg be feeling?

If the answer only mentions a negative effect or outcome and does not refer to the lawyer's role, the examiner should ask, "How does Greg feel about what the lawyer is doing?"

For all responses, the examiner should ask, "Why would he feel that way?"

2. Q2: What is supposed to happen when the judge is told that Greg would not talk to the police?

If the individual's response is that the judge will ask Greg questions, the examiner should ask, "What if Greg still will say nothing?"

3. Q3: Greg did not tell the police anything about what he did. Here in court, if he were told to talk about what he did that was wrong, will he have to talk about it?

For all responses, the examiner should ask, "Why?"

\section{GRADING FOR PART III CONCEPTS TEST}

Generally. The response to each question will receive either two, one, or zero points. Generally, a 2-point response shows the individual understood the function or significance of the element in question. Vague or partial responses which cannot be clearly viewed as correct or incorrect are given 1 point. Responses which demonstrate a lack of understanding of the function or significance of the element in question are given zero points. The grade should be given after the follow-up question. For example, if an original answer would be graded as one point and the response to the follow up question would be given 2 points, then 2 points should be given. If the original answer would have been given 1 point and the follow up question would have been given 0 points, then 0 points should be given. Note, however, that it is rare that a 0 would go to a 2 or a 2 to a 0 after a follow-up question.

\section{A. Card 1: Joe's Interrogation}

1. Q1: What is it that the police will want Joe to do?

2 points: Clear indication that the police desire a confession, or to acquire information about Joe's actions at the time of the crime.

Examples: Tell them where he was at time of the crime. To tell why he did it. To tell who he was with when he stole the stuff. Say he did something. Nark on people. Tell where he was at a certain time. Tell them what happened. 
1 point: Statement that police want suspect to talk, but without clear mention of the nature of the information sought.

Examples: Talk about something. Tell them something. Talk, but he won't answer some questions. Give some information. Make a statement. Tell the truth.

0 points: Reserved for responses which include no mention of talking, confession, or providing information specific to the question of one's alleged criminal/delinquent involvement.

Examples: Act with good manners. Stay in detention for a while. Sign some papers so they will know who Joe is. Behave himself. Never get in trouble again. Listen.

2. Q2: Finish the sentence. The policemen think that Joe

2 points (Responses may be of three types, and an answer with any of the types receives 2 points.):

Police see Joe as probably guilty of alleged criminal act, or probably involved in such a way that he has knowledge of alleged act.

Examples: Committed a crime. Had something to do with a crime. Did a bad thing. Stole a TV from a house. Is a criminal. Is guilty. Is part of a gang.

Police see Joe as non-cooperative, as withholding information, or as not trustworthy.

Examples: Is telling a lie. Is holding back information. Can't be trusted.

Police perception of Joe as untrustworthy or involved in criminal act is implied, but not clearly stated.

Example: Belongs in detention. Did something. Got too involved in something.

1 point: Police see youth as probably guilty, but not fully responsible for his actions (thus reducing adversary conditions).

Examples: Is crazy. Is sick. Has just fallen in with bad company. Needs a psychiatrist.

0 points: Police are sympathetic with suspect, or do not see him as guilty.

Examples: Is not really bad. Is okay. Is not guilty. Needs their help and they can help him.

3. Q3: What is the most important thing the police might want Joe to tell them?

If subject obtained 2 point credit on Question 1, skip this question and give an automatic 2-point credit for this question.

2 points: About Joe's involvement in or knowledge of a crime.

Examples: Whether he did it or not. About what he was doing before they picked him up. Whether he knows who did the crime. Whether there were friends involved with him.

1 point: The truth.

0 points: Moralistic or relatively non-incriminating information.

Examples: Why he's so bad. Where he lives. What his name is. Whether or not he wants to go home.

4. Q4: How are the police probably feeling?

2 points: Affect/reasoning of the subject's response reflects police intentions to deal with the youth as an adversary. 
Angry.

Examples: Angry 'cause Joe won't talk. Aggravated. Upset because they have to go through all this.

Good, self-satisfied.

Examples: Happy. Good. Proud. Happy 'cause they caught somebody doing wrong. Like they are really something. Superior.

Justified.

Examples: That he did it. That he's guilty. That he ought to be put in jail. Frustrated.

Examples: That he's not cooperating. That he is lying. That he won't tell the truth. Like they want to smack him.

1 point: Not applicable.

0 points: Emotions which are inconsistent with adversary quality of interrogation, or don't know, or mixed responses.

Examples: I don't have any idea. Embarrassed. Sorry for him. Sad about the boy. Joe needs help very bad. Real bad about it, because they didn't want to upset him. Mad, because they don't want to have to do this to Joe. If he did it, they feel mad at him, but if they framed him, they feel bad and are going to help him out.

5. Q5: How is Joe probably feeling?

2 points: Negative emotions appropriate for the accused in an adversary situation.

Examples: Very mad. Sad. Like a criminal. Scared. Miserable. Dumb. Like a chump. Like he shouldn't have done what he did. That his parents are going to be upset. Sorry.

1 point: Not applicable.

0 points: Feelings not reflecting the adversary process.

Examples: Pleased. Good. All right. Like everything is ok.

B. Card 2: Tim's Lawyer

1. Q1: What is the main job of the lawyer?

2 points: Any response indicating clearly that the lawyer is to assist or work in the interests of the client.

Examples: Help Tim. Protect Tim's rights. Defend Tim. Help Tim get out. Get Tim off the hook. To get everyone to believe Tim. To help Tim understand what is going on and to help him through it. To help him get out of detention. Give him some clues that can help Tim get out of trouble.

1 point: Responses referring to some portion of the process by which the lawyer works on behalf of a client, but the idea of helpfulness or assistance is not clearly conveyed (response could also apply to interrogator).

Examples: Find out as much as he can. Find out what happened. Find out if Tim did it. Get Tim to trust him. Find out the truth from Tim.

0 points: Responses placing the lawyer in a role contrary to an advocate for the client (response implies lawyer as an adversary).

Examples: Decide whether or not Tim should be found guilty. Decide whether Tim should be sent home or to jail. Get Tim to confess. To see what the judge should do to Tim. He protects him if he's innocent. 
2. Q2: While he is with his lawyer, what is Tim supposed to do?

2 points: Responses clearly indicating a helping and trustful relationship. Responses which imply mere compliance are not given 2 points, but are scored 1 or 0 (unless elaboration by individual places the response in the 2-point category).

Examples: To help the lawyer. To tell the lawyer the truth about everything. Trust him and do what the lawyer thinks is best. Do what he says because he's on Tim's side. Tell him what he did and why. Cooperate with him. Answer his questions.

1 point: Responses stating mere passive compliance. $O R$

Examples: Do what the lawyer says. Listen to instructions. Listen to what the lawyer is saying.

References simply to verbalization.

Examples: Talk to him. Discuss things. Ask him questions about what's happening.

0 points: Responses indicating the need for silence, caution, mistrust or strong inhibition of one's own behavior.

Examples: Speak only when spoken to. Don't run away. Keep quiet about what he did. Don't confess to anything. Keep his mouth shut. Plead the fifth. Behave himself.

3. Q3: What is the main thing that Tim's lawyer will be talking to Tim about?

2 points: Providing information or advice regarding future events in Interrogation or other court-related processes. $O R$

Examples: What is going to happen. What to say. What he can do to help him. What to do, when to do it, and how.

Emphasis on obtaining Tim's view of the alleged offenses.

Examples: If he really did it or not. How the crime happened. What it was that he did. Why he did it.

1 point: Moralistic questioning, or less important but still relevant topics.

Examples: Why what he did was wrong. When the hearing date will be. How long he'll be in jail.

0 points: Accusatory statement by lawyer; also, information or discussion that is not directly related to alleged offense or to police or court procedures.

Examples: He shouldn't have done it and he will pay for it. That he should try to do better in school. That he is a failure. About his problems at home (or other counseling topics).

4. Q4: Imagine that Tim's lawyer is saying: "I want you to tell me exactly what you did and tell me the truth about what happened." Then Tim tells him that he did the crime. Why would the lawyer want to know that?

2 points: Lawyer is seeking information to assist in Tim's defense.

Examples: So he can help Tim out better. So he can build a good case. So he can help Tim beat the rap. To get Tim's side of the story and help him better.

1 point: To get truthful information, but no mention of assistance nor of judgment.

Examples: To get the facts. To find out if Tim did it. To get all the information he can.

0 points: To make judgments which are contrary to the role of an advocate, or to assist the court in learning of Tim's guilt. 
Examples: To tell the judge about it. To decide whether Tim should go to a jail or someplace. To decide whether Tim should be found guilty. So he can get him to give himself up.

\section{Card 3: Greg's Interrogation}

1. Q1: Finish the sentence. If Greg decides to tell the police about what he did, then the things that Greg says

2 points: A relationship is made between what is said and later court hearing or record.

Examples: Can be used against him in court. Will get him into trouble at court time. Can turn against him later in court. Will be told to the judge later on. Will go into his record. Will get him into jail and they will set a court date.

1 point: Idea that what he says can cause him trouble, but without specification or how or when.

Examples: Will be held against him. Can get him into trouble. Will get him into detention.

0 points: Responses irrelevant to the essential issues of later use of confession; also, failure to recognize importance of confession.

Examples: Will be true. Won't matter anyway. He will tell the policemen.

2. Q2: If Greg decides not to talk, what is the most important thing the police are supposed to do?

2 points: Any action that is not coercive, and represents a legally sanctioned and probable response by police involving no further questioning.

Examples: Do nothing. Leave him be. Don't question him. Get him a lawyer. Phone his parents or guardian. Let him go.

1 point: Responses which are not clearly coercive, but which emphasize detainment.

Examples: Hold him until his court hearing. Take him to jail.

0 points: Further questioning; also, don't know.

Examples: Remind him of his rights. Try to make him talk without forcing him. Tell him the trouble he can get into for hiding the truth. Asking him why he won't talk.

3. Q3: If Greg says that he doesn't want to talk, but the police tell him he has to talk, what should happen then?

2 points: Recognition of the illegality of the police action, or the falseness of their claim. Decision to talk or not to talk is not relevant to scoring 2 points. $O R$

Examples: They will be lying because he doesn't have to. They would be going against his rights. It still doesn't mean that he has to talk. Greg can tell them he doesn't have to talk. They are wrong. He'll know that he doesn't have to really. He'll talk even though he knows he doesn't have to. They shouldn't be saying that. They will have to let him go. Stop asking him questions and put him back in jail. Nothing should happen, but they will probably beat him up. He doesn't have to talk until he goes to court.

Seeking intervention by anyone who could potentially be an advocate.

Examples: Greg should ask to talk to his lawyer. He'll ask to see a social worker first. He will tell them he wants to talk to his parents or guardian now.

1 point: Responses primarily refer to Greg's decision, without offering either a reason for the decision, or recognition of illegality of police action.

Responses indicating that the youth will not or should not talk, but without recognition of impropriety of the police statement. $O R$ 
Examples: Greg still won't talk. He shouldn't if he's smart.

Responses indicating simply that Greg will talk, or that he may or may not talk (ambivalent responses). $O R$

Examples: Greg will tell them the truth. He would talk and get himself messed up. He will get scared and talk. He might talk. He will rebel or he might tell everything. He'll have to talk.

Responses which could represent attempt to subvert police demands. $O R$

Examples: Then Greg will probably tell the police a lie. He will make up something. $\mathrm{H}$ would tell them something but not much. He would go into the bathroom and eat soap.

Lock him up (without further explanation).

0 points: Responses in which youth does or does not decide to talk solely on the basis of the importance of avoiding future negative consequences, without any sign of recognition of the inappropriateness of the police demand. $O R$

Examples: Greg will talk because he doesn't want to get beat. He still won't talk because it would get his friends into trouble. He'll talk so he can get out of going to jail.

Other responses showing no recognition of impropriety of police demands.

Examples: Greg will wish he had never stole the money. Greg will be sad. The police will start to ask him questions.

D. Card 4: Greg's Court Hearing

1. Q1: If Greg's lawyer did just what he is supposed to do here in court, how would Greg be feeling?

2 points: Affect or attitude reflecting knowledge of lawyer's intended role as advocate; generally, positive effect or "mixed" responses.

Examples: Good, because he's going to get out. Relieved. Good. Better. Like there is some hope. Like things are ok. Like the lawyer is doing the best he can. Satisfied. Like he's got a fair deal. Good because he's trying to help, bad because some things he's saying could hurt. Happy if the lawyer says good things, but bad because some things may not be right.

1 point: Bad or negative outcome, without reference to the lawyer's role.

Examples: Probably feeling bad, because they might not let him go. Worried, the judge might go hard on him. Guess he's feeling bad, with all those people around him asking questions.

0 points: Generally negative affect.

Examples: Mad. Like a criminal. Scared. Miserable. Like there is not hope. Guilty. Sad because some of what the lawyer said was bad. Upset because the lawyer told what he had done.

2. Q2: If the judge finds out that Greg wouldn't talk to the police, then what should happen?

2 points: Any response that does not constitute a penalty for assuming one's right to silence, nor suggests prejudice against the individual because of it.

Examples: Nothing bad will happen. Go on with the hearing. The judge will listen to what everybody else has to say. Greg can always talk to his lawyer. The judge will have to let him go.

1 point: Inquiry regarding silence itself.

Examples: Ask Greg why he wouldn't talk. The judge might ask Greg if he still wishes to say nothing. 
0 point: Any response indicating prejudice regarding motive for maintaining silence, increased penalty, reflection on probable guilt, or asking individual to give information about the alleged offense.

Examples: Make punishment worse. Judge will say if he wasn't guilty, he should have nothing to hide. Think he's guilty. Think that something is wrong. Make him talk now. Judge will ask Greg what did happen. Judge will send him back to jail. Judge will send him somewhere.

3. Q3: Greg did not tell the police anything about what he did. Here in court, if he is asked to talk about what he did that was wrong, will he have to talk?

2 points: Answer of "No."

1 point: Answer of "Yes, if his lawyer says it is best to."

0 points: Answer of "Yes," "I don't know," or "Only if the judge tells him to." 
STATISTICAL APPENDIX

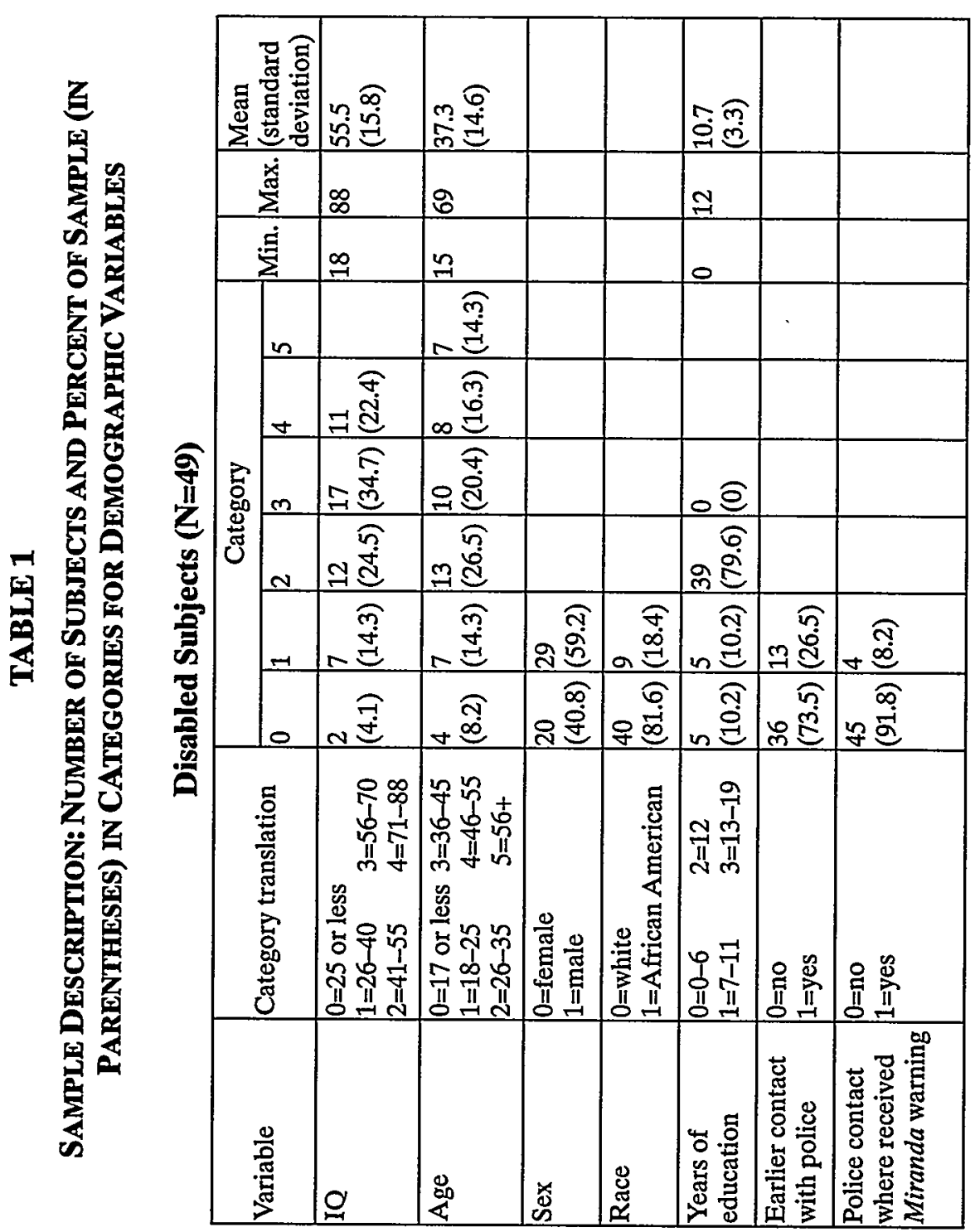




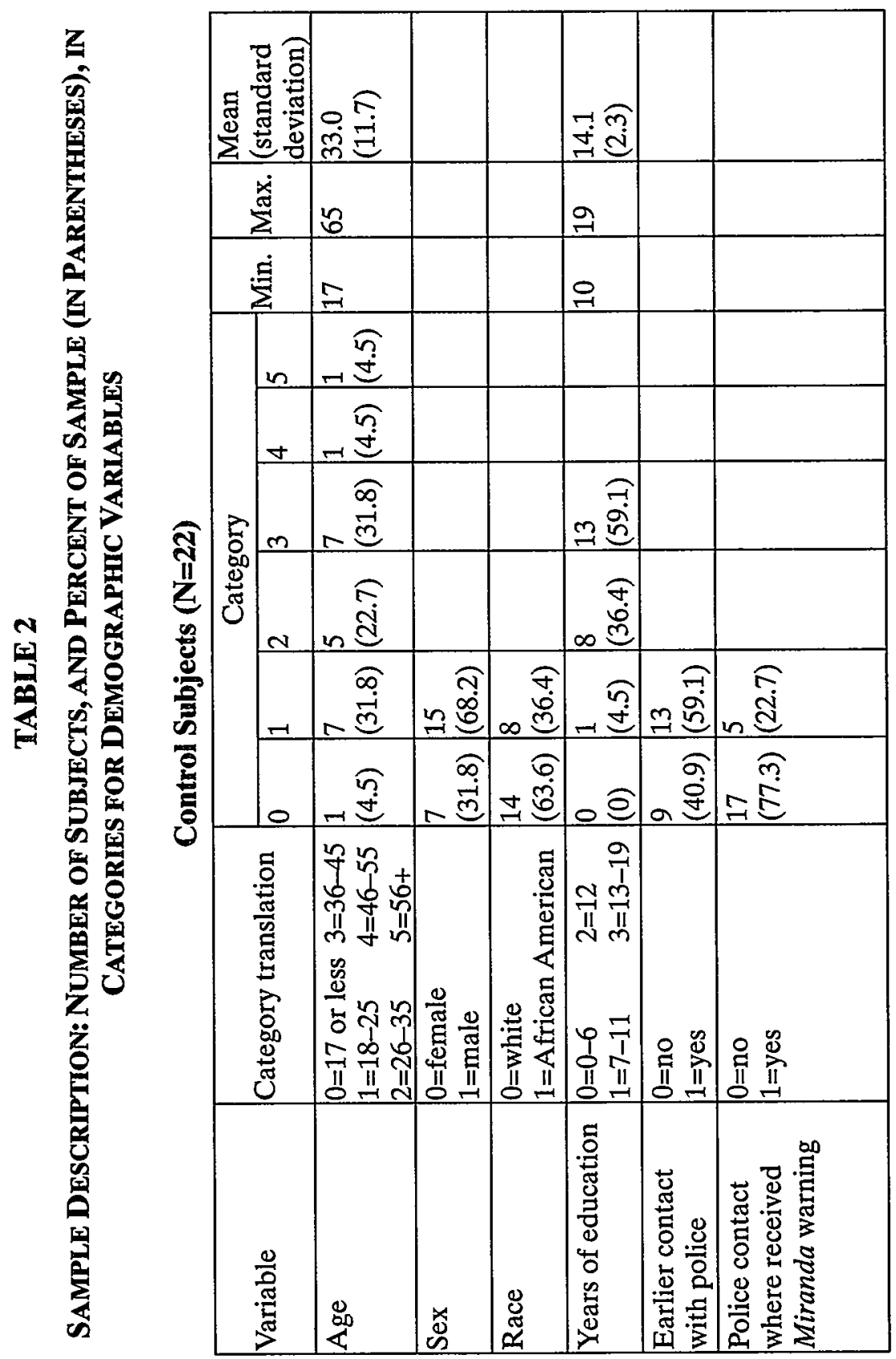


TABLE 3

VOCABULARY TEST

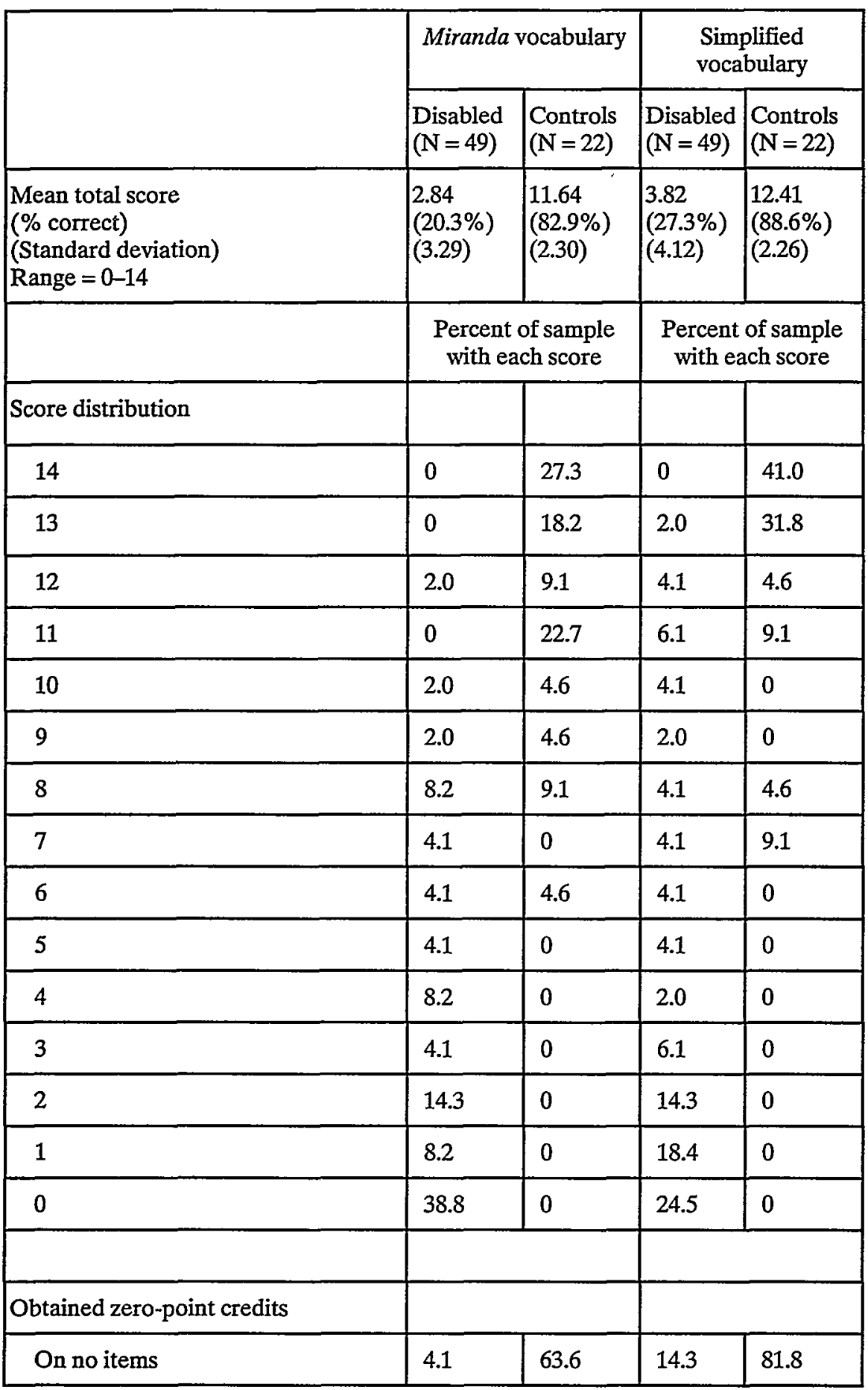




\begin{tabular}{|c|c|c|c|c|}
\hline On one item & 8.2 & 22.7 & 2.0 & 4.6 \\
\hline On two items & 4.1 & 4.6 & 10.2 & 13.6 \\
\hline On three items & 4.1 & 9.1 & 8.2 & 0 \\
\hline On four items & 4.1 & 0 & 6.1 & 0 \\
\hline On five items & 16.3 & 0 & 10.2 & 0 \\
\hline On six items & 12.2 & 0 & 24.5 & 0 \\
\hline On seven items & 38.8 & 0 & 24.5 & 0 \\
\hline On one or more items & 95.9 & 36.4 & 85.7 & 18.2 \\
\hline \multicolumn{5}{|l|}{$\begin{array}{l}\text { Adequate (2-point) response } \\
\text { (Simplified term in parentheses) }\end{array}$} \\
\hline I. Consult (Seek advice) & 4.1 & 54.6 & 18.4 & 86.4 \\
\hline II. Attorney (Lawyer) & 28.6 & 95.5 & 30.6 & 95.5 \\
\hline III. Intèrrogation (Questioning) & 8.2 & 90.9 & 14.3 & 77.3 \\
\hline IV.Appoint (Choose) & 16.3 & 72.7 & 18.4 & 95.5 \\
\hline V. Entitled (Deserve) & 10.2 & 100 & 14.3 & 72.7 \\
\hline VI. Right (Choice) & 10.2 & 59.1 & 8.2 & 54.6 \\
\hline VII. Statement (Your story) & 6.1 & 50.0 & 18.4 & 90.9 \\
\hline \multicolumn{5}{|l|}{$\begin{array}{l}\text { Inadequate (0-point) response } \\
\text { (Simplified term in parentheses) }\end{array}$} \\
\hline I. Consult (Seek advice) & 73.5 & 13.6 & 69.4 & 4.6 \\
\hline II. Attorney (Lawyer) & 49.0 & 0 & 32.6 & 0 \\
\hline III. Interrogation (Questioning) & 87.8 & 9.1 & 57.1 & 9.1 \\
\hline IV. Appoint (Choose) & 75.5 & 18.2 & 75.5 & 0 \\
\hline V. Entitled (Deserve) & 77.6 & 0 & 79.6 & 18.2 \\
\hline VI. Right (Choice) & 69.4 & 9.1 & 63.3 & 0 \\
\hline VII. Statement (Your story) & 67.4 & 9.1 & 63.3 & 0 \\
\hline
\end{tabular}


TABLE 4

The Warnings Test SCORES, OVERALl Results

\begin{tabular}{|c|c|c|}
\hline & $\begin{array}{l}\text { Disabled } \\
(\mathrm{N}=49)\end{array}$ & $\begin{array}{l}\text { Controls } \\
(\mathrm{N}=22)\end{array}$ \\
\hline $\begin{array}{l}\text { Mean total number correct of all } 24 \\
\text { comparisons and questions (percent } \\
\text { correct) }\end{array}$ & $6.47(27.0 \%)$ & $21.50(89.6 \%)$ \\
\hline $\begin{array}{l}\text { Mean total number correct of } 12 \\
\text { comparisons (percent correct) }\end{array}$ & $1.37(11.4 \%)$ & $10.45(87.1 \%)$ \\
\hline \multirow{2}{*}{$\begin{array}{l}\text { Mean total number correct of } 12 \\
\text { questions (percent correct) }\end{array}$} & $5.10(42.5 \%)$ & $11.05(92.1 \%)$ \\
\hline & $\begin{array}{l}\text { Percent of sample } \\
\text { with each score. }\end{array}$ & $\begin{array}{l}\text { Percent of sample } \\
\text { with each score. }\end{array}$ \\
\hline \multicolumn{3}{|l|}{ Score distribution } \\
\hline $24-23$ & 0 & 59.1 \\
\hline $22-21$ & 0 & 13.6 \\
\hline $20-19$ & 2.0 & 13.6 \\
\hline $18-17$ & 0 & 4.5 \\
\hline $16-15$ & 4.1 & 4.5 \\
\hline 14-13 & 2.0 & 0 \\
\hline $12-11$ & 8.2 & 4.5 \\
\hline $10-9$ & 4.1 & 0 \\
\hline $8-7$ & 20.4 & 0 \\
\hline $6-5$ & 30.6 & 0 \\
\hline $4-3$ & 16.3 & 0 \\
\hline $2-1$ & 2.0 & 0 \\
\hline $\mathbf{0}$ & 10.2 & $\mathbf{0}$ \\
\hline
\end{tabular}


TABLE 5

RESULTS FOR FIRST MIRANDA SENTENCE:

"YOU DO NOT HAVE TO MAKE A STATEMENT AND

HAVE THE RIGHT TO REMAIN SILENT."

\begin{tabular}{|l|c|c|}
\hline & Disabled (N=49) & Controls (N=22) \\
\hline $\begin{array}{l}\text { All 6 comparisons and questions } \\
\text { Mean number correct (percent correct) }\end{array}$ & $1.33(22.2 \%)$ & $5.22(87.0 \%)$ \\
\hline $\begin{array}{l}\text { 3 comparisons } \\
\text { Mean number correct (percent correct) }\end{array}$ & $0.29(9.7 \%)$ & $2.59(86.3 \%)$ \\
\hline $\begin{array}{l}\text { 3 questions } \\
\text { Mean number correct (percent correct) }\end{array}$ & $1.04(34.7 \%)$ & $2.64(88.0 \%)$ \\
\hline \begin{tabular}{l} 
Total number correct \\
\hline 5-6
\end{tabular} & Percent of sample & Percent of sample \\
with each score.
\end{tabular}


TABLE 6

RESULTS FOR SECOND MIRANDA SENTENCE:

"ANYTHING YOU SAY CAN AND WILL BE USED

AGAINST YOU IN A COURT OF LAW."

\begin{tabular}{|c|c|c|}
\hline & Disabled $(\mathrm{N}=49)$ & Controls $(\mathrm{N}=22)$ \\
\hline $\begin{array}{l}\text { All } 6 \text { comparisons and questions } \\
\text { Mean number correct (percent correct) }\end{array}$ & $1.84(30.7 \%)$ & $5.68(94.7 \%)$ \\
\hline $\begin{array}{l}3 \text { comparisons } \\
\text { Mean number correct (percent correct) }\end{array}$ & $0.31(10.3 \%)$ & $2.77(92.3 \%)$ \\
\hline $\begin{array}{l}3 \text { questions } \\
\text { Mean number correct (percent correct) }\end{array}$ & $1.53(51 \%)$ & $2.91(97.0 \%)$ \\
\hline Total number correct & $\begin{array}{l}\text { Percent of sample } \\
\text { with each score. }\end{array}$ & $\begin{array}{l}\text { Percent of sample } \\
\text { with each score. }\end{array}$ \\
\hline $5-6$ & 6.1 & 90.9 \\
\hline $3-4$ & 16.3 & 10.0 \\
\hline $1-2$ & 67.3 & 0 \\
\hline 0 & 10.2 & 0 \\
\hline $\begin{array}{l}\text { Fraction of subjects with correct answer } \\
\text { on comparison: "What you say might be } \\
\text { used to prove you guilty." }\end{array}$ & 12.2 & 95.5 \\
\hline $\begin{array}{l}\text { Fraction of subjects with correct answer } \\
\text { on question: "If you talk to the police, } \\
\text { can they use your story to get you in } \\
\text { trouble?" }\end{array}$ & 36.7 & 95.5 \\
\hline
\end{tabular}


TABLE 7

RESULTS FOR THE THIRD MIRANDA SENTENCE: "YOU ARE ENTTTLED TO CONSULT WITH AN ATTORNEY BEFORE INTERROGATION AND TO HAVE AN ATTORNEY PRESENT AT THE TIME OF THE INTERROGATION."

\begin{tabular}{|c|c|c|}
\hline & Disabled $(\mathrm{N}=49)$ & Controls $(\mathrm{N}=22)$ \\
\hline $\begin{array}{l}\text { All } 6 \text { comparisons and questions } \\
\text { Mean number correct (percent correct) }\end{array}$ & $1.84(30.7 \%)$ & $5.18(86.3 \%)$ \\
\hline $\begin{array}{l}3 \text { comparisons } \\
\text { Mean number correct (percent correct) }\end{array}$ & $0.33(11.0 \%)$ & $2.59(86.3 \%)$ \\
\hline $\begin{array}{l}3 \text { questions } \\
\text { Mean number correct (percent correct) }\end{array}$ & $1.51(50.3 \%)$ & $2.59(86.3 \%)$ \\
\hline Total number correct & $\begin{array}{l}\text { Percent of sample } \\
\text { with each score. }\end{array}$ & $\begin{array}{l}\text { Percent of sample } \\
\text { with each score. }\end{array}$ \\
\hline $5-6$ & 4.1 & 86.4 \\
\hline $3-4$ & 24.5 & 4.5 \\
\hline $1-2$ & 51.0 & 9.1 \\
\hline 0 & 20.4 & 0 \\
\hline $\begin{array}{l}\text { Fraction of subjects with correct answer on } \\
\text { comparison: "You can have a lawyer now } \\
\text { if you ask for one." }\end{array}$ & 10.2 & 95.5 \\
\hline $\begin{array}{l}\text { Fraction of subjects with correct answer on } \\
\text { question: "Can you get a lawyer before } \\
\text { you talk to the police if you want one?" }\end{array}$ & 71.4 & 95.5 \\
\hline
\end{tabular}


TABLE 8

RESULTS FOR FOURTH MIRANDA SENTENCE: "IF YOU CANNOT AFFORD AN ATTORNEY, ONE WILL BE APPOINTED FOR YOU."

\begin{tabular}{|c|c|c|}
\hline & Disabled (N=49) & Controls $(\mathrm{N}=22)$ \\
\hline $\begin{array}{l}\text { All } 6 \text { comparisons and questions } \\
\text { Mean number correct (percent correct) }\end{array}$ & $1.47(24.5 \%)$ & $5.41(90.2 \%)$ \\
\hline $\begin{array}{l}3 \text { comparisons } \\
\text { Mean number correct (percent correct) }\end{array}$ & $0.45(15.0 \%)$ & $2.50(83.3 \%)$ \\
\hline $\begin{array}{l}3 \text { questions } \\
\text { Mean number correct (percent correct) }\end{array}$ & $1.02(34.0 \%)$ & $2.91(97.0 \%)$ \\
\hline Total number correct & $\begin{array}{l}\text { Percent of sample } \\
\text { with each score. }\end{array}$ & $\begin{array}{l}\text { Percent of sample } \\
\text { with each score. }\end{array}$ \\
\hline $5-6$ & 4.1 & 95.5 \\
\hline $3-4$ & 16.3 & 4.5 \\
\hline $1-2$ & 49.0 & 0 \\
\hline 0 & 30.6 & 0 \\
\hline $\begin{array}{l}\text { Fraction of subjects with correct answer } \\
\text { on comparison: "The court will give you a } \\
\text { lawyer free if you don't have the money } \\
\text { to pay for one." }\end{array}$ & 18.4 & 91.0 \\
\hline $\begin{array}{l}\text { Fraction of subjects with correct answer } \\
\text { on question: "If you are poor, can you get } \\
\text { an attorney?" }\end{array}$ & 38.8 & 100 \\
\hline $\begin{array}{l}\text { Fraction of subjects with correct answer } \\
\text { on question: "Do you have to have } \\
\text { money to get an attorney?" }\end{array}$ & 26.5 & 100 \\
\hline
\end{tabular}


TABLE 9

SCORES ON MIRANDA CONCEPTS TEST PART I: NATURE OF INTERROGATION

\begin{tabular}{|l|l|l|}
\hline \multicolumn{1}{|c|}{ Variable } & $\begin{array}{l}\text { Disabled } \\
(\mathrm{N}=49)\end{array}$ & $\begin{array}{l}\text { Controls } \\
(\mathrm{N}=22)\end{array}$ \\
\hline $\begin{array}{l}\text { Mean score (percent correct) } \\
\text { (standard deviation) } \\
\text { Range 0-10 }\end{array}$ & $\begin{array}{l}6.18(61.8 \%) \\
(3.79))\end{array}$ & $\begin{array}{l}9.23(92.3 \%) \\
(1.02)\end{array}$ \\
\hline Percent of adequate (2-point) responses on items & & \\
\hline 1. Purpose of interrogation & 46.9 & 81.8 \\
\hline 2. Crime suspected & 67.4 & 95.5 \\
\hline 3. Information sought by police & 44.9 & 77.3 \\
\hline 4. Police feelings/attitude & 57.1 & 81.8 \\
\hline 5. Suspect feelings/attitude & 69.4 & 90.9 \\
\hline & & \\
\hline Percent of inadequate (0-point) responses on items & & \\
\hline 1. Purpose of interrogation & 30.6 & 4.6 \\
\hline 2. Crime suspected & 30.6 & 4.6 \\
\hline 3. Information sought by police & 36.7 & 0 \\
\hline 4. Police feelings/attitude & 40.8 & 0 \\
\hline 5. Suspect feelings/attitude & 28.6 & 0 \\
\hline
\end{tabular}

TABLE $\mathbb{1 0}$

SCORES ON MIRANDA CONCEPTS TEST PART III: Right TO COUNSEL

\begin{tabular}{|l|l|l|}
\hline \multicolumn{1}{|c|}{ Variable } & $\begin{array}{l}\text { Disabled } \\
(\mathrm{N}=49)\end{array}$ & $\begin{array}{l}\text { Controls } \\
(\mathrm{N}=22)\end{array}$ \\
\hline $\begin{array}{l}\text { Mean score (percent correct) } \\
\text { (standard deviation) } \\
\text { Range 0-10 }\end{array}$ & $\begin{array}{l}3.47(34.7 \%) \\
(2.25)\end{array}$ & $\begin{array}{l}9.32(93.2 \%) \\
(.99)\end{array}$ \\
\hline Percent of adequate (2-point) responses on items & & \\
\hline 1. Lawyer's defense role & 22.5 & 81.8 \\
\hline 2. Client's role & 26.5 & 81.8 \\
\hline 3. Information sought by lawyer & 24.5 & 90.9 \\
\hline 4. Reason to seek truth & 16.3 & 86.4 \\
\hline 5. Lawyer's defense potential & 28.6 & 95.5 \\
\hline & & \\
\hline Percent of inadequate (0-point) responses on items & & \\
\hline 1. Lawyer's defense role & 53.1 & 0 \\
\hline 2. Client's & 32.7 & 0 \\
\hline 3. Information sought by lawyer & 53.1 & 0 \\
\hline 4. Reason to seek & 71.4 & 4.6 \\
\hline 5. Lawyer's defense & 61.2 & 0 \\
\hline
\end{tabular}


TABLE 11

SCORES ON MIRANDA ConCEPTS TEST PART III: RIGHT To SILENCE

\begin{tabular}{|l|c|c|}
\hline Variable & Disabled (N=49) & Controls (N=22) \\
\hline $\begin{array}{l}\text { Mean score (percent correct) } \\
\text { (standard deviation) } \\
\text { Range 0-10 }\end{array}$ & $\begin{array}{l}1.78(17.8 \%) \\
(2.02)\end{array}$ & $\begin{array}{l}7.45(74.5 \%) \\
(2.42)\end{array}$ \\
\hline $\begin{array}{l}\text { Percent of adequate (2-point) responses } \\
\text { on items }\end{array}$ & & \\
\hline 1. Use of confession & 26.5 & 90.9 \\
\hline 2. Freedom from pressure & 8.2 & 81.8 \\
\hline 3. Right is irrevocable regarding police & 12.2 & 77.3 \\
\hline 4. No penalty for asserting right & 2.0 & 72.7 \\
\hline 5. Right is irrevocable regarding judge & 18.4 & 40.9 \\
\hline \hline $\begin{array}{l}\text { Percent of inadequate (0-point) } \\
\text { responses on items }\end{array}$ & & \\
\hline 1. Use of confession & 61.2 & 0 \\
\hline 2. Freedom from pressure & 65.3 & 18.2 \\
\hline 3. Right is irrevocable regarding police & 83.7 & 13.6 \\
\hline 4. No penalty for asserting right & 98.0 & 27.3 \\
\hline 5. Right is irrevocable regarding judge & 81.6 & 59.1 \\
\hline
\end{tabular}

TABLE 12

\section{REgRESSION RESULTS: TOTAL SCORES ON ALL TESTS}

\begin{tabular}{|c|c|c|c|}
\hline \multicolumn{4}{|c|}{$\begin{array}{l}\text { Dependent variable: percent correct on all tests. } \\
\text { Ordinary least squares estimation, reporting: Coefficient ( } \mathrm{T} \text { statistic) }\end{array}$} \\
\hline & $\begin{array}{l}\text { Column } 1 \\
\text { All Subjects }\end{array}$ & $\begin{array}{l}\text { Column } 2 \\
\text { Disabled Subjects }\end{array}$ & $\begin{array}{l}\text { Column } 3 \\
\text { Controls }\end{array}$ \\
\hline Subject is disabled: IQ below 90 & $\begin{array}{l}-.520 \\
(-9.287) * *\end{array}$ & & \\
\hline IQ & & $\begin{array}{l}.008 \\
(5.014)^{* * *}\end{array}$ & \\
\hline Age & 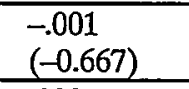 & $\begin{array}{l}-.001 \\
(-0.708)\end{array}$ & $\begin{array}{l}-.001 \\
(-.321) \\
\end{array}$ \\
\hline Years of education completed & .008 & .003 & .024 \\
\hline Earlier contact with police & .104 & .121 & .006 \\
\hline $\begin{array}{l}\text { Earlier police contact and } \\
\text { received Miranda warning }\end{array}$ & .001 & $\begin{array}{l}.060 \\
(0.551) \\
\end{array}$ & .042 \\
\hline Race & $\begin{array}{l}-.0490 \\
(-0.867)\end{array}$ & $\begin{array}{l}.053 \\
(0.778)\end{array}$ & $\begin{array}{l}-.051 \\
(-.770)\end{array}$ \\
\hline Sex & $\begin{array}{l}-.014 \\
(-0.314)\end{array}$ & $\begin{array}{l}.029 \\
(0.551)\end{array}$ & $\begin{array}{l}-.027 \\
(-.420)\end{array}$ \\
\hline Constant & $\begin{array}{l}.767 \\
(5.245)^{* *}\end{array}$ & $\begin{array}{l}.180 \\
(-1.171)\end{array}$ & $\begin{array}{l}.584 \\
(2.549) * *\end{array}$ \\
\hline Number of subjects & 71 & 49 & 22 \\
\hline Adjusted $\mathrm{R}^{2}$ & .703 & .388 & .060 \\
\hline
\end{tabular}

** and bold type indicate significance at $5 \%$ level. 
TABLE $\mathbb{1 3}$

REGRESSION RESULTS:

MIRANDA VOCABULARY TEST

\begin{tabular}{|c|c|c|c|}
\hline \multicolumn{4}{|c|}{$\begin{array}{l}\text { Dependent variable: total score out of } 14 \text { possible on the Miranda Vocabulary Test } \\
\text { Ordinary least squares estimation, reporting: Coefficient (T statistic) }\end{array}$} \\
\hline & $\begin{array}{l}\text { Column } 1 \\
\text { All subjects }\end{array}$ & $\begin{array}{l}\text { Column } 2 \\
\text { Disabled subjects }\end{array}$ & $\begin{array}{l}\text { Column } 3 \\
\text { Controls }\end{array}$ \\
\hline $\begin{array}{l}\text { Subject is disabled: IQ } \\
\text { below } 90\end{array}$ & $\begin{array}{l}-8.403 \\
(-8.665) * *\end{array}$ & & \\
\hline IQ & & $\begin{array}{l}.087 \\
(2.803)^{* *}\end{array}$ & \\
\hline Age & $\begin{array}{l}-.018 \\
(-.629)\end{array}$ & $\begin{array}{l}-.014 \\
(-.391)\end{array}$ & $\begin{array}{l}-.045 \\
(-1.217)\end{array}$ \\
\hline $\begin{array}{l}\text { Years of education } \\
\text { completed }\end{array}$ & $\begin{array}{l}.165 \\
(1.225)\end{array}$ & $\begin{array}{l}.108 \\
(.705)\end{array}$ & $\begin{array}{l}.459 \\
(1.879)^{*}\end{array}$ \\
\hline Earlier contact with police & $\begin{array}{l}-.294 \\
(-.325)\end{array}$ & $\begin{array}{l}.064 \\
(.052)\end{array}$ & $\begin{array}{l}-1.327 \\
(-1.245)\end{array}$ \\
\hline $\begin{array}{l}\text { Earlier police contact and } \\
\text { received Miranda warning }\end{array}$ & $\begin{array}{l}.363 \\
(.269)\end{array}$ & $\begin{array}{l}.823 \\
(.372)\end{array}$ & $\begin{array}{l}1.610 \\
(1.279)\end{array}$ \\
\hline Race & $\begin{array}{l}-1.129 \\
(-1.153)\end{array}$ & $\begin{array}{l}.106 \\
(.076)\end{array}$ & $\begin{array}{l}-1.237 \\
(-1.107)\end{array}$ \\
\hline Sex & $\begin{array}{l}.132 \\
(.175)\end{array}$ & $\begin{array}{l}.876 \\
(.887)\end{array}$ & $\begin{array}{l}-.959 \\
(-.901)\end{array}$ \\
\hline Constant & $\begin{array}{l}10.316 \\
(4.064) * *\end{array}$ & $\begin{array}{l}-3.314 \\
(-1.060)\end{array}$ & $\begin{array}{l}8.178 \\
(2.129)^{* * *}\end{array}$ \\
\hline Number of subjects & 71 & 49 & 22 \\
\hline Pseudo $\mathrm{R}^{2}$, adjusted $\mathrm{R}^{2}$ & .645 & .075 & .308 \\
\hline
\end{tabular}

** and bold type: significance at $5 \%$ level. * and bold type: significance at $10 \%$ level. 
TABLE 14

REGRESSION RESULTS: UNDERSTANDING OF MIRANDA WARNINGS TEST

\begin{tabular}{|c|c|c|c|}
\hline \multicolumn{4}{|c|}{$\begin{array}{l}\text { Dependent variable: total score out of } 24 \text { possible on Understanding of Miranda } \\
\text { Warnings Test. } \\
\text { Ordinary Least Squares estimation, reporting: Coefficient (T statistic) }\end{array}$} \\
\hline & \begin{tabular}{|l} 
Column 1 \\
All subjects
\end{tabular} & $\begin{array}{l}\text { Column } 2 \\
\text { Disabled subjects }\end{array}$ & \begin{tabular}{|l} 
Column 3 \\
Controls
\end{tabular} \\
\hline Subject is disabled: IQ below 90 & $\begin{array}{l}-14.261 \\
(-11.677)^{* * *}\end{array}$ & & \\
\hline IQ & & $\begin{array}{l}.121 \\
(\mathbf{3 . 2 7 9}) * *\end{array}$ & \\
\hline Age & $\begin{array}{l}-.006 \\
(-.180)\end{array}$ & $\begin{array}{l}.001 \\
(.023)\end{array}$ & $\begin{array}{l}-.005 \\
(-.090)\end{array}$ \\
\hline Years of education completed & $\begin{array}{l}.083 \\
.(.492)\end{array}$ & $\begin{array}{l}.021 \\
(.114)\end{array}$ & $\begin{array}{l}.333 \\
(.896)\end{array}$ \\
\hline Earlier contact with police & $\begin{array}{l}2.735 \\
(2.404) * * *\end{array}$ & $\begin{array}{l}2.494 \\
\text { (1.713)* }\end{array}$ & $\begin{array}{l}2.119 \\
(1.305)\end{array}$ \\
\hline $\begin{array}{l}\text { Earlier police contact and } \\
\text { received Miranda warning }\end{array}$ & $\begin{array}{l}-1.190 \\
(-.698)\end{array}$ & $\begin{array}{l}-2.092 \\
(-.790)\end{array}$ & $\begin{array}{l}.078 \\
(.041)\end{array}$ \\
\hline Race & $\begin{array}{l}-1.215 \\
(-.984)\end{array}$ & $\begin{array}{l}1.702 \\
(1.024)\end{array}$ & $\begin{array}{l}-2.653 \\
(-1.558)\end{array}$ \\
\hline Sex & $\begin{array}{l}-.410 \\
(-.430)\end{array}$ & $\begin{array}{l}-.600 \\
(-.509)\end{array}$ & $\begin{array}{l}-.056 \\
(-.035)\end{array}$ \\
\hline Constant & $\begin{array}{l}19.914 \\
(6.229)^{* *}\end{array}$ & $\begin{array}{l}-1.095 \\
(-.293)\end{array}$ & $\begin{array}{l}16.704 \\
(2.855)^{* * *}\end{array}$ \\
\hline Number of subjects & 71 & 49 & 22 \\
\hline Adjusted $\mathbf{R}^{2}$ & .772 & .171 & .132 \\
\hline
\end{tabular}

** and bold type: significance at $5 \%$ level. * and bold type: significance at $10 \%$ level. 
TABLE 15

REGRESSION RESULTS:

INDIVIDUAL QUESTIONS ON THE WARNINGS TEST

\begin{tabular}{|c|c|c|c|c|}
\hline & \multicolumn{4}{|c|}{ Logistic Regression, reporting: Odds ratio (z statistic) } \\
\hline & $\begin{array}{l}\text { Column } 1 \\
\text { All subjects }\end{array}$ & $\begin{array}{l}\text { Column } 2 \\
\text { Disabled } \\
\text { subjects }\end{array}$ & $\begin{array}{l}\text { Column } 3 \\
\text { All subjects }\end{array}$ & $\begin{array}{l}\text { Column } 4 \\
\text { Disabled } \\
\text { subjects }\end{array}$ \\
\hline $\begin{array}{l}\text { Independent } \\
\text { variables }\end{array}$ & \multicolumn{2}{|c|}{$\begin{array}{l}\text { Dep. var.: Correct on "Do } \\
\text { you have to tell the police } \\
\text { what happened?" }\end{array}$} & \multicolumn{2}{|c|}{$\begin{array}{l}\text { Dep. var: Correct on "Do you } \\
\text { have to answer the police if they } \\
\text { ask you any questions?" }\end{array}$} \\
\hline $\begin{array}{l}\text { Subject is disabled: } \\
\text { IQ below } 90\end{array}$ & $\begin{array}{l}.010 \\
(-3.793)^{* *}\end{array}$ & & $\begin{array}{l}.052 \\
(-3.628) * *\end{array}$ & \\
\hline IQ & & $\begin{array}{l}1.019 \\
(0.648)\end{array}$ & & $\begin{array}{l}1.008 \\
(0.363)\end{array}$ \\
\hline Age & $\begin{array}{l}.996 \\
(-.166)\end{array}$ & $\begin{array}{l}1.007 \\
(.224)\end{array}$ & $\begin{array}{l}1.037 \\
(1.551)\end{array}$ & $\begin{array}{l}1.035 \\
(1.265)\end{array}$ \\
\hline $\begin{array}{l}\text { Years of education } \\
\text { completed }\end{array}$ & $\begin{array}{l}.942 \\
(-.538)\end{array}$ & $\begin{array}{l}.940 \\
(-.504)\end{array}$ & $\begin{array}{l}.902 \\
(-1.046)\end{array}$ & $\begin{array}{l}.888 \\
(-1.119)\end{array}$ \\
\hline $\begin{array}{l}\text { Earlier contact with } \\
\text { police }\end{array}$ & $\begin{array}{l}1.493 \\
(.476)\end{array}$ & $\begin{array}{l}.854 \\
(-.156)\end{array}$ & $\begin{array}{l}2.020 \\
(1.004)\end{array}$ & $\begin{array}{l}1.754 \\
(0.649)\end{array}$ \\
\hline $\begin{array}{l}\text { Earlier police contact } \\
\text { and received Miranda } \\
\text { warning }\end{array}$ & $\begin{array}{l}1.002 \\
(.002)\end{array}$ & $\begin{array}{l}.527 \\
(-.385)\end{array}$ & $\begin{array}{l}.774 \\
(-.226)\end{array}$ & $\begin{array}{l}.685 \\
(-0.248)\end{array}$ \\
\hline Race & $\begin{array}{l}1.119 \\
(.115\end{array}$ & $\begin{array}{l}2.933 \\
(1.013)\end{array}$ & $\begin{array}{l}.438 \\
(-1.017)\end{array}$ & $\begin{array}{l}1.258 \\
(0.243)\end{array}$ \\
\hline Sex & $\begin{array}{l}.579 \\
(-.760)\end{array}$ & $\begin{array}{l}.309 \\
(-1.435)\end{array}$ & $\begin{array}{l}1.092 \\
(.149)\end{array}$ & $\begin{array}{l}.0912 \\
(-0.125)\end{array}$ \\
\hline Number of subjects & 71 & 49 & 71 & 49 \\
\hline
\end{tabular}

** and bold type: significance at $5 \%$ level. 
TABLE 16

REGRESSION RESULTS: CONCEPTS TEST

\begin{tabular}{|c|c|c|c|c|}
\hline & \multicolumn{2}{|c|}{$\begin{array}{l}\text { Ordinary Least Squares } \\
\text { estimation, reporting: } \\
\text { Coefficient (T statistic) }\end{array}$} & \multicolumn{2}{|c|}{$\begin{array}{l}\text { Logistic Regression, } \\
\text { reporting: Odds ratio (z } \\
\text { statistic) }\end{array}$} \\
\hline & $\begin{array}{l}\text { Column } 1 \\
\text { All subjects }\end{array}$ & $\begin{array}{l}\text { Column } 2 \\
\text { Disabled } \\
\text { subjects }\end{array}$ & \begin{tabular}{|l} 
Column 3 \\
All subjects
\end{tabular} & $\begin{array}{l}\text { Column } 4 \\
\text { All subjects }\end{array}$ \\
\hline Independent variables & \multicolumn{2}{|c|}{$\begin{array}{l}\text { Dep. var.: Total score out of } \\
30 \text { points on Concepts Test. }\end{array}$} & \multicolumn{2}{|c|}{$\begin{array}{l}\text { Dep. var.: Correct on } \\
\text { whether judge can force } \\
\text { defendant to testify. }\end{array}$} \\
\hline $\begin{array}{l}\text { Subject is disabled: IQ } \\
\text { below } 90\end{array}$ & $\begin{array}{l}-\mathbf{1 1 . 9 3 3} \\
(-\mathbf{5 . 8 3 0}) * *\end{array}$ & & $\begin{array}{l}.369 \\
(-1.250)\end{array}$ & 。 \\
\hline IQ & & \begin{tabular}{|l}
.306 \\
$(5.890) * *$
\end{tabular} & & $\begin{array}{l}1.018 \\
(.672)\end{array}$ \\
\hline Age & $\begin{array}{l}-.009 \\
(-.145)\end{array}$ & $\begin{array}{l}-.009 \\
(-.141)\end{array}$ & $\left(\begin{array}{l}1.003 \\
(.120)\end{array}\right.$ & $\begin{array}{l}1.002 \\
(.046)\end{array}$ \\
\hline $\begin{array}{l}\text { Years of education } \\
\text { completed }\end{array}$ & \begin{tabular}{|l}
.275 \\
$. .968)$
\end{tabular} & $\begin{array}{l}.132 \\
(.512)\end{array}$ & $\begin{array}{l}1.018 \\
(.166)\end{array}$ & $\begin{array}{l}.995 \\
(-.041)\end{array}$ \\
\hline Earlier contact with police & \begin{tabular}{|l}
5.165 \\
$(2.709) * *$
\end{tabular} & \begin{tabular}{|l|}
6.079 \\
$(2.978) * * *$
\end{tabular} & $\begin{array}{l}1.333 \\
(.398)\end{array}$ & $\begin{array}{l}2.277 \\
(.771)\end{array}$ \\
\hline $\begin{array}{l}\text { Earlier police contact and } \\
\text { received Miranda warning }\end{array}$ & $\begin{array}{l}.601 \\
(.210)\end{array}$ & $\begin{array}{l}3.040 \\
(.819)\end{array}$ & $\frac{.208}{(-1.394)}$ & $\begin{array}{l}.345 \\
(-.589)\end{array}$ \\
\hline Race & $\mid \begin{array}{l}-.013 \\
(-.006)\end{array}$ & $\begin{array}{l}3.588 \\
(1.539)\end{array}$ & $\mid \begin{array}{l}5.147 \\
(2.186)^{* * * a}\end{array}$ & 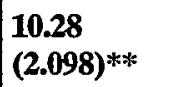 \\
\hline Sex & $\begin{array}{l}-.994 \\
(-.622)\end{array}$ & $\begin{array}{l}.760 \\
(.459)\end{array}$ & $\mid \begin{array}{l}1.481 \\
(.613)\end{array}$ & $\begin{array}{l}4.395 \\
(1.431)\end{array}$ \\
\hline Constant & $\begin{array}{l}19.905 \\
(3.715)^{* *}\end{array}$ & $\mid \begin{array}{l}-9.917 \\
(-1.891)^{* * *}\end{array}$ & & \\
\hline Number of subjects & 71 & 49 & $\mid 71$ & 49 \\
\hline Adjusted $\mathrm{R}^{2}$ & .547 & .512 & & \\
\hline
\end{tabular}

*** and bold type: significance at $5 \%$ level. 
TABLE 17

REGRESSION RESULTS:

IMPROVEMENT ON SIMPLIFIED MIRANDA VOCABULARY TEST

Dependent variable: Difference in score on Miranda Vocabulary Test and Simplified Miranda Vocabulary Test.

Ordinary least squares estimation, reporting: Coefficient ( $T$ statistic)

\begin{tabular}{|c|c|c|c|}
\hline & $\begin{array}{l}\text { Column } 1 \\
\text { All subjects }\end{array}$ & $\begin{array}{l}\text { Column } 2 \\
\text { Disabled subjects }\end{array}$ & $\begin{array}{l}\text { Column } 3 \\
\text { Controls }\end{array}$ \\
\hline $\begin{array}{l}\text { Subject is disabled: IQ } \\
\text { below } 90\end{array}$ & $\begin{array}{l}.449 \\
(.637)\end{array}$ & & \\
\hline IQ & & $\begin{array}{l}.023 \\
(.968)\end{array}$ & \\
\hline Age & $\begin{array}{l}-.039 \\
(-1.876)^{* *}\end{array}$ & $\begin{array}{l}-.068 \\
(-2.432) * *\end{array}$ & $\begin{array}{l}.030 \\
(1.559)\end{array}$ \\
\hline $\begin{array}{l}\text { Years of education } \\
\text { completed }\end{array}$ & $\begin{array}{l}-.066 \\
(-.669)\end{array}$ & $\begin{array}{l}-.119 \\
(-1.009)\end{array}$ & $\begin{array}{l}-.028 \\
(-.218)\end{array}$ \\
\hline Earlier contact with police & $\begin{array}{l}1.230 \\
(1.870) * *\end{array}$ & $\begin{array}{l}1.239 \\
(1.332)\end{array}$ & $\begin{array}{l}.198 \\
(.352)\end{array}$ \\
\hline $\begin{array}{l}\text { Earlier police contact and } \\
\text { received Miranda warning }\end{array}$ & $\begin{array}{l}-.083 \\
(-.085)\end{array}$ & $\begin{array}{l}2.311 \\
(1.367)\end{array}$ & $\begin{array}{l}-1.684 \\
(-2.535)^{* * *}\end{array}$ \\
\hline Race & $\begin{array}{l}-.530 \\
(-.743)\end{array}$ & $\begin{array}{l}-1.153 \\
(-1.085)\end{array}$ & $\begin{array}{l}.643 \\
(1.090)\end{array}$ \\
\hline Sex & $\begin{array}{l}.018 \\
(.033)\end{array}$ & $\begin{array}{l}.476 \\
(.631)\end{array}$ & $\begin{array}{l}1.059 \\
(1.887)^{*}\end{array}$ \\
\hline Constant & $\begin{array}{l}2.455 \\
(1.329)\end{array}$ & $\begin{array}{l}2.918 \\
(1.221)\end{array}$ & $\begin{array}{l}-.525 \\
(-.259)\end{array}$ \\
\hline Number of subjects & 71 & 49 & 22 \\
\hline Adjusted $R^{2}$ & .018 & .119 & .172 \\
\hline
\end{tabular}

** and bold type: significance at $5 \%$ level. * and bold type: significance at $10 \%$ level. 